\title{
Gemma

\section{HOW TO ESCAPE FROM THE BLOODY CHAMBER: Strategies of Female Resistance in Folktales Matteo Cardillo}

\author{
Director principal \\ Prof. Gérardo Rodriguez Salas \\ Universidad de Granada
}

Directora de apoyo

Prof. Rita Monticelli

Alma Mater Studiorum - Università di Bologna

2018

Universidad

de Granada 
To my mother

A mi madre

A mia madre

Table of contents 


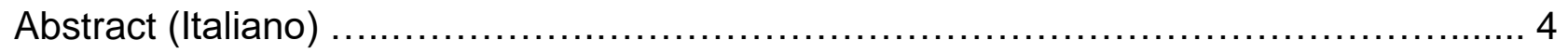

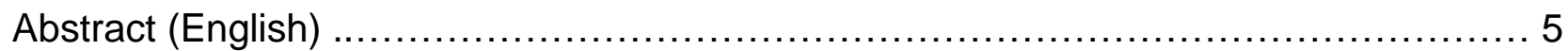

\section{Introduction}

1. Divine women: from martyrs to persecuted maidens .................................... 6

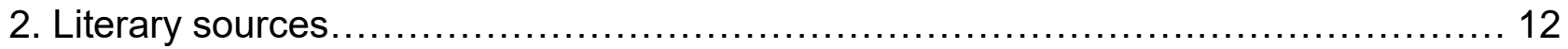

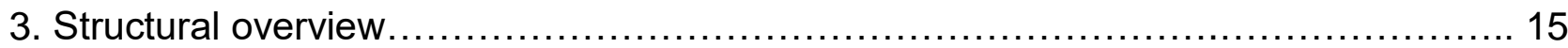

Chapter One. The forbidden room and other dishonored prohibitions: narrations of Bluebeard from Saint Triphine to Angela Carter

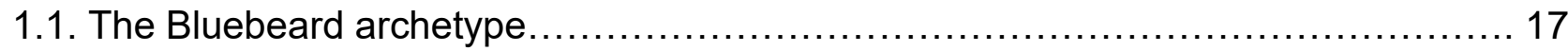

1.2. A young lady and her husband's keys.................................................. 18

1.3 "I only did what he knew I would": Angela Carter's The Bloody Chamber............... 33

1.4. Filling the blank page: the female subjectivity in The Bloody Chamber ............... 42

1.5. The Marquis and the Sultan: masculinity and Orientalism.......................... 45

Chapter Two. The Traffic in Maidens: female alliances, wicked women and elements of kinship in the patriarchal territory of folktales

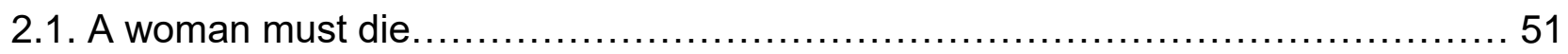

2.2. The Snow Child and the embodiment of male fantasies............................ 53

2.3. Runaway girls: tales of renegade daughters, incestuous men and chopped hands

65

Chapter Three. Body of evidence: women in male disguise and interferences in the homosocial sphere

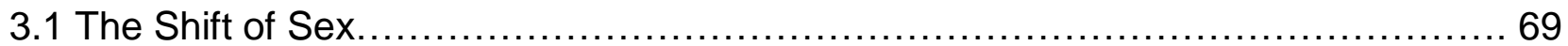

3.2 Costanza, Costanzo and the Three Crowns..................................... 71

3.3 The body of evidence: cross-dressing and battlefields.............................. 76 
Final considerations.

Bibliographical sources.

Webliography. 93

Special thanks. 94

\section{Abstract}


Perno centrale di questo dialogo critico sul racconto popolare è la soggettività femminile, e come essa venga resa funzionale alla reiterazione di logiche di potere e controllo eteronormativi che producono modelli sociali conservativi e inegualitari. Mediante la critica femminista e la rivisitazione postmoderna della tradizione della scrittrice Angela Carter, quello che ho tentato di fare è stato contestualizzare la costruzione stereotipata dei ruoli di genere, che permette alla cultura mainstream il controllo sui compiti sociali e sull'identità femminile. L'obiettivo è stato quello di determinare, negli archetipi fiabeschi presi in esame, secondo una visione critica attualizzante, quali strategie e tecniche vengono adottate dai personaggi femminili del racconto popolare per resistere alla violenza di genere e al dominio sciovinista, che sorveglia e monitora qualsiasi azione di tali donne, imbrigliate nella gabbia sociale della famiglia e della legge del Padre. Partendo da una approfondita lettura di The Bloody Chamber, ho esaminato le principali versioni dell'archetipo di tale tradizione, rivalorizzando il concetto di curiosità in Barbablu, sradicandolo dalla sua logica originale di peccato, biasimo e frivola violazione degli obblighi muliebri e conferendogli il valore di atto salvifico di autoconservazione. Nella struttura narrativa dei racconti aventi come argomento centrale la fuga della fanciulla perseguitata, osservo come questa stessa fuga della fanciulla da un conturbante contesto familiare venga a concludersi con un riassorbimento della stessa fanciulla nel ruolo per lei assegnato fin dal principio di moglie, figlia, madre e sorella devota. II terzo capitolo rappresenta uno studio del desiderio, maschile e femminile, nei racconti avente come matrice il crossdressing, il travestimento di una donna che adotta come strategia di resistenza la rinuncia all'identità femminile per abbracciare una performatività maschile. Le dinamiche sociali che la vedono protagonista la portano a una repressione del desiderio sessuale stesso, e a una repressione delle pulsioni omoerotiche verso la stessa.

\section{Abstract}


The rationale of this critical dialogue on the folktale is female subjectivity and how it is made functional to the reiteration of heteronormative logics of power and control that produce conservative and non-equalitarian social models. Through feminist criticism and the postmodern revision of the tradition by Angela Carter, I contextualize the stereotyped construction of gender roles that allows mainstream culture to control social assignments and female identity. The aim of this study is to determine in the fable archetypes considered for examination what strategies and techniques are adopted by the female characters of the folktales to withstand gender violence and chauvinist supremacy that supervises any action of such women, jailed in the social cage of family and the law of the Father. Taking a thorough reading of The Bloody Chamber as a starting point, I will examine the main versions of the archetype of such tradition, moving among the European tradition of the fairy tale, from Italy to France to Germany. Indeed, I re-evaluate in chapter one the concept of curiosity in Bluebeard, dislocating it from its original logic of sin, blame and frivolous violation of the feminine obligations, and conferring to it the value of survival. In the second chapter, while looking at the narrative structure of the stories having the escape of the persecuted young girl as the main topic, this very escape from a perturbing family context ends with a re-absorption of the girl in the traditional role as devoted wife, daughter, mother or sister. In the third and last chapter, I concentrate on a study of desire, both male and female, in the stories that have as the matrix the crossdressing adopted by a woman the focus will be a strategy of resistance and rejection of the female identity to embrace masculine performativity. 


\section{Introduction}

A free woman in an unfree society will always be a monster.

[Angela Carter, The Sadeian Woman]

\section{Divine women ${ }^{1}:$ from martyrs to persecuted maidens}

In his introduction to the Novella della figlia del re di Dacia, talking on the popularity of the theme of the persecuted maiden in medieval literature, Aleksandr Vesselovskij distinguishes between the path of suffering and humbleness, destined to prepare to a final reward for the persecuted maiden, and the path of cleverness. The first one is chosen by the woman in legends and the protagonist of an hagiographic story, while the second kind is frequently chosen by the female protagonist of novellas and folktales. ${ }^{2}$ What we know so far is that the first one embodies the succumbed, passive female subject, who is the mirror of a medieval society that produced it, wishing for the submissive Christian woman's condition. This image is the product of the power of men, who in the light of abuses and adversity, want women to show themselves placid and sanctified to the tie of marriage. On the contrary, as the many variants of the story of Griselda from the Decameron testify (Perrault, Pizan, Boccaccio), we are easily induced to associate the second kind of woman to an active role, certainly not to a succumbed one, but rather crafty, astute. Nevertheless, this astuteness is perceived as an escape from the parenthesis of the virtuous behavior in which the first woman is controlled, destined to a superior glory, the divine, ultra mundane

\footnotetext{
${ }^{1}$ In her essay Divine Women, Luce Irigaray opens up a debate on the figure of God, starting from a Feuerbach's statement, and the general assumption of the representation of God as a man. Thus, while exploring the notion of monstrosity by using the figure of Melusine, a serpent-woman, or siren, who leaves and curses her husband forever after that he has broken the oath of never seeing her in her true shape, Irigaray claims that a male God, and thus Western religion, strengthens male power and reducing men to universal subjects and women to body. Thus, she suggests as utopian impetus for change the proposal of a female Divinity made of transcendence, which will help to achieve a self-recognition of a female subjectivity and overcome dualisms. I decided to use the expression 'divine women' as title for the incipit as I wanted to stimulate a reminder to Irigaray's essay, looking at the women of folktales as bodies without subjectivity, narrated by men's culture and thus filtered by it, that may acquire an identity only if their characters were extrapolated from the field of the tradition, throwing that very tradition into a crisis, by assigning them a their owns voice to narrate themselves, as Angela Carter did with her rewritten tales, as Maxine Hong Kingston did in her autobiography by identifying herself with Mu Lan, the Chinese woman warrior. New goddesses for a new humanity. New heroines for a reawake era of the folktale. [see Irigaray, Luce, Divine Women, Local Consumption, Sidney, 1986.]

${ }^{2}$ Vesselovskij- Sade, La fanciulla perseguitata, 1970, Milano, Bompiani, p. 40.
} 
one, where she will be compensated for all the injustices she has suffered during her miserable terrestrial life. The second woman instead, the fox that deceives the devil, refuses the virtue and escapes from that path of virtue toward which she has been guided by the social system. They are both, the saint woman and the terrestrial one, two catalyzing images of the femininity built by a patriarchal logic that seems to gladly accept the passivity of the first one, and blames the ways and customs of the second, her excess of action, her violation of the pre-arranged customs. As testified by Anna Benvenuti, the vulgarization of hagiographies during the late-medieval age has brought to combine the religious knowledge based on a Christian matrix with folk culture, making the sacredness of such biographies escape from the institutional space of Church, and allowing them to circulate in different versions according to different beliefs and local backgrounds. Consequently, also the explanatory and pedagogic intention of hagiographies has left the place to the public opinion of common people and to a multifaceted female subject, now yielded and passive, now active and vigorous. In any case, this new hybrid female is a patchwork derivation of the sacred woman from the previous hagiographies, who is closer to a realistic representation of humankind, totally saturated by the daily popular habits that oral transmissions have produced.

While reading the many essays and works that where necessary for me in order to develop this work, I was surprised by how frequent it is for the folktales to have a hagiographic origin. The majority of women sanctified by the Church as martyrs were always persecuted by men who wanted to pledge them to their sexual will, faith or power. In most cases, these three things overlap. As a matter of fact, two of the principal archetypical tales I have chosen derive from a tradition of martyr women. I am referring, in particular, to the story of Saint Triphine, dated $5^{\text {th }}$ century A.D. and to the story of Saint Olive from Palermo. While the first one has been considered as the original source for the Perraultian La Barbe Bleue (AT312), the second is connected with many late stories, from the most famous Girl without hands by the Grimm Brothers (see Chapter Two), to the more shapeable archetype of the persecuted maiden that served as a founding base for tales like La Gatta Cenerentola/Cendrillon, Beauty and the Beast and Peau d'Ane/Donkeyskin.

The production of devotional books written in vulgar destined to the domestic use is the most meaningful indicator of the progressive diffusion of a religious knowledge that was no more 
exclusively administered within the public and ritual dimension of the Church, but rather on its way toward the private and familiar sphere of affabulation and tale-telling. Participating of the taste for the fable and for the epic novel, the vulgarization of hagiographies became full of useful narrative details which stimulated the imagination and the identification, so the saints became the protagonists of stories in which the pedagogic intention cohabited with the pleasure of reading or listening. The complicated biographical interlacements of the legend of Saint Alexis, the cathartic redemption after killing both his parents from Saint Julian the Hospitaller, the adventures with the dragon of Margaret of Antioch and Saint George, the oneiric geographical horizons of the story of Barlaam and Josaphat animated, with the use of the marvelous genre, the daily way of the living and the imagination of the believers, often becoming an occasion for remarkable conversions (as for instance that of Giovanni Colombini that had changed life after having read the stories of Maria Egiziaca) or for enthusiastic identifications (as in the case of Delphine of Puymichel). ${ }^{3}$

After all, the process of vulgarization of hagiographies is not something that surprises, as Christine de Pizan's La Cité des Dames is a good example of a collection of women's stories belonging both to the Greek-Roman pagan mythology and to Christian religion, presented to us by Christine herself through the three sections of her book.

What is more interesting to find is that most of these stories of patron saints, and I am mainly referring to those having female protagonists, have all a common factor: they are virtuous, incredibly talented and beautiful. They become an object of desire for powerful men, kings, tyrants and commanders. They receive the attention of these men and refuse them. These men respond to their refusal by imprisoning and torturing them. The Christian women, kissed by God, are helped by some saints, in most cases by the Virgin Mary, an angel or some other female martyr saint. These mystical figures intervene during their imprisonment, and they have their wounds healed, their mutilations fixed, their blood reabsorbed. The tyrant repeats the violence definitely, bringing the woman who cannot pledge to his will to the final death. What all these tales of sacred lives have in common is the resistance to male violence and men's frustrated sexual desire, which acquires the male antagonist to repeat violence against the objectified woman. Even though the resistance is paid back with death, and even though we have to figure sexual desire in a blameful Christian ethics, the hagiographies of women show us a first attempt of resistance against the homosocial system by martyrdom, which appears as an extreme strategy of resistance and the condition of subalternity for martyrized women.

\footnotetext{
${ }^{3}$ Benvenuti, Anna, Santi e notai: Ser Baldovino Baldovini e il volgarizzamento della vita di Santa Verdiana da Castelfiorentino, da Studi per Franco Cardini, a cura di Marina Montesano, Firenze, Sismel, Edizioni del Galluzzo, 2010, p. 343. My translation.
} 
However, what I am focusing on in my work is not the religious origin of folktales, even though it is interesting for me to see how the evolution of Christian tales has been vulgarized. Rather, what has moved my research is the world of folktales as a field of action for women, and how their sociability in folktales is paid back, whenever it is and in what ways. My field of interest has been the traditional Italian folktale, taking in consideration authors belonging to different ages, with no exceptions, and finding common elements and variations among the many writings of the same tale. This comparative work, together with a feminist theoretical support, has helped me to look at all of these variations as traces or, in a certain ways, proofs that have supported the final aim of my investigation; that is, to find out how the female subject is located in a subaltern position in the patriarchal universe of the traditional tale. Many folktales belonging to the Western tradition, which has been my main platform of research, present a female figure who is abused, shut down, manipulated by male desire, power and willingness in many different ways that the reader can explore more deeply while reading my essay. At the same time, my intention was not, or at least was not only, to report this subalternity, but rather to make emerge strategies of defense, resistance and deception enacted by women in folktales to accomplish a kind of empowerment, and the limits these strategies present. As a matter of fact, in this feminist revision of the folktale universe some stories will evidence also the limits and risks of this forms of resistance.

But, more specifically, in what ways are these strategies of female resistance developed? While taking into account the tales I analyzed, what I focused on were three strategies: the desire of knowledge, the relationships between women and the crossdressing, or women in male disguise. To provide a valid critical support to my work, I decided to quote authors like Cristina Bacchilega, who was useful to give me an original perspective on the use of Italo Calvino's Italian Folktales as a traditional source in relation to Angela Carter's tales, which can be considered as postmodern fairy tales. In short, the difference between Calvino's collection and Carter's lays in the original purpose of their collections.

The tales by Calvino represent an attempt of arrangement of folktales without the intention of making a selection of them based on thematic reasons, but rather on a regional scale of Italian tradition. He basically tried to do what the Grimm Brothers did with the German fable, or to create an assemblage of popular stories making reference to the respective regional sources, also re-interpreting them through his writing. The collections 
by Angela Carter, on the other hand, both The Bloody Chamber and The First and Second Book of Virago Fairy Tales, can certainly be considered postmodern products. Carter selected in the first case those tales belonging both to the French and German tradition in which the woman-subject is exorcized in her own agency, in her own narrative purpose, in her own desire. In her second collection, she gathers stories of a transversal collection and explores the traditions of various nations and continents, a job which is more similar to Calvino's. Nevertheless, even in this case she took in consideration the female characters and identities. There is in Carter, therefore, the intention to create a tradition of the acting female folktale. ${ }^{4}$

What I have attempted to develop with this essay is an investigation based on a comparative method on the tradition of folktales, mainly founded on the study of the European tradition, particularly the Italian one, and looking at the postmodern writing of the feminist English author Angela Carter. The main aim, through the creation of a dialogue between tradition and contemporary writing (or rewriting), is studying in what ways the woman-subject is limited by the hyperbolic dynamics of violence and patriarchal power inside the folktale, and how she acts in order to defend herself from these dynamics. To such intention, I have tried to focus on the strategies of resistance to male power that can be declined in various ways. Firstly, the most diffused technique in the folktales that I took in examination is the narrative expedient of the woman who helps another woman and who tries to divert gender violence through a net of common support. Then, the other aspect, the most provocative in a certain way, is transvestism as an element of escape. The woman who is protagonist of this type of tale is either obliged or voluntarily chooses her condition of male in disguise to escape from a situation of oppression ('Gift from the journey. Snake husband. At separation she is given magic hairs and a ring or jewel as life index. She wanders disguised as a man. Tested as to whether she is man or woman [H1578.1]. Attempted seduction by queen'). ${ }^{5}$ And, if this gesture sometimes allows her to benefit from the same granted privileges of the masculine world, on the other hand, since being a man in disguise is not considered as the Norm, there is always something that happens in the tale's plot finalized to re-establish the Norm, re-assigning the woman to the femininity that had been stolen from her with her entry in the masculine world.

\footnotetext{
${ }^{4}$ Bacchilega, Cristina, Postmodern Fairy Tales: Gender and narrative Strategies, 1997, Philadelphia, University of Pennsylvania Press, p. 20.

${ }^{5}$ Aarne, Antti, The Types of the Folktale: A Classification and Bibliography. The Finnish Academy of Science and Letters, Helsinki, 1961, p. 144.
} 
What I am interested to show in my search is the analysis of the multiple ways of representation of the relationships within the female universe that I associate to the semantic sphere of what I would try to define as an 'interfered gynosociality'. It is a kind of gynosociality, which has been invaded by the collective imaginary that chauvinist power strengthens, and which reiterates the masculine logics of domain that want the woman to appear hostile for the other woman at any cost. There is always a conjugal exchange as a background for the tales that I have decided to take in exam: a marriage, a satisfaction of the woman with the roles imposed to her by the heteronormative society of which she herself partakes, etc. Folktales represent, from a social point of view, only the common evolution of convictions and shared beliefs. Their spread and passage from an oral to a written tradition is a historical fragment of anthropology, the testimony of the ethical and ethnic values of a community. What makes even more vivid today the images of a story written in, let's say, the 16th century is how much those values belonging to that tale screech with the actual society or, paradoxically, how the gender violence represented in it is still familiar to us.

Yet, even for the epoch in which a story must be located, the situations that occur are hyperbolic: Cinderella's stepsisters amputate their toes and heels to pull their feet inside the crystal shoes and marry the prince, and be able to carry out their role of women and wealthy ladies. The jealous queen, often represented as sterile and of diabolic origins that may justify her cruel attitude, feels her position threatened by the arrival of a new beautiful and virtuous woman (likely passive, see Chapter Two) at the king's palace. The other woman is, in fact, a menace for the queen's place in the nuclear family. Therefore, she makes up strategies to get rid of her rival in love, trying to kill her in the most wicked ways. The final moral always punishes the woman who is acting badly with an atrocious death committed by the king, her husband, who can finally get married with the new woman, who is instead fertile and kind-hearted. A woman for a woman. There is no space for someone who does not respect the ideal of beauty and behaviour demanded by the western tale, for someone who was not able to get pregnant for the king, someone who did not carry out to her wife's duty.

In Le Rire de la Meduse, written by Hélène Cixous in 1976, the French $2^{\text {nd }}$ wave feminist writes these words:

Men have committed the greatest crime against women. Insidiously, violently, they have led them to hate women, to be their own enemies, to mobilize their immense strength against themselves, to be 
the executants of their virile needs. They have made for women an antinarcissism! A narcissism which loves itself only to be loved for what women haven't got! They have constructed the infamous logic of antilove. ${ }^{6}$

Her manifesto has been a revolution throughout the feminist intellectual movement, and this passage is exactly what I attempted to give justice. Conflicts among women are a reiterated element in folktales. Except for investigating the alliance between women as a fundamental union in order to be safe and acquire security, I deepen into the other side of the coin: what happens when women are enemies to other women? And how does this happen? For this reason, the second chapter of my work is dedicated to wicked motherhood and conflictual tensions within gynosociality.

\section{Literary sources}

Why exactly Angela Carter? I decided to use Carter's tales as a mirror on which to reflect the image of the woman belonging to the folktale tradition, since Carter's work, as Cristina Bacchilega has claimed in her Postmodernism and Fairy Tales, is explicitly postmodern. Angela Carter has used her writing as an instrument of redemption for the literary female, by creating fluid, strong, controversial, changeable, picaresque, queer characters. Her collections of stories, The Bloody Chamber, and Angela Carter's Book of Fairy Tales had a very specific aim: to create an anthology of the female folktale, leaving space for female action, for the subjectivity of the narrating Self, and for desire in all its declinations, including that of desire as an awareness of identity. For these reasons, her approach to the fairy tale genre is openly deconstructionist.

One of the objectives of my work on female webs of alliance is the quest for a validation of theoretical concepts already developed by second and third wave feminists. I have taken into account the amount of feminist writers who talked about female desire as an act of re-affirmation of subjectivity and intellectual Self, such as Audre Lorde's essay Eroticism as power, which deals with the necessity of women to re-discover female desire not only as an act of sexual awakening, but rather as a revindication of one's artistic subconscious. Furthermore, I find coherence between my discourse and what expressed Adrienne Rich with her theory of the lesbian continuum, which explores the lesbian existence beyond the notion of sexual identity, making it appear as a way of including

\footnotetext{
${ }^{6}$ Cixous, Helene, The Laugh of the Medusa, Signs, Vol. 1, No. 4. (Summer, 1976), pp. 875-893, p. 878.
} 
woman-identified experiences, as a fil-rouge that connect each single female life. I find it suggestive, then, to imagine a universal connection between these paper women, these characters chained by the canon, and it looks like through their individual story of action, pain, death, impotent opposition is raising a chorus made of talking heroines, who want to be told and who want to narrate their own version of events. Within the prototype of the handless maiden, some versions as the one collected by Afanas'ev and Carter, the catharsis for the female protagonist is possible only because she has decided to tell what happened to her, what kind of abuses she suffered in silence without any opposition, and only by talking she can now have a reward from her own tale, and who has made her suffer cannot do anything but listening to her and waiting in silence for their punishment. The handless woman is now talking. It is because of these single fragments of pride, which interfere with traditional roles and behaviors, that there is a female experience showing the passivity to which these women had been convicted to. It is the story of a miserable collective fate, yes, but it is also the story of how they tried to survive.

I made use, during my research, of the support given by structuralist and poststructuralist theory, and formalist authors. In particular, the Classification by Atti Aarne and Stith Thompson of European folktales has been useful to me in order to compare the many versions of a common narrative archetype, looking for differences throughout the many local tradition. Undoubtedly, before starting my essay I thought immediately about Vladimir Propp and his 1927's essay, Morphology of the Folktale, ${ }^{7}$ where he categorizes thirty-one functions of the characters, and the actants theorized by the Lithuanian semiotician Algirdas Julien Greimas, who tried to reduce the thirty-one categories of Propp to only ten, only considering three basic actants, or ways of action, which are the Actant-Subject (the one who does the action), the Actant-Object of the action (the reason why the Subject does the action) and the Actant-Sender (the receiver of the action). ${ }^{8}$ However, even though I first considered the importance of narratology as a starting point from where I could learn how to structure my work, I realized that my work had to be another one: to find inside categories of action and function, the bugs in the system that could give me the chance to analyze the representation of the female subject in a critical way. If the work of narratology is to look at the narrative structure, the work of feminist criticism is to look

\footnotetext{
${ }^{7}$ Propp, Vladimir, Morfologia della fiaba, a cura di Gian Luigi Bravo, Torino, Einaudi, 2000.

${ }^{8}$ Greimas, Algirdas Julien, Structural Semantics: An Attempt at a Method. trans. Daniele McDowell, Ronald

Schleifer, and Alan Velie. Lincoln, Nebraska: University of Nebraska Press, 1983.
} 
beyond the narrative structure, which means to take into account those categories and see how we can re-interpret tradition.

In addition, it has been thrilling and stimulating to read Marina Warner's brilliant essay From the Beast to the blonde: from Fairy Tales to their tellers, written in 1994, which has given me a first idea of how I wanted to proceed with my own essay: she adopts a diachronic overview of fairy tales, and by doing so she confronts the origin of myths and popular beliefs in the first part of her essay with their direct representation in traditional folktales, which constitute the second part. The work of Italian feminist philosopher Adriana Cavarero Tu che mi guardi, tu che mi racconti. Filosofia della narrazione is probably the reason why I am writing this essay, since her attempt to reconsider the literary tradition and subjectivity from a female and feminist point of view is capable of giving new reading skills on a single literary work. I had never the chance, before, to reflect on the importance of Shehrezade's sister, Dunyazade, who asks her to start telling her a story while she is in front of the murderous sultan. In that very moment, Dunyazade is actually giving Shehrezade the opportunity to start her infinite narration of djinns and people, postponing her death, which will come with the rise of dawn, and saving other women from death. Or, at the same time, I never had the chance to look at the myth of Eurydice as Cavarero shows it, a dead soul who is perfectly at her ease in the Afterlife, who is dragged back to life by Orpheus's desire. Eurydice is gaining back a voice, an agency; even though she is following the command of her husband who wants her alive again, she has now a subjectivity. Does Eurydice really want to come back to life? German poet Rilke's poem about Orpheus and Eurydice reflects on a haunting scene, suspended between the world of the Living and the world of the Dead, where only Orpheus and Hermes take part with attention to what is happening. Eurydice, on the contrary, does not know anything about Orpheus's enterprise, who anticipates her on the way home to the world of Living. She is complete in her dead status, she is already an underworld creature, perfect and indifferent, and she represents the absolute irrelationship. The god Hermes, instead, who is walking at her side, guiding her to human beings, cannot avoid expressing his disappointment when Orpheus turns back. He mourns 'He turned back', and it is exactly when the god says so that Eurydice asks 'Who?' expressing all her alienation from what is going on around her. She did not even notice that Orpheus was trying to bring her to life. Orpheus wanted her alive, not Eurydice herself. Hermes cannot answer to her, because if he answers, he has to explain Orpheus's story to make her understand Orpheus' scope. Eurydice has now 
completely forgotten her human life, now that she is only a soul, she has no past or future, and that is why she cannot have any story. She does not even have a story to tell or to listen. ${ }^{9}$

In her essay, while analyzing different ways of expression of feminist autobiographism and writing as a representation of the self, Cavarero takes the chance to reflect on the impossibility applying the Arendtian notion of unicity. As we can see from the many literary cases represented in her essay, philosophy teaches us that, no matter how much we try, it is impossible to entirely comprehend the 'unicity of human experience', the singularity of any individual. The thread of her entire work is in fact the attempt to deconstruct through concrete proofs the concept of unicity, as Hanna Arendt developed it. From this starting point, I move in order to represent the diversity of any female experience in any representation of it, as different from another even though many stories belong to the same archetypical root, and even though the field of folktales is made of stereotyped role models.

\section{Structural overview}

I have divided my essay in three chapters, dedicating each one of them to a topic and developing a single narrative archetype of those functional to my discourse. In Chapter 1 I focus on the model of Bluebeard (AT312) and the various versions of the tale: St. Gildas' hagiography, 'La Barbe Bleue' from Charles Perrault's Contes de Ma Mére l'Oye, 'The Robber Bridegroom' and 'Fitcher's Bird' by the Grimm Brothers, and 'Mr. Fox' from Angela Carter's Book of Fairy Tales. The chapter explores their differences and meanings, origins, symbols, and the elaboration of the characters enacted throughout the tale. In the second part of the chapter, I will pay special attention to the eponymous tale

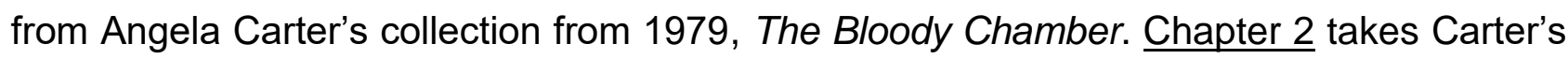
tale 'The Snow Child' as a starting point in order to go deeper inside the mother-daughter relationship and strengthen the prototype of the persecuted maiden, from its antique origin connected with the hagiography of Saint Olive from Palermo to the Peau d'Ane archetype, from the Sleeping Beauty to its Italian versions to the German type of the Girl Without Hands. The second section of the second chapter emphasizes the negative relationships between women, playing with a double bind between the dynamics of male power and gynosociability, exploring some Italian folktales such as 'The young slave' ( $L a$

\footnotetext{
${ }^{9}$ Cavarero, Adriana, Tu che mi guardi, tu che mi racconti. Filosofia della narrazione, Milano, Feltrinelli, 1997
} 
schiavottella) and 'Sun, Moon and Talia' (Sole, Luna e Talia) by Giambattista Basile. Chapter 3 is an analysis of those female characters belonging to the folktale who, whether choosing it or because they have no choice, wear male clothes and mock a masculine identity, and how queer theory can become a parameter to evaluate the limits of desire. In this case, I use as case studies the tales 'The Garlic Patch' and 'The Three Crowns' by Giambattista Basile, 'Costanzo and Costanza' by Giovanni Francesco Straparola and 'Fantaghirò the Beautiful' from Italo Calvino's Italian Folktales. In addition, I have analyzed the notions of disguised masculinity and narration as subalternity using as a support source: Maxine Hong Kingston's 1976 novel, The Woman Warrior: Memoirs of a Girlhood Among Ghosts.

I have used Aarne-Thompson's classification of folktales, which has been incredibly useful in order to look at the common models of fairy tales and give me a confrontation between the different versions. The index, first published by the Finnish anthropologist Atti Aarne and later expanded by the American Stith Thompson in 1910, is a goldmine of unexplored material, where each archetype presents a list of titles of folktales which all belong to that single archetype but at the same time have differences due to cultural adaptations, rewritings, etc. Such differences have been the aspect that has mostly stimulated the curiosity in me to make comparisons and find variances among them.

Speaking about the main collections of Italian folktales I have made reference to, I decided to focus mainly on Giambattista Basile's Pentamerone or The Tale of Tales, first published in 1633, and written in Neapolitan dialect. This literary source represents the second attempt, after Giovanni Francesco Straparola's The Facetious Nights, to recollect in a written shape the oral testimony of folktales. Even though Charles Perrault first, and the Grimm Brothers later will be the most successful folktale writers between the early modern and the contemporary history, we must not forget the relevance of the role played by Italian literary sources like the ones I quoted, which were of fundamental importance for the spread and birth of the folktale as a literary genre. 


\section{Chapter One}

\section{The forbidden room and other dishonored prohibitions: narrations of Bluebeard from Saint Triphine to Angela Carter}

\subsection{The Bluebeard archetype}

As Italo Calvino explains in his essay on the folktale, Sulla fiaba, it is impossible for an historian to find the origin of a single folktale, as a folklorist would tell that the same narrative scheme is present in a quite identical version in a country far away from the country where the observed tale is analyzed, with an absolutely different socio-historical situation. ${ }^{10}$ This is the reason why, before starting to explore the archetype of the Bluebeard tales, I want to precise that my intention is not to find out a genealogy of narration, but rather to look at the variations between the many versions as interesting features from a gender and feminist perspective. Nevertheless, in order to conduct my research to the end considering also the aim of my work, I had to limit my investigation to the Western branch of this narrative model, moving from Italy, to France, to Germany. The elements of the story that caught my attention were mainly three: first of all, the discrepancies in the representations of the female agency and, as a consequence, the way of elaboration of a female subjectivity. Secondly, the notion of desire as expression of sexual initiation for the woman and possession for the man. Finally, how the strategies of resistance are shown in the various editions of the tale and how Angela Carter elaborated these three aspects together in her novella The Bloody Chamber, which I look at as a feminist re-interpretation of the original archetype. As I anticipated, it is difficult and contradictory to attempt to give an historical biography to the existence of a folktale, but what is interesting is how the elements of a common archetype have been changing for centuries. It is probably because of a process of vulgarization that literature has arrived to conceive the story of Bluebeard as we know it from its Perraultian most famous embellishment. As a matter of fact, I included in my analysis some variations of the theme which I encountered in the Grimm Brothers' collection, Calvino's Folktales, Giambattista Basile's Pentamerone and Giuseppe Pitré's Sicilian Folktales. Furthermore, I decided to include in this group also the British tale named Mr. Fox, selected by Angela Carter in her Virago Books of Fairy Tales, which is somewhat a variation of the original Perraultian

10 Calvino, Italo; Lavagetto, Mario, a cura di, Sulla fiaba, 1988, Torino, Einaudi. 
archetype of Bluebeard, but at the same time it is interesting for the contextualization of the female protagonist.

\subsection{A young lady and her husband's keys}

In 'Bluebeard' there is a wealthy man with a weird pigmentation of his beard, who is looking for a wife. There are two sisters, who have to decide who is going to marry him but since the man looks mysterious and creepy stories about his past wives are whispered, they do not take a decision. Finally, the younger of them is seduced by his manners, and starts to think that his beard does not seem that blue, after all, then she accepts. Suddenly, he has to leave her for an important business, so he gives her all the keys of their palace, including the one that opens a little door downstairs, which she will never have to open, otherwise she will prove her husband's fury. She, of course, disobeys and what she discovers is astonishing. The six slaughtered corpses of the previous wives of that man are hanging from the ceiling, rotting in eternity in that bloody chamber. The shock is so strong that the magic key falls from her hands and jumps into a bloodstain, which muds the key permanently, no matter how much she brushes it with water. The blood on the key will be the proof of her treachery. Unexpectedly, the murderous husband comes back that same day, saying that he does not manage to conclude his trade, so he asks back the keys to the young woman, who does not give him back the bloody key. He immediately understands: she knows his secret, she was not faithful to the promise. She entered the bloody chamber, and now she must die like the other women before her. She pities for grace, but he is stuck on his decision, and gives her the time to say her last prayers. Her sister, in the mean time, waits on the balcony of the highest tower of the palace to see whether their warrior brothers are coming to visit the palace of their newly married sister. Just a second before Bluebeard lows the sword on her unfaithful wife's neck to remove her head, her brothers come, and finally kill the ogre husband. The young woman is now free to marry another wealthy and gorgeous man, who will make her forgive the sufferings of her previous union. This is the most famous version of the tale, narrated by Charles Perrault for his king Luis XIV in his Contes de ma mère l'Oye.

This is the reason why it is impossible for me to ignore the story of Saint Triphine, a semi-legendary Breton woman whose story, narrated inside the hagiography of Saint Gildas written during the XI century, presents many elements in common with the story of 
Bluebeard first narrated by Charles Perrault to assume that it represents its first Western version. Of course, from the story of Saint Triphine until the version written by Perrault some centuries have passed. Common sense, in fact, attributes to the character of Barbe Bleue a literary representation of Gilles de Rais, the serial killer nobleman who fought together with Joanne d'Arc, sentenced to death in 1440 for having tortured, raped and killed about 140 children, teenagers and women. However, the story of Saint Triphine already presents what seems to be a serial murderer of women, so that we can probably assume that the attribution to Gilles de Rais has been due to a historical variation made by Perrault or, more likely, a popular association between the representation of Bluebeard and Baron de Rais. The story of Triphine tells us that she is married to Conomor of Brittany, surnamed as 'the Accursed'. In a moment of rage, Conomor beheads Triphine, but Saint Gildas, abbot of Rhuys, comes to put miraculously her head on her neck again. Then Triphine, who is pregnant, runs away in the woods to protect her child. As Marina Warner explains, Cunmar had already killed his previous seven wives before. And Triphine, his latest bride, had received signals from the ghosts of the dead wives, who were trying to warn her of the danger she was encountering while staying there with Cunmar. Apparently, Cunmar used to kill his wives while they were pregnant, and now that Triphine was pregnant too, she was not safe anymore. Warner goes on saying that this desire of Cunmar-Bluebeard of killing his pregnant wives has been attributed to the Oedipal rivalry dramatized in mythology. As King Laius wanted his son Oedipus to be killed because the prophecy of the oracle said that when he grew up he would kill his father, at the same time Cunmar fears the future actions of his heirs. ${ }^{11}$

French iconography underlines this aspect, while representing, as in the case of the seventeenth-century statues of Thriphine and her son both beheaded in Guern, France. At the same time, it is fascinating to think how the representation of Cunmar's dead wives on the medieval frescoes in the church of Saint Nicholas des Eaux, Brittany, evokes the late literary presence of the bloody chamber in the Bluebeard archetype. This means that there has always been a torture chamber, or a secret place where violence and forbidden desires were enacted, and it was connected with the archetype of Bluebeard. It is, in fact, remarkable that already in the Saint Triphine's story that seems to be the first version of this narration, there is an attempt by murdered women to avoid violence to the new bride.

\footnotetext{
11 Warner, Marina, From the Beast to the Blonde. From Fairy Tales to their Tellers, 1994, Vintage, New York, pp- 261-263.
} 
They try to talk with Triphine from the hereafter, and yet they do not manage to save her. On the contrary, Saint Gildas does it and brings the woman back to life.

I think that the best way to make emerge hidden aspects in this motif is by analyzing each single literary version I took in exam, starting from the most known one, which is Charles Perrault's version. What I think first stimulated the idea of a project about female agency in fairy tales was the two morals presented at the ending of the Perraultian model of Bluebeard:

Curiosity's all very well in its way,

But satisfy it and you risk much remorse,

Examples of which can be seen every day.

The feminine sex will deny it, of course,

But the pleasure you wanted, once taken, is lost,

And the knowledge you looked for is not worth the cost. ${ }^{12}$

And then the second one seems to clarify the author's position about the duties of husbands and wives, as

People with sense who use their eyes,

Study the world and know its ways,

Will not take long to realize

That this is a tale of bygone days,

And what it tells is now untrue:

Whether his beard be black or blue,

The modern husband does not ask

His wife to undertake a task

Impossible for her to do,

And even when dissatisfied,

With her he's quiet as a mouse.

It isn't easy to decide

Which is the master in the house. ${ }^{13}$

\footnotetext{
12 Perrault, Charles, Contes de ma mere l'Oye. The Complete Fairy Tales, translated by Christopher Betts, Oxford University Press Inc., New York, 2009, p. 113.

13 lbid., p. 114.
} 
The first moral blames the vice of curiosity, considering it as the danger that every woman risks, since it is part of her nature not to be able to resist to the temptation of satisfying her pleasure. As Maria Tatar argues, Perrault condemns the silliness of the young unexperienced lady, evidencing a blatant blame-the-victim mentality. He also underlines the importance of knowledge for women, even when it is crucial to survival. In other words, yes, it is such a pity for a husband to murder his wives, but of course ladies should know their place and admit that curiosity is dangerous for them. Jack Zipes, on the other hand, in his essay Why Fairy Tales Stick justifies the blaming of Perrault on female curiosity as an allegorical stigmatization of the Precieuses circle, a group of aristocratic women who, in his contemporary age, used their salons as places for intellectual encounters. In other words, the female approach to culture is for Perrault as risky as it would be entering inside a murderer's secret chamber. ${ }^{14}$

There is, undoubtedly, a Biblical echo of the original $\sin$ in the tale, and the curiosity of the young woman seems to be the real blameful aspect of the tale, rather than the presence of a serial murderer who tortured and slaughtered all his wives. The element of prohibition as a temptation for female curiosity is not a priority of the Perraultian French version. Rather, it belongs to all of this model's tradition, and is declined in many ways: in Perrault it is a murder room, while in the Italian tradition as in the German, the room is the gate of Hell and the man is now the devil, now a wizard devoted to the devil. ${ }^{15}$ A 1874 illustration from Walter Crane of the tale of Bluebeard represents Eve standing behind the young woman protagonist, who has the key of the bloody chamber in her hands and who wonders why she should not use it. The picture tries to make implicit the message: the young wife is Eve, and Bluebeard represents God/the male-dominated human kind, who is punishing her for being disobedient. ${ }^{16}$ The forbidden room, thus, becomes the allegory of the Garden of Eden, where Eve wants to go back, and the key is the forbidden tree, always there under Eve's eyes, but untouchable. In each version we take in exam, from Perrault to Carter, the husband deliberately gives her wife the complete bunch of keys, including that one which opens the forbidden room.

\footnotetext{
14 Zipes, Jack, Why Fairy Tales Stick, quoted above, p. 160; see also Patricia Hannon, Fabulous Identities: Women's Fairy Tales in Seventeenth-Century France, Amsterdam, Rodopi, 1994, p. 22.

15 Tatar, Maria, The Annotated Classic Fairy Tales, W. W. Norton \& Company, New York, 2002, p. 146.

16 Fig. 1.
} 
After a month had passed, Bluebeard told his wife that he had to go away for at least six weeks to another part of the country, on an important business matter. He told her to make sure that she enjoyed herself properly while he was away, to invite her friends to stay and to take them out into the country if she wanted to, and not to stint herself wherever she was. 'Here are the keys of the two big store-rooms,' he said, 'the keys for the cupboards with the gold and silver dinner service that is not for every day, and for my strongboxes with my gold and silver coins, and for my jewel-boxes, and here is the master key for all the rooms. As for this small key here, it will unlock the private room at the end of the long gallery in my apartment downstairs. You may open everything and go everywhere, except for this private room, where I forbid you to go; and I forbid it to you so absolutely that, if you did happen to go into it, there is no knowing what I might do, so angry would I be.' She promised to obey his commands exactly; and he kissed her, got into his carriage, and set off on his journey. ${ }^{17}$

One will ask: if Bluebeard did not want his wife to go into the bloody chamber, then why giving her the key? The answer is simple: because he wants to test her, and see what happens while she is tempted by the prohibition. Maria Tatar describes Gustave Doré's 1861 illustration of Bluebeard ${ }^{18}$ saying that

Bluebeard offers his wife the key to the forbidden chamber, admonishing her, with uplifted finger, not to use it. The wife's attraction to the forbidden object is readily apparent, and her eyes are riveted on it, as if by magic. Even Bluebeard's bulging eyes are unable to distract her from the object he puts into her hands. ${ }^{19}$

She is completely enchanted by that magic object, not because it explicitly may look magic, but rather because of the mysteries it unveils. The key, then, is the ultimate proof for the young woman, and since the woman, according to Perrault's moral, is naturally led to fall into the replication of the original sin, she is giving her husband a good reason for taking her life, as the other women before her. He considers her failure to avoid his trap as inevitable. Actually, she accomplishes Bluebeard's malignant plan. While enjoying the company of her hosts who came to give her company while Bluebeard is away, the young woman leaves her guests and flees downstairs, the key in her hand.

\footnotetext{
17 Perrault, Charles, Contes de ma mere l'Oye. The Complete Fairy Tales, quoted above, p. 157. 18 Fig. 2.

19 Tatar, Maria, The Annotated Classic Fairy Tales, W. W. Norton \& Company, New York, 2002, p. 150.
} 
So keen was her curiosity that, without reflecting how rude it was to leave her guests, she went down by a little secret staircase at the back; and she was in such a hurry that two or three times she nearly broke her neck. When the door of the little room was in front of her she stood looking at it for a while, remembering how her husband had forbidden her to open it, and wondering whether something bad might happen to her if she disobeyed, but the temptation was strong and she could not resist it; so she took the little key and, trembling all over, opened the door. At first she could see nothing, because the shutters were closed. After a few moments, she began to see that the floor was all covered in clotted blood, and that it reflected the bodies of several women, dead, and tied up along the wall. They were the wives whom Bluebeard had married, and whose throats he had cut one after the other. She nearly died of fright, and the key, which she had taken out of the lock, fell out of her hand. ${ }^{20}$

To prove the fact that it was a test, we can take into account that Perrault writes that Bluebeard comes back to palace the same night she opens the chamber, as if he already knew that something had happened, and he is ready to take his revenge for his wife's disloyalty. To confirm his doubts, there is the permanent blood on the key. Though she tries to wash it, the blood flows off from the key anyway, and we see the protagonist obsessively scrubbing it to clean it, without any result. Then, hoping he does not notice it, she gives him all the keys, except for the stained one. This will be a way to postpone Bluebeard's punishment, but he already has understood what happened.

The next day, he asked for his keys back, and she gave them to him, but her hand was trembling so much that he easily guessed what had happened. 'Why is it', he asked, 'that the key to my private room is not here with the others?' She replied: 'I must have left it upstairs on my table.' 'Then don't forget to give it to me later,' said Bluebeard. She made excuses several times, but finally she had to bring him the key. Bluebeard examined it, and said to his wife: 'Why is there blood on this key?' 'I know nothing about it,' said the poor woman, as pale as death. 'You know nothing about it?' said Bluebeard; 'but I do: you have tried to get into my private room. Very well, madam, that is where you will go; and there you will take your place, beside the ladies you have seen. ${ }^{21}$

\footnotetext{
${ }^{20}$ Perrault, Charles, Contes de ma mere l'Oye. The Complete Fairy Tales, quoted above, pp.106-107.

21 Ibid., pp. 108-109.
} 
The error of the woman has been discovered, and now she must prepare for the consequences. Then, Bluebeard gives her some minutes to say her last prayers, and she uses this opportunity to ask for help to her sister Anne, who is with her at the palace.

As soon as she was alone, she called to her sister and said: 'Sister Anne' (for that was her name), 'go up to the top of the tower, I beg you, to see if my brothers are coming, for they promised to come today; and if you can see them, make them a signal to hurry.' Her sister Anne went to the top of the tower, and the poor woman below cried up to her at every moment: 'What can you see, sister Anne, sister Anne? Is anyone coming this way?' And her sister would reply: 'All I can see is the dust in the sun, and the green of the grass all round.' Meanwhile, Bluebeard, holding a great cutlass in his hand, shouted as loud as he could to his wife: 'Come down from there at once, or else l'll come and fetch you.' [...] 'What can you see, sister Anne, sister Anne? Is anyone coming this way?' 'I can see,' she replied, 'two horsemen riding towards us, but they are still a long way off . . . God be praised,' she cried a moment later, 'it's our brothers; I shall wave to them as hard as I can, so that they will hurry.'22

Finally, thanks to her brothers who are coming to visit her at the palace, the young woman is free from her murderous husband, who is caught while grabbing his wife's hair to cut off her head, and who is stabbed to death. The young woman and her sister Anne can now recover from the horrible experience, and they can marry two young and honorable fellows.

Bruno Bettelheim, an Austrian-American childhood psychanalyst, wrote in 1976 an essay entitled The Uses of Enchantment: The Meaning and Importance of Fairy Tales, ${ }^{23}$ analyzing the Western tradition of fairy tales from a psychanalytic point of view. Talking about Bluebeard, he argues that the Perraultian version is the first one of this archetype to decline in this way, with such a scenario and characters, the story of the wealthy murderous husband. The previous versions of it, belonging to the Scandinavian and Russian tradition, have animals-husbands as antagonists. Bettelheim goes on saying that Bluebeard cannot even be considered a fairy tale tout court, as there are no magical elements in it, except for the central one, the key:

[...] with the single exception of the indelible blood on the key which gives away the fact that

\footnotetext{
22 Ibid., pp. 111-112.

${ }^{23}$ Bettelheim, Bruno, The Uses of Enchantment: The Meaning and Importance of Fairy Tales, Knopf, New York, 1976.
} 
Bluebeard's bride has entered the forbidden room, there is nothing magical or supernatural in the story. More important, there is no development of any of the characters; although evil is punished in the end, this in itself makes neither for recovery nor for consolation. [...] . The blood on the egg and the key seems to symbolize that the woman had sexual relations. Therefore we can understand her anxious fantasy which depicts corpses of women who had been killed for having been similarly unfaithful. On hearing any of these stories, it immediately becomes obvious that the female is strongly tempted to do what is forbidden to her. It is hard to imagine any more effective way to seduce a person than to tell her: "I am going away; in my absence you may inspect all rooms but one. Here is the key to the forbidden room, which you are not to use." Thus on one level which is easily obscured by the gruesome details of the both Bluebeard and his wife, are exactly the same persons they were before. ${ }^{24}$

Bettelheim, thus, provides his own psychanalytical interpretation to the act of Bluebeard of giving his wife the key of the forbidden room. Opening the door means for the woman to sexually betray her husband, it means to pass the boundary and defy the role imposed to her by her partner. Bettelheim analysis says that

Whether it is Bluebeard or the sorcerer in "Fitcher's Bird," it seems clear that when the male gives the female a key to a room, while at the same time instructing her not to enter, it is a test of her faithfulness to his orders or, in a broader sense, to him. Then these males pretend to depart or do depart for a while, to test their partner's fidelity. Returning unexpectedly, they find that their confidence has been betrayed. The nature of the betrayal may be guessed by the punishment: execution. In certain parts of the world in times past, only one form of deception on the female's part was punishable by death inflicted by her husband: sexual infidelity. ${ }^{25}$

Another interesting aspect is how Bettelheim defines the characters of Bluebeard as static, without an evolution. Furthermore, both the double-bind of sexuality and prohibition and the acknowledgement of female subjectivity and the growing up are all features that will be explored in Angela Carter's tale, The Bloody Chamber.

Finally, in Perrault, we see that the young woman is saved, and the only decision she takes during the whole tale, except for the one of marrying Bluebeard, is to violate the pact with Bluebeard and open the door. Perrault blames the only action she enacts with

\footnotetext{
24 Ibid., p. 199.

25 Ibid., p. 200.
} 
his moral against female curiosity, which implicitly could mean that female agency is blamed too. In her essay, Cheryl Renfroe stresses this tendency to stigmatize curiosity in women, and she is clear about the contribution of Angela Carter to folktales from a feminist perspective:

\begin{abstract}
Western culture has often seen man's disobedience as a virtue. In contesting civil injustice or in resisting tyranny, the rebel's disobedient methods are called revolutionary and courageous; but woman's disobedience, forever colored by traditional interpretations of the first biblical instance of it, is seldom admired. Through the medium of Charter's literary Märchen, Eve's disobedient act, a young wife's flouting of her husband's authority, a woman writer's usurpation of a mysoginous tale, a feminist's reinterpretation of Genesis, all, are vindicated. ${ }^{26}$
\end{abstract}

What about, then, the female character in other Bluebeard's archetypes? How about looking at disobedience as a deliberate act of survival? The Arne-Thompson index classifies Bluebeard and the related forbidden-chamber tales with number 312, but the number 311 refers to 'The heroine who rescues herself and her sisters'. According to Cristina Bacchilega, in contrast with the Perraultian teachings, "bravery, not simply curiosity, lead her to unlock the forbidden chamber, especially when her husband tells her that her sisters are dead, and that she will be too if she disobeys. She must be clever to see him not as the Law but as the enemy. Sometimes she does not trust him in her heart; other times, though proven to be false, he holds her in his power. ${ }^{27}$

I have taken in consideration two versions of this motif, the one from the Grimms, Fitcher's Bird, and its Italian variant, The Silver Nose, collected by Italo Calvino. Although the general plot of these folktales is very similar in each one of them, some symbolic elements change. Plus, I also analyze two other variants of the story, one belonging to the Grimm Brothers as well, and the other one collected by Angela Carter in the Book of Fairy Tales: the first is called The Robber Bridegroom, while the second Mr. Fox. As I said, Bettelheim argues that the Perraultian Bluebeard was unique in its genre, but he also claims that there were some variants in Italian and German culture. One of these is Fitcher's Bird (German, Fitchers Vogel), at the $46^{\text {th }}$ position in Grimms' tales. The story

\footnotetext{
${ }^{26}$ Renfroe, Cheryl, Initiation and Disobedience: Liminal Experience in Angela Carter's "the Bloody Chamber", from Angela Carter and the Fairy Tale, edited by Danielle M. Roemer and Cristina Bacchilega, Wayne State Univerity, Detroit, Michigan, 2001, p. 103.

27 Bacchilega, Cristina, Postmodern Fairy Tales: Gender and narrative Strategies, 1997, Philadelphia, University of Pennsylvania Press, p. 110.
} 
shows an active female character who manages to trick a sorcerer who has imprisoned her and her two sisters. In this tale there is no marital union, but rather the sisters are captured by the sorcerer into a basket and dragged to his house, where they can have access to every room of the palace, except for one basin. Ritually, he catches each one of the sisters, and each one except for the third sister breaks the pact with the sorcerer, who gives them the keys of his house and one egg, in order to verify whether the girls enter into the forbidden room. Any time they enter, they have the egg plopped into the basin for the shock of what they have seen, and so the sorcerer may know that they did not attend the promise. Differently from Bluebeard, the secrets hidden inside the bloody chamber are immediately discovered with the first sister, and this prepares us to expect that one of the sisters will avoid the punishment of the wizard.

[...] he carried her off to his house, where everything was splendid inside, and he gave her whatever she desired. Some time later he said to her: "I have some business to attend to outside the house, and so I must take a trip. Here is an egg. Take good care of it and carry it with you wherever you go. I'm also giving you a key, and if you value your life, don't go into the room that it opens." Nevertheless, when he was gone, she went and opened up this room, and as she entered it, she saw a large basin in the middle with dead and butchered people lying in it. She was so tremendously horrified that the egg she was carrying plopped into the basin. To be sure she quickly took it out and wiped the blood off, but the blood reappeared instantly. She wiped and scraped, but she couldn't get rid of the stain. When the man returned from his journey, he demanded the key and the egg. $\mathrm{He}$ looked at both of them, and he realized right away that she had been in the bloody chamber. "Didn't you pay attention to my instructions?" he said angrily. "Now you'll go back into the bloody chamber against your will." Upon saying this, he grabbed her, led her to the chamber, chopped her into pieces, and tossed her into the basin with the others. ${ }^{28}$

As we can notice, not only does the sorcerer give the sister the key of the forbidden chamber, but also an egg. This may corroborate the theory that the prohibition is a defy that the sorcerer-Bluebeard issues to the victims to prove their loyalty. The same thing occurs to the second sister, who is kidnapped by the sorcerer and dragged into his palace. When the third sister is brought to the palace, she is presented as the smartest of the three.

28 Grimm, Jacob and Wilhelm, The Original Folk and Fairy Tales of the Brothers Grimm, edited by Jack Zipes, p. 145. 
Now the sorcerer wanted to have the third daughter as well. So he captured her and put her into his basket. After he returned home, he gave her the key and the egg before he set out on his journey. However, the third daughter was smart and cunning. She put the egg into a cupboard and then went into the secret chamber. When she found her sisters in the bloody basin, she looked all over the place for their missing parts and put them all together-head, body, arms, and legs. So the two sisters came back to life. Then their sister led them out of the chamber and hid them. ${ }^{29}$

As in the parable of Saint Gildas and Saint Triphine, the sister appears to have miraculous powers at the point that she manages to fix the butchered sisters' bodies and bring them back to life. At the same time, the sorcerer notices that she is the only one who seems to have respected the promise of not entering the bloody chamber, then he believes he can trust her. Therefore, he asks her to become his bride. She accepts, so that she can take advantage of the situation and save her sisters by hiding into the basket.

When the man came home and didn't find any blood stains on the egg, he asked the third sister to become his bride. She said yes, but she told him that before she'd marry him, he had to fill his basket full of gold and carry it to her parents on his back. In the meantime she would make preparations for the wedding. Instead, she stuck her sisters into the basket, covered them with gold, and told them that they were to get help from home. "Now carry this basket to my parents," she said to the man, "but don't dare to stop and rest along the way. I can see everything from my window." So the man lifted the basket onto his back and went on his way. It was, however, so heavy that he was almost crushed to death by the weight. At one point he wanted to rest, but one of the sisters immediately cried out from the basket: "I see from my window that you're resting! Get a move on at once!"

Here I anticipate an element of my essay that is the action of disguise as strategy of resistance, in a very different way from what it means to be in male disguise (see Chapter Three). The smart sister covers her body with feathers so that she will be unrecognizable, and tells the bridegroom-sorcerer to come up to her house so that they can celebrate their marriage. But it appears to be a way to make him go inside her house, and then burn the sorcerer and his friends to be free from his murderous habits:

Back at his place, the bride took a skull, decorated it with jewels and set it on the window case. Then she invited the sorcerer's friends to the wedding, and after that was done, she dipped herself into a barrel of honey, cut open a bed, and rolled around in the feathers so that it was impossible to recognize

${ }^{29}$ lbid., p. 146. 
her because she looked so strange. And this is how she set out on her way. [...] Soon thereafter she met the bridegroom, who was on his return home: "Where are you coming from, oh, Fitcher's bird?" "From Fitze Fitcher's house, haven't you heard?" [...] The bridegroom looked and saw the decorated skull. He thought it was his bride and waved to her. However, once he and his guests were all gathered inside the house, the helpers who were sent by the sisters finally arrived. These people locked all the doors of the house and then they set fire to it. And since nobody could get out, they were all burned to death. ${ }^{30}$

As Italo Calvino refers, the Italian answer to Bluebeard can be found in the region of Piedmont under the title of The Devil with the Silver Nose, or simply Silver Nose. The story is very similar to Fitcher's Bird, and Calvino connects its origins to the medieval theological legends. He declares that his version is made by an integration of the lacking Piedmontese tale with a Bolognese tale (La fola del diavel, by Carolina Coronedi-Alberti, Al sgugiol di ragazù, Bologna, 1883) and a Venetian one (El Diavolo, by Domenico Giuseppe Bernoni, Fiabe popolari veneziane, Venezia, 1893). In Silver Nose, the sorcerer from Fitcher's Bird and the killer husband from Bluebeard are substituted from none other than the Devil himself, who needs innocent souls and wants to challenge three sisters by bringing them as servants to his palace. As in the other tales, here there is a proof to pass too. There is no egg, nor magical keys. The story begins with a washerwoman's daughter who is unsatisfied with her life and cries 'I intend, to leave home, even if I have to go and work for the Devil.' Then, not many days afterward, they receive a visit from a gentleman attired in black. He is the height of courtesy and has a silver nose, and tells the mother: 'I am aware that you have three daughters, would you let one come and work for me?' The mother would have consented at once, had it not been for that silver nose which she didn't like the looks of. She called her oldest girl aside and said, 'No man on earth has a silver nose. If you go off with him you might well live to regret it, so watch out.' The girl ignores her mother's advice and goes with the Silver Nose man. The same story as in Fitcher's Bird and Bluebeard happens: the girl is shown the palace, she is said she can have access to any room inside it, but however she is given the key. Marina Warner's interpretation of the devil-bridegroom's physical appearance identifies several omens of the secret personality they hide. In Calvino's version, the antagonist has no beard, but rather a silver nose. 'He is presented in his customary aristocratic attire, a boss who demands sexual services along with good housekeeping, and his metal appendage could mask a nose wasted from syphilis. ${ }^{31}$ At the same time, the beard is also a double

\footnotetext{
30 Ibid., p. 147.

${ }^{31}$ Warner, Marina, From the Beast to the Blonde. From Fairy Tales to their Tellers, quoted above, p. 256.
} 
reference to hyperbolic sexual desires, diabolical customs and a powerful virility (see section 1.5).

When they reached the door of the last room, Silver Nose gave her the key and said, "You must never open this door for any reason whatever, or you'll wish you hadn't! You're in charge of all the rooms but this one." He's hiding something from me, thought the girl, and resolved to open that door the minute Silver Nose left the house. That night, while she was sleeping in her little room, in tiptoed Silver Nose and placed a rose in her hair. Then he left just as quietly as he had entered. ${ }^{32}$

As we can notice from this passage, there is a new symbol that proves the guiltiness of the girl, different from the bloodstained key or the egg, a rose, and as we can see further, the devil uses a different flower for any sister. A rose, a carnation, a jasmine.

Finding herself alone with all the keys, the girl ran and unlocked the forbidden door. No sooner had she cracked it than smoke and flames shot out, while she caught sight of a crowd of damned souls in agony inside the fiery room. She then realized that Silver Nose was the Devil and that the room was Hell. She screamed, slammed the door, and took to her heels. But a tongue of fire had scorched the rose she wore in her hair. Silver Nose came home and saw the singed rose. "So that's how you obey me!" he said. He snatched her up, opened the door to Hell, and flung her into the flames. ${ }^{33}$

Later, both the second and the third sister are called to serve at Silver Nose's palace, and both of them open the bloody chamber. But while the second one does not notice the carnation in her hair and falls in Hell, the third one, Lucia, is as smart as the third sister in Fitcher's Bird.

She too was shown around the house and given the same instructions as her sisters. She too had a flower put in her hair while she was sleeping: a jasmine blossom. The first thing Lucia did when she got up next morning was arrange her hair. Looking in the mirror, she noticed the jasmine. "Well, well!" she said. Silver Nose pinned a jasmine on me. How thoughtful of him! Who knows why he did it? In any case I'll keep it fresh." She put it into a glass of water, combed her hair, then said, "Now let's take a look at the mysterious door." She just barely opened it, and out rushed a flame. She glimpsed countless people burning, and there in the middle of the crowd were her big sisters. "Lucia! Lucia!" they screamed. "Get us out of here! Save us!" At once Lucia shut the door tightly and began

\footnotetext{
${ }^{32}$ Calvino, Italo, Italian Folktales, Penguin Books, edited by Jack Zipes, p. 27.
}

33 Ibid. 
thinking how she might rescue her sisters. By the time the Devil got home, Lucia had put her jasmine back in her hair, and acted as though nothing had happened that day. Silver Nose looked at the jasmine. "Oh, it's still fresh," he said. ${ }^{34}$

As for Fitcher's Bird, Silver Nose belongs to the motif number 311, 'the heroine rescues her sisters'; and as in Fitcher's Bird, Lucia mocks the devil with the basket's trick. She prepares a rag doll the same size as herself to put in the bed under the sheets, she cuts off her own braids and sew them on the doll's head. Then, she hides in the devil's bag with her two sisters and he brings them back home. 'So the family was finally reunited. Since Lucia had also carried off great sums of the Devil's money, they were now able to live in comfort and happiness. They planted a cross before the door, and from then on, the Devil kept his distance. 35

The Robber Bridegroom and Mr. Fox, as I anticipated, are very similar in their shape. The Robber Bridegroom (in German, Der Räuberbräutigram) is the $40^{\text {th }}$ tale from the Grimm Brothers' collection, and it corresponds to the Aarne-Thompson type 955, 'the robber bridegroom'. I included it in my research because I found coherence with the dynamics of female alliance against violence, which does not appear in Mr. Fox. There are various versions of the tale, according to the Grimms' edition. In some of them, the bridegroom is a prince and the girl a princess, while in some others he is a robber and the girl is a baker's daughter. However, I will try to take into account both of them. In the story, the girl protagonist, a baker's daughter, is invited by her fiancé to visit him at his house into the woods. She refuses to go, at first, because she does not trust him and she does not love him as her fiancé. But he insists: 'If that was her concern, the prince told her, he would readily help her by tying a ribbon on each tree so that she could easily find her way. Nevertheless, she tried to postpone the trip for some time since she inwardly dreaded it. Finally, she couldn't make any more excuses and had to set out one day on the journey. ${ }^{36}$ While in the version of the baker's daughter she throws peas and lentils on her way in order to not lose the path, in the princess version she ties a ribbon to each tree for the same reason. When she arrives, she encounters an old woman attending her: 'When she finally arrived at a large house, everything was quiet inside, and only an old woman sat in front of the door. "Can you tell me whether the prince, my bridegroom, lives here?" "It's good, my child, that you have come now," responded the woman, "because the prince is

\footnotetext{
34 Ibid., pp.27-28.

35 Ibid., p. 30.

${ }^{36}$ Grimm, Jacob and Wilhelm, The Original Folk and Fairy Tales of the Brothers Grimm, quoted above, p. 135.
} 
not at home. Before your arrival, I had to fetch water and pour it into a large kettle. They want to kill you, and afterward they'll cook and eat you."' The old woman, then, alerts her of the danger she is going to encounter, then she tells the young woman to hide, so that the villainous band of robbers will not see her, and from her shelter she sees the violence enacted in the robber's house.

The robbers grabbed hold of the old grandmother, killed her, and pulled off all the rings from her fingers, one after the other. However, the gold ring on one of her fingers wouldn't come off. So one of the robbers took a hatchet and chopped off the finger, but the finger sprang behind the barrel and fell right into the princess's lap. After the robbers had searched in vain for the finger a long time, one of them spoke out: "Has anyone looked behind the large barrel?" "It's better if we continue searching when there's more light," another said. "Early tomorrow morning we'll continue looking. Then we'll soon find the ring." Soon thereafter the robbers lay down to sleep in the cellar, and as they were sleeping and snoring, the bride came out from behind the barrel. The robbers were lying there all in a row, and she had to step over the sleeping men until she came to the door. She cautiously entered the rooms in between, and she was constantly afraid that she might wake someone, but fortunately nothing happened, and once she reached the outside door and was in the forest again, she followed the ribbons, for the moon shone brightly up to the time that she managed to reach her home. ${ }^{37}$

Some aspects are curious, like the fact that in this version it is the grandmother of the maiden who gets killed, while in the baker's daughter version is a young and wealthy lady to die and be chopped into pieces, her flesh salted and prepared to be eaten by the cannibal robbers.

In Angela Carter's Mr. Fox, ${ }^{38}$ the story begins very similarly to the one presented by the Grimms. The young lady is given the name of Lady Mary, while Mr. Fox is described as the bravest and most gallant among her lovers. His origins, as well, are unknown: 'No one knew who Mr. Fox was; but he was certainly brave, and surely rich, and of all her

\footnotetext{
${ }^{37}$ Ivi, p. 136.

38 'The initiatory pattern and other commonalities of these three tale types become even more evident if we consider folk versions that are closer to the oral tradition than the Perrault or Grimms' texts are. How the girl comes under Bluebeard's power varies. She marries him of her own free will; she is offered by her father; she is traded; she is tricked or captured. Reasons for choosing to marry him include money or, in some cases, her attraction to a special feature-sometimes even his beard.10 While not perhaps significant in themselves, the many reasons given for the marriage multiply interpretive possibilities: Perrault to the contrary, then, the girl is not always the guilty party. As for the Bluebeard figure, he is inevitably presented as Other, belonging to a different class, land, or world altogether. He may be an ogre, a vampire-like creature, a cannibal, or even the Devil himself. Certainly a stranger, he is also a mysterious being who usually presents himself as a rich man with a beard, be it blue or green, or a silver nose in an Italian version, as the visible clue to his otherness.' Bacchilega, Cristina, Postmodern Fairy Tales: Gender and narrative Strategies, 1997, Philadelphia, University of Pennsylvania Press, pp.109-110.
} 
lovers, Lady Mary cared for him alone.' Here, the typical prohibition of this narrative archetype is not explicitly presented, but rather implicit. Even though Lady Mary agrees to marry him, Mr Fox does not invite her to his castle, then she decides to go on her own.

Lady Mary asked Mr Fox where they should live, and he described to her his castle, and where it was; but, strange to say, he did not ask her, or her brothers, to come and see it. So one day, near the wedding-day, when her brothers were out, and Mr Fox was away for a day or two on business, as he said, Lady Mary set out for Mr Fox's castle. And after many searchings, she came at last to it, and a fine strong house it was, with high walls and a deep moat. ${ }^{39}$

Suddenly, when she arrives at Mr Fox's castle, she 'went on, till she came into the hall, and went up the broad stairs till she came to a door in the gallery, over which was written: Be bold, be bold, but not too bold,/ Lest that your heart's blood should run cold.' She has arrived in front of the infamous bloody chamber of the previous tales, and

she opened the door, and what do you think she saw? Why, bodies and skeletons of beautiful young ladies all stained with blood. So Lady Mary thought it was high time to get out of that horrid place, and she closed the door, went through the gallery, and was just going down the stairs, and out of the hall, when who should see through the window, but Mr Fox dragging a beautiful young lady along from the gateway to the door. Lady Mary rushed downstairs, and hid herself behid a cask, just in time, as Mr Fox came in with the poor young lady who seemed to have fainted. Just as he got near Lady Mary, Mr Fox saw a diamond ring glittering on the finger of the young lady he was dragging, and he tried to pull it off. But it was tightly fixed, and would not come off, so Mr Fox cursed and swore, and drew his sword, raised it, and brought it down upon the hand of the poor lady. The sword cut off the hand, which jumped up into the air, and fell of all places in the world into Lady Mary's lap. Mr Fox looked about a bit, but did not think of looking behind the cask, so at last he went on dragging the young lady up the stairs into the Bloody Chamber. ${ }^{40}$

What is interesting in these tales is the female agency that makes the ending achievable. In both cases, the ladies talk with the murderers, telling them they had a dream, where they dreamt of going to the palace of their betrothed to visit him, and instead they assisted to this horrible fact. This gradual dream-confession is always ended up with the maiden showing the cut finger or hand, confirming that they really saw what they are telling and that it was not a dream. According to what we read in Angela Carter's notes on Mr. Fox,

${ }^{39}$ Carter, Angela, The First and Second Book of Virago Fairy Tales, 2 vol., 1991; 1993, Virago Press, London, p. 44.

40 lbid., p. 45. 
her adaptation is based on an Arkansas version of the story told to Vance Randolph in the Ozark mountains, in the early 1940s. ${ }^{41}$ The fairy tale, she says, is changing, almost imperceptibly, into the telltale, the outrageous lie imparted with an utterly straight face for the pure pleasure of it. Even though generally, in popular culture, the fox is always an animal associated with greed and cunning, here the fox's incarnation as a psychopathic murderer gives an added frisson to veterans of British childhoods who recall the 'foxy gentleman' who wanted to eat Jemima Puddleduck. ${ }^{42}$ As we can see, there is always a connection between perverse sexual desires and the representation of the murderous husband of the Aarne-Thompson 312 type. Furthermore, if we pay attention to the third sister, she is always the one who manages to save the situation and her sisters by transgressing the ritual of the egg or the flower among her hair. The girl's distinctive treatment of the egg, ball or flower in AT311 versions is significant. Her sisters submit to the Bluebeard figure's orders as much as they possibly can by carrying the test gift with them, even when they are going into the bloody chamber. Thus, these women are symbolically submitting their life to his death project. The girl who leaves her egg or flower outside the bloody chamber recognizes the primacy of self-preservation.

\section{3. "I only did what he knew I would": Angela Carter's The Bloody Chamber}

The wind blew high, my heart did ache/ to see the hole the fox did make.

The Bloody Chamber was Angela Carter's literary debut. Gollancz published it in 1979, and as Carter said in a 1985 interview, 'My intention was not to do 'versions' or, as the American edition of the book said, horribly, 'adult' fairy tales, but to extract the latent content from the traditional stories. ${ }^{43}$ In other words, Carter attempted to look beyond the first level of interpretation of folktales, looking for an extrapolation of the desire in them and how that desire had been repressed from the masculine representation of female subjectivity. In relation to the Bluebeard's tradition, The Bloody Chamber is not only a rewriting of it, but rather it represents an act of rebellion by Carter against the classical fairy tale archetypes. There is a replication of the French, aristocratic setting; we notice that from the description of the backgrounds and the French reference to the characters: Jean-Yves, the Marquis, the Marquis' ancestor who had lived after the years of the French

\footnotetext{
${ }^{41}$ Carter, Angela, The First and Second Book of Virago Fairy Tales, quoted above, p. 576.

42 Jacobs, Joseph, English Fairy Tales, London, 1895.

${ }^{43}$ Haffenden, John Angela Carter in Novelists in Interview, New York, Methuen Press, 1985, p. 80.
} 
Terror and had committed a choker of rubies to re-vindicate her noble survival to the guillotine during the French Revolution; supposedly, thus, the story could be set about a hundred years later the French Revolution, or, at the beginning of the twentieth century. The story, narrated in first person, opens with the new bride sleeping in the wagon-lit of a train, while she is moving to the castle of the Marquis she has married, and from a retrospective, she tells us about her and the encounter with her husband. The narrator is a seventeen-year-old woman when the events told happen, who studied as a pianist, whose mother was a heroic example of rebellion. Actually, she went as explorer in China living incredible adventures, killing a tiger and fighting Chinese pirates. 'My eagle-featured, indomitable mother; what other student at the Conservatoire could boast that her mother had outfaced a junkful of Chinese pirates, nursed a village through a visitation of the plague, shot a man-eating tiger with her own hand and all before she was as old as I?'44 We already know she started having confidence with the Marquis while discussing about music, and that he seduced her while inviting her at the Tristan und Isolde by Richard Wagner. What is interesting is the fact that, as for the tales of Bluebeard tradition, also the stories about the Marquis' past are torrid and full of mysterious details. She tells us that he had married before, at least three times, and that the two wives had died in unclear circumstances. What is more, the bodies of both of them were not found.

[...] my Marquis had been married before, more than once, and I remained a little bemused that, after those others, he should now have chosen me. Indeed, was he not still in mourning for his last wife? [...] A Romanian countess, a lady of high fashion. Dead just three short months before I met him, a boating accident, at his home, in Brittany. They never found her body but I rummaged through the back copies of the society magazines my old nanny kept in a trunk under her bed and tracked down her photograph. The sharp muzzle of a pretty, witty, naughty monkey; such potent and bizarre charm, of a dark, bright, wild yet worldly thing whose natural habitat must have been some luxurious interior decorator's jungle filled with potted palms and tame, squawking parakeets. Before that? Her face is common property; everyone painted her but the Redon engraving I liked best, The Evening Star Walking on the Rim of Night. To see her skeletal, enigmatic grace, you would never think she had been a barmaid in a café in Montmartre until Puvis de Chavannes saw her and had her expose her flat breasts and elongated thighs to his brush. And yet it was the absinthe doomed her, or so they said. The first of all his ladies? That sumptuous diva; I had heard her sing Isolde, precociously musical child that I was, taken to the opera for a birthday treat. My first opera; I had heard her sing Isolde. With what white-hot passion had she burned from the stage! So that you could tell she would die young. We sat high up, halfway to heaven in the gods, yet she half-blinded me. And my father,

\footnotetext{
${ }^{44}$ Carter, Angela, The Bloody Chamber and other stories, from Burning your boats, Penguin Books, London,
} 1995, p. 111. 
still alive (oh, so long ago), took hold of my sticky little hand, to comfort me, in the last act, yet all I heard was the glory of her voice..$^{45}$

She defines them as three muses, three graces, in comparison to her, who at that time looked like a 'poor widow's child with my mouse-coloured hair that still bore the kinks of the plaits from which it had so recently been freed, [her] bony hips, [her] nervous, pianist's fingers. ${ }^{46}$ This difference, in fact, between her and the Marquis' previous wives makes us assume that the Marquis is attracted by the idealization of her purity and chastity. When they go at the opera, he wants her to wear a thin white muslin shift, tied under the breast. The whiteness of her clothes, together with the tightness above her chest, suggests an erotization of innocence itself. The whole novella can be read as a long omen of death, a premonition of the tragedy that is going to explode during the last part of the book, and probably the omniscient narration of the protagonist, who is narrating a past event, is attempting as well to rationalize everything that happened to her with the Marquis from the singular moments of his courtship to the opening of the bloody chamber. There are a plenty of elements that evoke a funereal ending, one of these is the already mentioned choker of rubies, the Marquis' wedding gift for her, as an inauguration of the pleasure their marriage is hiding.

His wedding gift, clasped round my throat. A choker of rubies, two inches wide, like an extraordinarily precious slit throat. After the Terror, in the early days of the Directory, the aristos who'd escaped the guillotine had an ironic fad of tying a red ribbon round their necks at just the point where the blade would have sliced it through, a red ribbon like the memory of a wound. And his grandmother, taken with the notion, had her ribbon made up in rubies; such a gesture of luxurious defiance! That night at the opera comes back to me even now... the white dress; the frail child within it; and the flashing crimson jewels round her throat, bright as arterial blood. ${ }^{47}$

Of course, for the Marquis, that choker of rubies has lost its previous meaning, it does not have to represent anymore the pride of the aristocrat woman who survived the massacre and used to wear it, but rather it becomes for him the anticipation of the punishment for the disobeying wife. He obliges her to never take off her choker, and the reader gradually can notice how the Marquis has always prepared his wife to temptation. In Carter's version,

\footnotetext{
45 Ivi, p. 113

${ }^{46}$ Ivi, 114.

47 lbid.
} 
more than anywhere else, the allegory of Eve and her get-out from the Garden of Eden is enacted. After she discovers the bloody chamber and talks to Jean-Yves saying to him 'I only did what he knew I would,' she is expressing the synthesis of all the heroines of the Bluebeard's archetype: the recognition of the devil/husband's exposure to temptation to prove to what extent the maiden would go. There is a scene, while they are lying in bed and he is going to have sex with her for the first time, in which the Marquis kisses the rubies' choker.

He made me put on my choker, the family heirloom of one woman who had escaped the blade. With trembling fingers, I fastened the thing about my neck. It was cold as ice and chilled me. He twined my hair into a rope and lifted it off my shoulders so that he could the better kiss the downy furrows below my ears; that made me shudder. And he kissed those blazing rubies, too. He kissed them before he kissed my mouth. Rapt, he intoned:' Of her apparel she retains/Only her sonorous jewellery. ${ }^{48}$

With this gesture, that preceeds the act of defloration, the Marquis evokes the sadism of the Sultan Shahryiar from the Arabian Nights, who takes a bride each night and then, after having raped her, sentences her to death. By kissing the choker of red rubies, which reminds of a slit throat, he is enjoying, tasting, perhaps eroticizing, the death of his new wife. 'When I saw him look at me with lust,' she says, while she is thinking about her appearance in the mirror while putting the choker on, 'I dropped my eyes but, [...] I saw myself, suddenly, as he saw me, my pale face, the way the muscles in my neck stuck out like thin wire. I saw how much that cruel necklace became me. And, for the first time in my innocent and confined life, I sensed in myself a potentiality for corruption that took my breath away. ${ }^{49}$ What the Marquis is eroticizing, as the Marquis de Sade in Justine, is the potentiality for corruption of the protagonist, her natural disposition, as a woman, for curiosity, disobedience and transgression. The other two wedding presents he gives her as she arrives at the Marquis' castle are a piano and a portrait of Saint Cecilia while playing the piano. As explained by Kathleen E.B. Manley in The Woman in Process, there is a parallelism between Cecilia's martyrdom and the potential of martyrdom in the bride. 'Ultimately, Saint Cecilia was martyred because of her dedication to being a celibate Christian, and later the protagonist wonders about the nature of the saint's martyrdom,

\footnotetext{
48 lbid., p. 118.

${ }^{49}$ Ivi, p. 115.
} 
which, like the Marquis's plan for his bride, was decapitation», and as the narrator herself says while she is looking at Cecilia's picture "I saw myself as I could have wished to be,' which means that the protagonist's wish to be like her shows her seriousness about her music. ${ }^{50}$

The scene of the first night together probably represents the gist of Carter's theorization about the Sadeian woman and the objectifying male gaze sexualizing the female body, and she describes the moment of sex between the narrator and the Marquis as a sort of mystical initiation rite to womanhood according to male fantasy. Surrounded by mirrors, the bed is covered with lilies, which suggest a funereal rite (another omen of the destiny prepared for the new bride). White flowers are covering the nuptial bed as if it were a graveyard. The narrator, still wearing the choker of rubies, sees herself reflected on the multitude of mirrors and loses the perception of her own identity, becoming then a 'multitude of girls'.

Our bed. And surrounded by so many mirrors! Mirrors on all the walls, in stately frames of contorted gold, that reflected more white lilies than I'd ever seen in my life before. He'd filled the room with them, to greet the bride, the young bride. The young bride, who had become that multitude of girls I saw in the mirrors, identical in their chic navy blue tailor-mades, for travelling, madame, or walking. [...] Our bed. And surrounded by so many mirrors! Mirrors on all the walls, in stately frames of contorted gold, that reflected more white lilies than I'd ever seen in my life before. He'd filled the room with them, to greet the bride, the young bride. The young bride, who had become that multitude of girls I saw in the mirrors, identical in their chic navy blue tailor-mades, for travelling, madame, or walking. [...] And he kissed those blazing rubies, too. He kissed them before he kissed my mouth. Rapt, he intoned:' Of her apparel she retains/Only her sonorous jewellery.' A dozen husbands impaled a dozen brides while the mewing gulls swung on invisible trapezes in the empty air outside. ${ }^{51}$

As we see, the act of penetration itself is described as the act of a husband impaling a dozen brides, another warning of the Marquis' potential brutality and the butchering of brides he enacted. The link between the mirror and the objectification of female pleasure is represented again in another novel by Angela Carter, The Passion of New Eve. Here, the protagonist and narrator, Evelyn, is having an affair with a young woman, Leiah, and

\footnotetext{
50 Manley, Kathleen E. B. , The Woman in Process in Angela Carter's "The Bloody Chamber", from Danielle M. Roemer and Cristina Bacchiega, Angela Carter and the Fairy Tale, Wayne State University Press, 1998, p. 83.

${ }^{51}$ Carter, Angela, The Bloody Chamber and other stories, quoted above, pp. 120-121.
} 
during chapter one, he describes their sexual rituals, when Leilah contemplates her beauty for her own in the mirror while Evelyn is watching her and interfering with her pleasure of self-contemplation, sexualizing it through the male gaze. Soon after, he describes the act of sex between them, comparing Leilah to a she-devil who wants to corrupt his soul:

[...] she danced her naked dance for me and for her reflection in her cracked mirror. She was black as my shadow and I made her lie on her back and parted her legs like a doctor in order to examine more closely the exquisite negative of her sex. Sometimes, when I was exhausted and she was not, still riven by her carnal curiosity, she would clamber on top of me in the middle of the night, the darkness in the room made flesh, and thrust my limp cock inside herself, twittering away as she did so like a distracted canary, while I came to life in my sleep. Waking just before she tore the orgasm from me, I would, in my astonishment, remember the myth of the succubus, the devils in female form who come by night to seduce the saints. Then, to punish her for scaring me so, I would tie her to the iron bed with my belt. I always left her feet free, so she could kick away the rats. ${ }^{52}$

The mirror, in Carter, may be read as well as the previous phase of the evolution of language in human beings, according to Lacan's thought, the so-called mirror phase, or phase of the mother, that anticipates the verbal language, which is the phase of the father. We can assume that in Carter's novella, the narrator-protagonist, who describes her feeling of alienation looking at herself in the multitude of mirrors, is representing the detachment from sexual desire for women in a heteronormative sexual intercourse. Actually, as Manley says, 'Carter's mirrors in "The Bloody Chamber", then, indicate not only the protagonist's dependence on her sense of innocence but also her lack of a sense of herself as subject. 53

After the sex scene, follows the moment of the Marquis' departure for business in New York, when he, as in the other versions, leaves her the keys of the castle. He makes her promise she will not ever take off the rubies' choker and that she will never enter inside the bloody chamber, where, as he explains to her, he goes when he needs to fancy that he is not married.

All is yours, everywhere is open to you except the lock that this single key fits. Yet all it is is the key to a little room at the foot of the west tower, behind the still-room, at the end of a dark little corridor

\footnotetext{
${ }^{52}$ Carter, Angela, The Passion of New Eve, Virago Press, London, 1982, p. 23.

${ }^{53}$ Manley, Kathleen E. B., The Woman in Process in Angela Carter's "The Bloody Chamber", quoted above, p. 86.
} 
full of horrid cobwebs that would get into your hair and frighten you if you ventured there. Oh, and you'd find it such a dull little room! But you must promise me, if you love me, to leave it well alone. It is only a private study, a hideaway, a "den", as the English say, where I can go, sometimes, on those infrequent yet inevitable occasions when the yoke of marriage seems to weigh too heavily on my shoulders. There I can go, you understand, to savour the rare pleasure of imagining myself wifeless. ${ }^{54}$

Here, as in the classical folktales of this motif, the wife disobeys and goes to the bloody chamber. She spends hours of leisure after he leaves, roaming around the castle, having a bath, playing music at the piano, and after she talks at the telephone with her mother and she recognizes her unhappiness, the bunch of keys he has left her falls on the rug, and only then she realizes how she can spend her next hours, and she thinks about the opening of the bloody chamber as something that could give her the chance to better understand now her mysterious husband.

When everything was lit as brightly as the café in the Gare du Nord, the significance of the possessions implied by that bunch of keys no longer intimidated me, for I was determined, now, to search through them all for evidence of my husband's true nature. His office first, evidently I took the forbidden key from the heap and left the others lying there. It was now very late and the castle was adrift, as far as it could go from the land, in the middle of the silent ocean where, at my orders, it floated, like a garland of light. And all silent, all still, but for the murmuring of the waves. I felt no fear, no intimation of dread. Now I walked as firmly as I had done in my mother's house. [...] The key slid into the new lock as easily as a hot knife into butter. No fear; but a hesitation, a holding of the spiritual breath. 'There is a striking resemblance between the act of love and the ministrations of a torturer,' opined my husband's favourite poet; I had learned something of the nature of that similarity on my marriage bed. And--just one glimpse of it before my little flame caved in and I was left in absolute darkness--a metal figure, hinged at the side, which I knew to be spiked on the inside and to have the name: the Iron Maiden. ${ }^{55}$

Gradually, one by one, the protagonist encounters the Marquis' previous wives' dead bodies.

[...] Each time I struck a match to light those candles round her bed, it seemed a garment of that innocence of mine for which he had lusted fell away from me. The opera singer lay, quite naked,

\footnotetext{
${ }^{54}$ Carter, Angela, The Bloody Chamber and other stories, quoted above, p. 124.

55 Ibid., p. 131.
} 
under a thin sheet of very rare and precious linen, such as the princes of Italy used to shroud those whom they had poisoned. I touched her, very gently, on the white breast; she was cool, he had embalmed her. On her throat I could see the blue imprint of his strangler's fingers. The cool, sad flame of the candles flickered on her white, closed eyelids. The worst thing was, the dead lips smiled. Beyond the catafalque, in the middle of the shadows, a white, nacreous glimmer [...] made out a skull; yes, a skull, so utterly denuded, now, of flesh, that it scarcely seemed possible the stark bone had once been richly upholstered with life. [...] I recognized her the moment I saw her; face of the evening star walking on the rim of night. [...] And where was she, the latest dead, the Romanian countess who might have thought her blood would survive his depredations? [...] Then, for some reason--perhaps some change of atmosphere wrought by my presence--the metal shell of the Iron Maiden emitted a ghostly twang; With trembling fingers, I prised open the front of the upright coffin, with its sculpted face caught in a rictus of pain. Then, overcome, I dropped the key I still held in my other hand. It dropped into the forming pool of her blood. She was pierced, not by one but by a hundred spikes, this child of the land of the vampires who seemed so newly dead, so full of blood ... oh God! how recently had he become a widower? How long had he kept her in this obscene cell? Had it been all the time he had courted me, in the clear light of Paris? ${ }^{56}$

After the discovery, she leaves the room and plans a way for escaping from the castle and her husband. She also attempts to call her mother to ask for help, with no result: 'My mother. I ran to the telephone; and the line, of course, was dead. Dead as his wives.'57 She is desperate and isolated from the external world, and tries to confess her experience to Jean-Yves, the young blind servant of the castle. He tells her the story of violence of that castle and the family that lived in it, describing the old legends of an earlier local Marquis who had hunted girls for amusement. The protagonist suddenly realizes that though she did not know the extent of the Marquis' evil, she had always known that sooner or later he 'would be the death of' her.

'I can be of some comfort to you,' the boy said.' Though not much use.' 'You do not deserve this,' he said. 'Who can say what I deserve or no?' I said. 'I've done nothing; but that may be sufficient reason for condemning me.' 'You disobeyed him,' he said. 'That is sufficient reason for him to punish you.' 'I only did what he knew I would.' 'Like Eve,' he said. 58

According to Manley, 'she despairs when Jean-Yves compares her to Eve, a woman often considered the first victim of curiosity. The bride feels as Eve did when God ordered her

\footnotetext{
56 lbid., pp. 132-133

57 lbid.

58 Ivi, p. 140.
} 
and Adam out of the Garden of Eden: she must obey. Once again, she oscillates between extremes: insecurity and uncertainty on the one hand and growing confidence on the other. ${ }^{59}$ In fact, when the Marquis comes back to the castle, she gives him the keys as soon as he asks them, as if she were preparing herself to face death. The Marquis, then, looks at the bloodstained key and realizes her disobedience.

That tell-tale stain had resolved itself into a mark the shape and brilliance of the heart. [...] That telltale stain had resolved itself into a mark the shape and brilliance of the heart. Then he sharply ordered: 'Kneel!'

I knelt before him and he pressed the key lightly to my forehead, held it there for a moment. I felt a faint tingling of the skin and, when I involuntarily glanced at myself in the mirror, I saw the heartshaped stain had transferred itself to my forehead, to the space between the eyebrows, like the caste mark of a brahmin woman. Or the mark of Cain. ${ }^{60}$

Again, this Biblical reference to Cain and the original sin, connected with the female sin of curiosity, are embodied by the stain on the forehead of the protagonist. As an allegory for betrayal, as Bettelheim would argue, as the red A for 'Adultery' sewed on the chest of Hester Prynne in Nathaniel Hawthorne's The Scarlet Letter, the protagonist will always expose the trace of her disobedience on her forehead. Furthermore, he lets her keep the choker of rubies while he is killing her, but asks back the ring he gave her when he asked her as a wife, given to his family by Caterina de' Medici: 'it will serve for a dozen more fiancées ... And now the key gleamed as freshly as if it had just been cut. He clipped it back on the ring, emitting that same, heavy sigh as he had done when I said that I would marry him. 'My virgin of the arpeggios, prepare yourself for martyrdom.' 61 This simple imperative utterance, thus, is the essence of the Marquis' fantasies on the narrator. Even now that she has betrayed his trust, that she has become his wife and has lost her virginity, she always represents the martyr woman who prepares herself to death with dignity. She is, in a certain way, for him, a reincarnation of Saint Cecilia's martyrdom, which makes me assume that he himself must feel identified with the tyrant judge who ordered Cecilia's death by decapitation. The act of killing itself becomes for the Marquis a new experience of courtship, as revealed by the rituals he obliges her to re-enact: 'What form shall it take?' I said. 'Decapitation,' he whispered, almost voluptuously. 'Go and bathe

\footnotetext{
${ }^{59}$ Manley, Kathleen E. B., The Woman in Process in Angela Carter's "The Bloody Chamber", quoted above, p. 86.

${ }^{60}$ Carter, Angela, The Bloody Chamber and other stories, quoted above, p. 139.

61 lbid.
} 
yourself; put on that white dress you wore to hear Tristan and the necklace that prefigures your end. And I shall take myself off to the armoury, my dear, to sharpen my greatgrandfather's ceremonial sword.' 62 Then, the finale is altered from its regular sequence of events: somebody interrupts the ritual of sacrifice, as the Marquis calls it, and saves the narrator. We could expect the brothers, as in the Perraultian version, but it is her mother indeed who saves her:

And--a great battering and pounding at the gate, the jangling of the bell, the frenzied neighing of a horse! The unholy silence of the place shattered in an instant. You never saw such a wild thing as my mother, her hat seized by the winds and blown out to sea so that her hair was her white mane, her black lisle legs exposed to the thigh, her skirts tucked round her waist, one hand on the reins of the rearing horse while the other clasped my father's service revolver and, behind her, the breakers of the savage, indifferent sea, like the witnesses of a furious justice. And my husband stood stockstill, as if she had been Medusa, the sword still raised over his head as in those clockwork tableaux of Bluebeard that you see in glass cases at fairs. [...] Now, without a moment's hesitation, she raised my father's gun, took aim and put a single, irreproachable bullet through my husband's head. ${ }^{63}$

After that experience, the narration passes to present time, when the protagonist lives in Paris, engaged with Jean-Yves, and living with her mother. The Marquis is dead and his bloody chamber locked to life. Nevertheless, her stain on her forehead remains, and she feels lucky that Jean-Yves is blind, for 'no paint nor powder, no matter how thick or white, can mask that red mark on [her] forehead. [She is] glad he cannot see it--not for fear of his revulsion, since [she knows] he sees [her] clearly with his heart--but, because it spares my shame. ${ }^{64}$

\subsection{Filling the blank page: female subjectivity in The Bloody Chamber}

As Karen Blixen tells in her tale The Blank Page, it is a custom for a Portuguese princess, when married, to expose her bloody sheets the morning after the wedding night, that would tell the citizens that she was a virgin. As a reward, the nuns that cared of the princess' education while she was at the convent receive a white piece of the sheets, a blank page, that would not tell anything about the princess' story, but that symbolizes the possibilities of the woman. As Susan Gubar argues, 'the bloody sheets symbolize the necessity for those women to use their own bodies to tell "their" story, and that story is the

\footnotetext{
62 Ibid.

63 Ibid., p. 142.

${ }^{64}$ Ivi, p. 143.
} 
one patriarchy wants to hear: that is, women's willingness to be "objects of exchange". These women are not, then telling their own stories. ${ }^{\prime 65}$ Carter's protagonist, on the contrary, is. She is far away from the passive heroine without voice blamed for curiosity represented by Charles Perrault's folktale, she has finally acquired the role of narrator and she is now telling us how the story goes, why she is pushed into opening the bloody chamber, what feelings she is experiencing, and how she acknowledges her husband is a murderer.

There is, throughout the novella, a gradual process of development of subjectivity that evolves anytime the young woman is confronting her experience with the one of another woman, may be that woman real or fictional. The first, and more explicit association, which I have already explained, is the one with Eve, the first of women, the sinner par excellence, and the whole novella can be considered as a way of Carter to redeem Eve's image. But, speaking chronologically, the first woman the narrator identifies with is Isolde. We notice that when she is invited by the Marquis to attend Wagner's Tristan, and she describes her romantic idea of love. She, in fact, experiences a girlish and cheap idea of love. ${ }^{66}$ She wants a love like the one of Tristan and Isolde. As Manley refers, 'In the opera, Isolde wishes death for herself and Tristan if he does not requite her love. Carter's Marquis desires death not for a beloved, but for a woman he wishes to control. ${ }^{67}$ However, 'though the blind lover Jean-Yves is apparently not the passionate one about which the young, romantic protagonist was once curious, like Tristan he is loyal, devoted and a lover who "sees me clearly with his heart". ${ }^{68}$ Another mise-en-abyme of her is Saint Cecilia. She links herself to her and, as she says, 'I saw myself as I could have wished to be' if she had not chosen marriage and were more self-confident about her musical skills. As we see, the Marquis gives her a portrait of Saint Cecilia as a wedding gift, as if he himself sees Cecilia's story inside her, including her martyrdom. ${ }^{69}$ Another interesting character, of course, her virago Mother. This woman, so different from her, at first asked her if she was sure about loving the Marquis at the point of marrying him. The protagonist, to that question, answers: 'I am sure I want to get married.' However, there is a change in perceptions for the narrator at the end of the story: the protagonist's stronger sense of subjectivity when the story ends allows her to choose for herself as her mother did, to

\footnotetext{
65 Gubar, Susan,'The Blank Page' and the issues of Female Creativity. Writing and Sexual Difference. Ed. Elizabeth Abel. Chicago: University of Chicago P, 1982. 73-93, from Manley, Kathleen E. B. , The Woman in Process in Angela Carter's "The Bloody Chamber", quoted above, p. 84.

66 lbid., p. 89.

67 Ibid.

68 Ibid., p. 90.

69 lbid., p. 91.
} 
choose love, so we can assume she will later experience a conduct similar to the one of her mother.

In addition, there is a literary element that I would like to consider as archetypical of the female agency in the narrative model of Bluebeard and its many variations I have here presented; namely, the bloody chamber itself. We are introduced to this mysterious, dark and forbidden room together with the female protagonist, and it is impossible, or should be, for us, to have access to it, although the husband-devil-wizard gives the lady the keys to any room of the palace, including the one for the mysterious, forbidden, little door. The American professor J. Hillis Miller, in his essay entitled 'Derrida's Topographies,' fournishes an interesting analysis on the French philosopher Jacques Derrida and his relationship, finding a way to apply the Derridian thought to literature and, in particular, Derrida's notion of the crypt. ${ }^{70}$ As he argues, 'every secret, it might seem, is hidden in some kind of crypt. "Secret" is Crypt's middle name, along with "Death" and "Cipher". ${ }^{71}$ Secrecy and the notion of the crypt are, then, deeply connected, and this corresponds perfectly to our idea of the bloody chamber. But, then, what does this mean for female subjectivity? Starting from the Greek meaning of the word 'symbol,' as being the 'broken half of a whole object,' this gives us the idea of an object missing the other half of their original completeness. In our case, the completeness is accomplished when the two halves, the lady and the bloody chamber, meet each other. While one of the two halves will permanently and irrevocably be incomplete, and this is the condition of secrecy of the crypt, the other half, the woman, is the only testimony we have that the crypt exists. She becomes a subject the moment in which she decides to disobey her husband's commands. The symbolic, Derridian half, becomes a whole when she enters the secret of the crypt. In other words, the crypt 'is also our only way of knowing anything about the cryptic enclosure as a place that is not a place, a place-no-place where events take place without taking place. ${ }^{72}$ And what about the other incomplete half? What is the secret of the bloody chamber that will not ever reach a wholeness? It is not the dead women, nor the tortures that happened inside, for sure. They represent the marginal secret, made explicit when the lady opens the door. The bloody chamber's untold secret is the murderer's true nature. We can look at what he did, but we cannot understand his ethics, and neither can his wife, and this is the reason why she must die like the others. Here's the secret of the crypt.

\footnotetext{
70 J. Hillis Miller, Derridean Cartographies, South Atlantic Review, 59, No. 1 (January 1994), pp. 1-25.

71 Ivi, p. 13.

72 lbid., p. 15.
} 


\subsection{The Marquis and the Sultan: masculinity and Orientalism}

The tendency to Orientalization of the murderous husband does not only belong to the Marquis of The Bloody Chamber, but is rather an element that seldom returns in his representation. I am not only talking about written versions of the Bluebeard's archetype, but also in iconography. For example, when in 1910 Edmund Dulac is asked to draw the illustration for the Contes by Charles Perrault, he decides to set the story of Bluebeard in an Arabic scenario. The characters are represented with Oriental clothes, wearing feathers and turbans and carrying scimitars. ${ }^{73}$ Furthermore, another interesting aspect is the attribution of a name to the unnamed female protagonist by Dulac, who calls her Fatima in the caption of a picture ("The unhappy FATIMA cried up to her: - Anne, Sister Anne, do you see anyone coming?'") In the next picture, Bluebeard prepares himself to behead his wife, holding the scimitar, the classic Arabic sword used for capital executions. In the last picture, when the brothers of Fatima come to save her from Bluebeard, he loses his turban, which is a sign for dishonor and unseemliness, a trace that suggests Dulac's adherence also to Arabic system of cultural values for his setting of Bluebeard. As Maria Tatar claims 'Beards were not fashionable in Perrault's time, and Bluebeard's monstrous growth of a shadowy color marked him as an outsider and libertine. The exotic beard inspired a number of interpretations that cast Bluebeard in the role of oriental tyrant. Edmund Dulac's illustrations set the tale in the Orient, with Bluebeard sporting a turban, while his wife lounges with other women in what appears to be a harem. ${ }^{74}$

As referred also by Marina Warner,

Beardedness divided the men from the boys in the Olympic Games; in Saint Augustine's view 'the beard signifies strong men; [it] signifies young, vigorous, active, quick men'. Beards were also the mark of the goat, and given the goat's lustful and diabolical character, its kinship with satyrs and other classical embodiments of lust, like the god Pan, and the Devil himself (he actually wears a bluebeard in fourteenth-century stained glass at Fairford church, Gloucestershire, beards came increasingly to define the male in a priapic mode. Orderic Vitalis, for instance, in the twelfth century, complained of the influence of the East -of the Saracen- on Norman fashions: 'Now almost all our fellow countrymen are crazy and wear little beards, openly proclaiming by such a token that they revel in filthy lusts like stinking goats.' [...] the cultures' contrasting oaths point up the difference in

\footnotetext{
73 Fig. 3.

${ }^{74}$ Tatar, Maria, The Annotated Classic Fairy Tales, quoted above, p. 145.
} 
value: Muslims swear by the Prophet's beard, Christians by the Savior's wounds (though 'zounds' is not much found today beyond the pages of Regency romances). ${ }^{75}$

There is, thus, a clear intention to associate the brutality of the killer of women to his attention and inclinations for the Oriental world. As we understand from a passage in The Bloody Chamber, the Marquis has an interest for collecting erotic printings. One of these refers to the Adventures of Eulalie at the Harem of the Grand Turk, so that now the double incarnation of the Marquis with both the Sadeian intellectual and the Sultan from the Arabian Nights is clear.

My mother, with all the precision of her eccentricity, had told me what it was that lovers did; I was innocent but not naïve. The Adventures of Eulalie at the Harem of the Grand Turk had been printed, according to the flyleaf, in Amsterdam in 1748, a rare collector's piece. Had some ancestor brought it back himself from that northern city? Or had my husband bought it for himself, from one of those dusty little bookshops on the Left Bank where an old man peers at you through spectacles an inch thick, daring you to inspect his wares ... I turned the pages in the anticipation of fear; the print was rusty. Here was another steel engraving: 'Immolation of the wives of the Sultan'. ${ }^{76}$

The hyperbolic charge of sexuality in the Marquis, included his blue exposed beard and his sexual exuberance during the act of penetration, tends to emphasize his virility, where he himself is the key and the wife his lock. According to Danielle M. Roemer and her essay The Contextualization of the Marquis in Angela Carter's "The Bloody Chamber", Carter's Marquis represents at the same time the incarnation of three Oriental despots, as the fourteenth-century warlord Timur/Christopher Marlowe's Tamburlaine, the sixteenth century Persian Shah Abbas, and the Parisian couturier Paul Poiret. Again, as Marina Warner argues, 'the phonological similarity if the French word barbe (beard) with the word barbare (barbarian) may have contributed, in the woodcuts of Perrault's first edition and continuing into an "Oriental, a Turk in pantaloons and turban, who rides an elephant, and grasps his wife by the hair when he prepares to behead her with his scimitar". ${ }^{77}$ Maria Tatar, instead, is the first to catch, among iconographic references (Arthur Rackham, Edmund Dulac) the parallelism between Bluebeard and the sultan Schahriyar, from the Arabian Nights' tradition, as he beheads one wife after another because of the discovery of his wife's sexual curiosity.

\footnotetext{
${ }^{75}$ Warner, Marina, From the Beast to the Blonde. From Fairy Tales to their Tellers, quoted above, p. 242.

${ }^{76}$ Carter, Angela, The Bloody Chamber and other stories, quoted above, p. 120.

77 Bacchilega, Cristina, Roemer, Danielle M., Angela Carter and the Fairy Tale, quoted above, p. 110.
} 
But the story of King Schahriyar and Scheherazade gives us a pronounced example of the way in which cognitive curiosity can be wedded to sexual curiosity. More important, it launches a tradition in which female curiosity is castigated as the death principle whereas male curiosity is celebrated as a liberating, life-giving force. In light of this Oriental legacy, it becomes all the less remarkable that examples of female curiosity are repeatedly accompanied by moral glosses in fairy tales, while instances of male curiosity stand as gateways to the world of high adventure. ${ }^{78}$

During the ritual of preparing the sacrifice of his wife, the Bloody Chamber's Marquis says: "'Oh, my love, my little love who brought me a white gift of music," he said, almost as if grieving. "My little love, you'll never know how much I hate daylight!"79 Just as the sultan Schariyar used to do, the Marquis as well is preparing to kill his courtesan, after having made her play the pantomime of the chastity that he had so meticulously prepared.

\footnotetext{
78 Tatar, Maria, The Hard Facts of the Grimms' Fairy Tales, Princeton University Press, 1987, p. 168.

${ }^{79}$ Carter, Angela, The Bloody Chamber and other stories, quoted above, p. 139.
} 


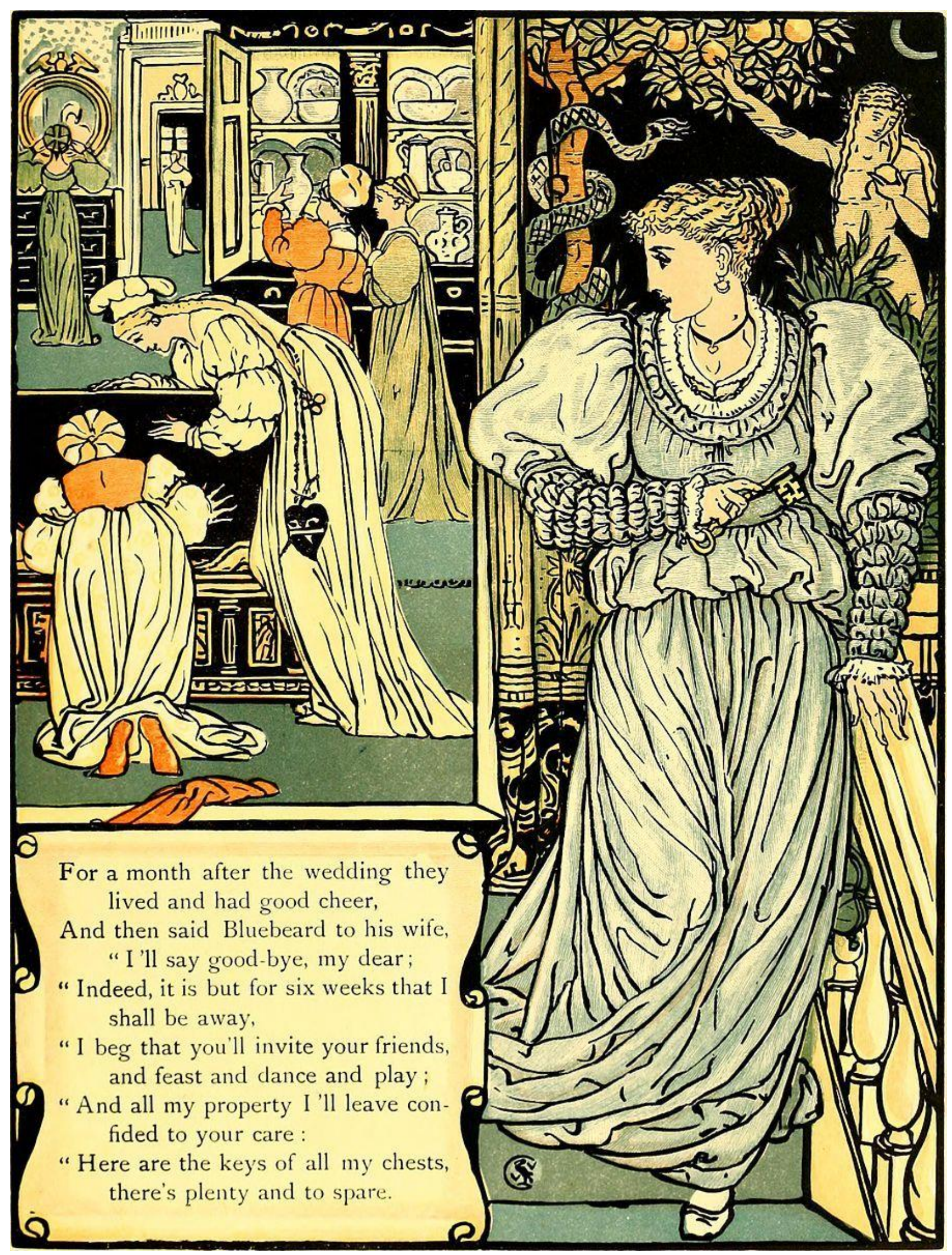

FIGURE 1. Walter Crane, Bluebeard's Picture Book: Containing Bluebeard, the Sleeping Beauty and Baby's Own Alphabet, London \& New York: John Lane, the Bodley Head, 1899. 


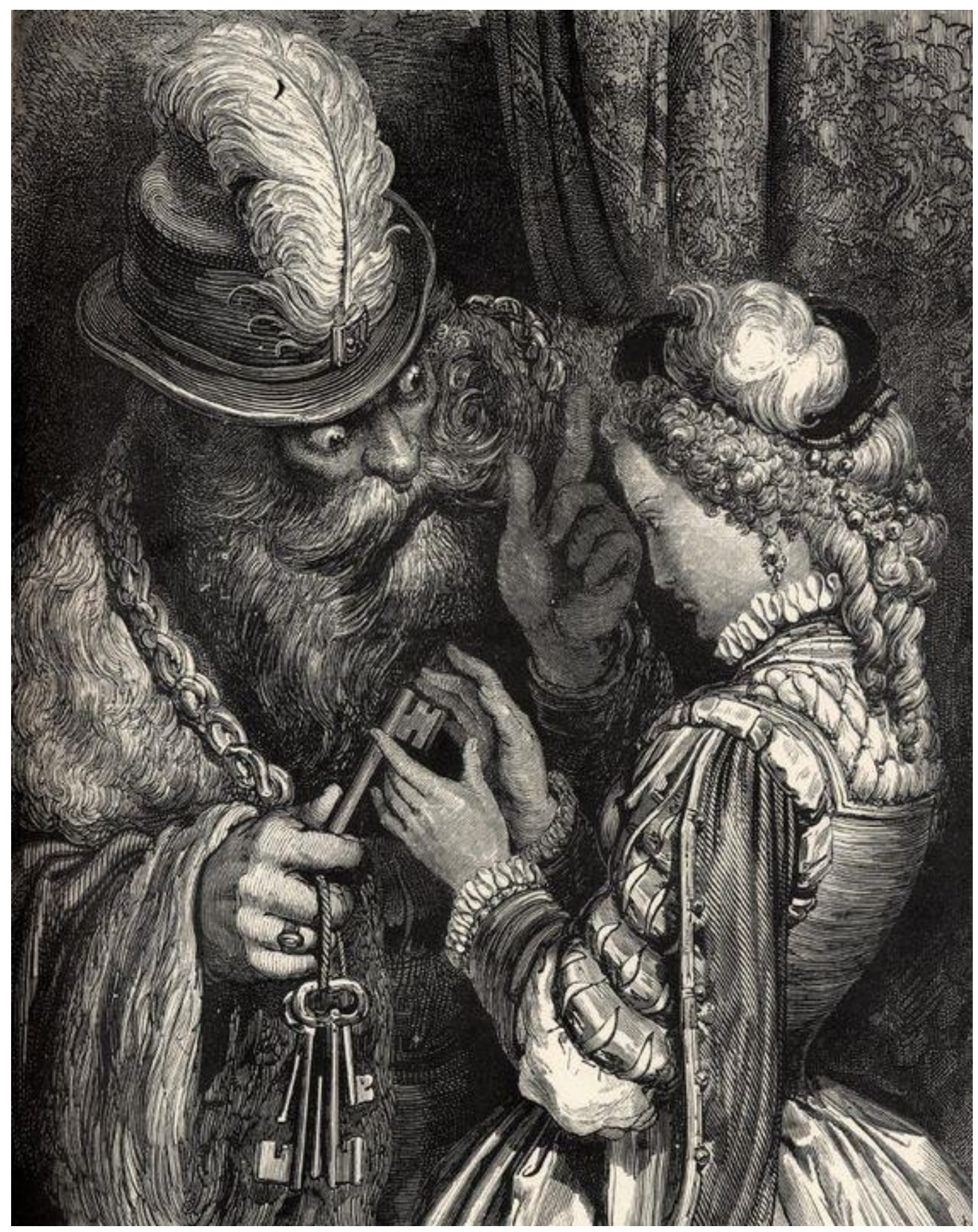

FIGURE 2. Gustave Doré, illustration for Contes de Ma Mere l'Oye, by Charles Perrault, 1862. 


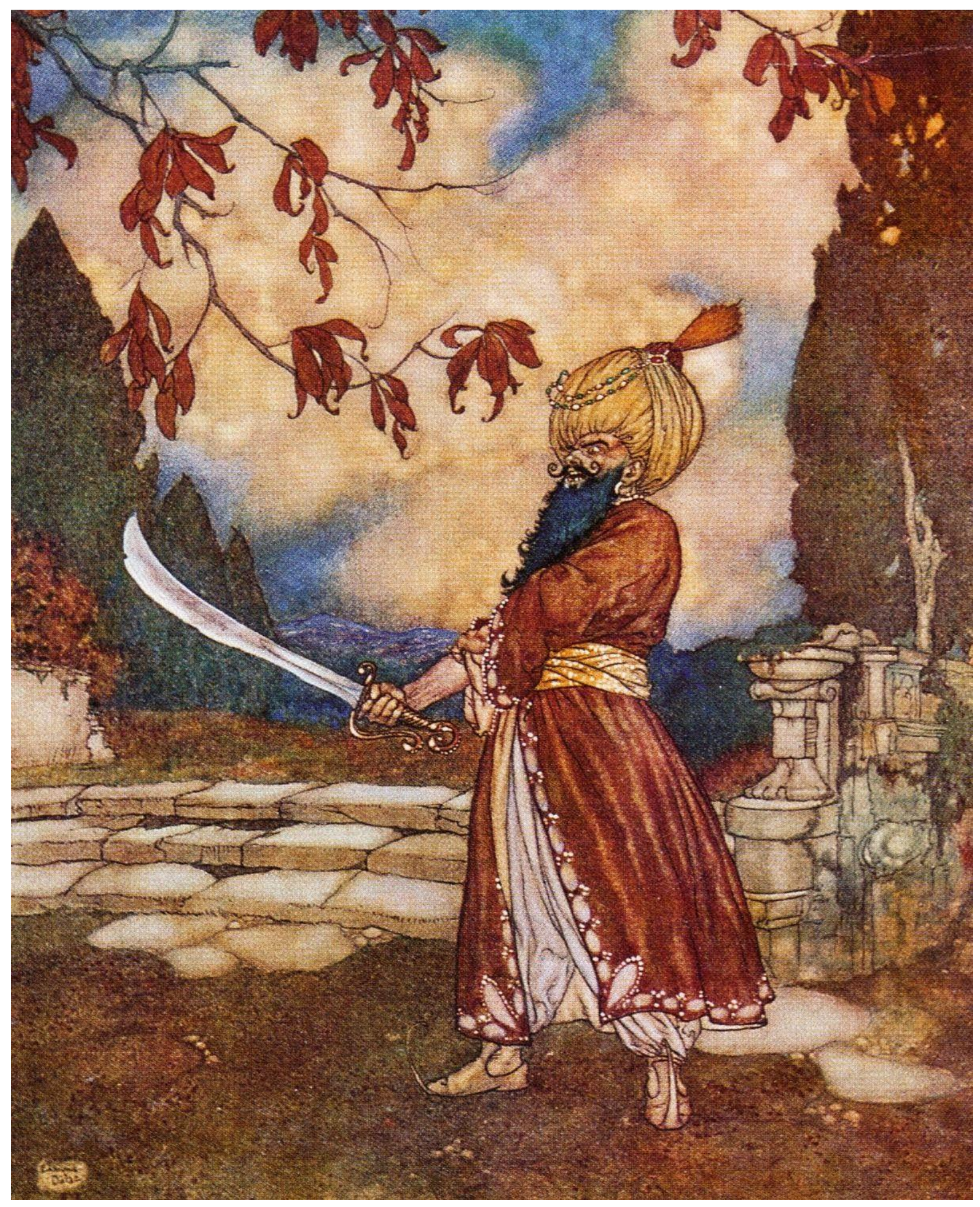

Figure 3. Edmund Dulac, Illustration for Bluebeard. Quiller-Couch, Sir Arthur. The Sleeping Beauty and Other Tales From the Old French. Edmund Dulac, illustrator. New York: Hodder \& Stoughton, 1910. 


\section{Chapter Two}

\section{The Traffic in Maidens: female alliances, wicked women and elements of kinship in the patriarchal territory of folktales}

\subsection{A woman must die}

In this chapter, I will show how important strategies of female alliance can be for the heroine of a tale and, at the same time, what are the limits of these strategies. There has always been a tendency to represent the relationship between women as wicked, never sincere and conflictual. This, according to the feminist American psychiatrist Janice Raymond, author of $A$ Passion for Friends, ${ }^{80}$ occurs because in a patriarchal system there has always been the necessity to look for a lack of cohesion among the female world, so that the power of the counterpart, the homosocial world, could vindicate its stability and its strength against women. These women, on the other hand, may have never really reacted to patriarchy because of the false assumption that a woman is an enemy for another woman. As Jonathan Swift said, quoted by Janice Raymond, 'I never knew a tolerable woman to be fond of her own sex.'81

Amongst the tales I have decided to take as case studies, some of them present a situation where a woman, sometimes older and with more experience than the protagonist, helps her to flee from a situation of oppression of sexual nature, and very often provoked by a man, a father or a brother who sexually desires the maiden and attempts to abuse of her virtue. Cristina Bacchilega introduced this narrative archetype as the motif of the persecuted maiden. ${ }^{82}$ This definition can be considered as an umbrella term if related to the folktale universe, as Cinderella, Donkeyskin, The Armless Maiden, Belle from Beauty and the Beast, Snow-White can all be considered as persecuted maidens, some because

\footnotetext{
80 Raymond, Janice G., A passion for friends: toward a philosophy of female affection. Boston / London / Munich: Beacon Press / the Women's Press / Frauenoffensive. Reprinted by Spinifex Press, Melbourne (2001).

$81 \mathrm{lbid}$, p. 103.

82 Bacchilega, Cristina, An Introduction to the "Innocent Persecuted Heroine" Fairy Tale, Western Folklore, Vol. 52, No. 1, Perspectives on the Innocent Persecuted Heroine in Fairy Tales (Jan., 1993), pp. 1-12.
} 
of their beauty (Cinderella, Snow White), some because they refuse the marital law and refuse the taboo of incest.

Donkeyskin, or Peau d'Ane, from the Perrault tale, is refusing to marry her father who sees in her the image of her dead mother, and in each version of the tale she is helped by an old woman to trick in many ways her father so that she can leave her house and look for a safer place. The Armless Maiden, or, in some versions, The Girl without Hands, is helped by female figures, the Virgin Mary in some versions, to take back her chopped hands and her agency. Cinderella is helped by her fairy godmother to obtain the appropriate clothes for the royal ball. There are some cases in which these archetypes overlap, as it happens with the contamination due to the oral transmission of tales, and incestuous desire can be found in some Italian version of the Girl Without Hands (La Penta Mano Mozza, from Giambattista Basile). ${ }^{83}$ On the other hand, however, female alliances in folktales can find their opposite correspondence in female antagonism, which occurs when women act wickedly against other women. They conspire to kill the protagonist who is going to become the new wife of the king, they substitute letters of love with sentences of death, they poison, they order the royal cook to serve the king the flesh of his children as meal. In this chapter I will try to give a historical justification to this representation of female wickedness as a counterpart of female alliance, and how this rivalry has been functional for the male system to culturally refuse the idea of coexistence between women.

In addition, talking about women who suffer because of male desire, I will analyze the relationships in the structure of kinship as a form of impediment for the agency of the female subject. If we observe this kind of tales, there is a familiar situation of corruption or destabilization that likely obliges the female protagonist to abandon her house to run away from an announced tragedy, but then, she cyclically happens to come back only in the ending, when a situation of stability and 'normality' has been re-established inside her family. For example, the incestuous father or brother has understood the aberration of his desires and has now repented of how he treated his daughter-sister, who forgives him and can come back to be part of the kinship system. How, then, can a sister, a daughter, a wife, choose for herself inside a dynamic where she is nothing but a gift, a product to exchange, a male desire to satisfy in a patriarchal logic of the tale? Is there a chance for the persecuted maiden to choose for herself?

${ }^{83}$ Basile, Giambattista, Lo cunto de li cunti, a cura di Michele Rak, VI ed., Milano, Garzanti, 2007. 


\subsection{The Snow Child and the embodiment of male fantasies}

The maternal feeling is the root of human community. [George Gilder, Sexual Suicide] ${ }^{84}$

The Bloody Chamber collection contains ten tales, and The Snow Child appears to be the sixth story from the collection. The title is an immediate recalling of the story of Snow White, and as we will see, there are actually some elements that make us think about the Grimm Brothers' story. However, I would suggest that even though this tale is connected to Snow White, at the same time it can be read as a sort of critical parable, a monumental apology against the imaginary of folktales and how it has been always functional to the reproduction of gender roles. The tale is very short, less than three pages, and the characters are perfectly functional to what Carter aims to represent: the male hero who desires a child, who saves the child from winter's cold and, at the end, reveals his corrupted desires. However, even though it is short, this tale may represent the key of interpretation for Carter's entire collection of tales. The passive, silent, beautiful little girl who is brought on the count's horse and who experiences violence without even deserving it, as in the archetype of the persecuted maiden; and, at last, the severe, cruel countess who rejects the presence of the snow child, perceiving her as a danger and constantly attempting to kill her to re-establish her supremacy as a dominating woman in her relationship with the count, her husband.

In 1974 Andrea Dworkin published her essay Woman Hating: A Radical Look at Sexuality. ${ }^{85}$ This essay, as basically the majority of feminist literary criticism texts belonging to the Seventies (think about Kate Millet's Sexual Politics, 1970) represents an essential revision of the male literary tradition and representation of the world of folktales and French erotic literature. The first section on folktales reflects on the relationships between women and the representation of a passive and active model of femininity. Although Dworkin's representation may appear essentialist and separatist as many feminist works of 60's and 70's may appear, nevertheless her analysis is functional to understanding how the dynamics of actions and roles in a folktale are based on a stereotypical, conservative image of society and common beliefs. Then, the representation of women in folktales appears as nothing but the general assumption on her role:

\footnotetext{
${ }^{84}$ Gilder, George, Sexual Suicide, Quadrangle, 1973.

85 Dworkin, Andrea, Woman Hating. New York: Penguin Books, 1974.
} 
malignant stepmother or angelical dead maiden waiting for her prince to awake her with a kiss. As Dworkin explains, 'Maternal love is known to be transcendent, holy, noble, and unselfish. It is coincidentally also a fundament of human (male-dominated) civilization and it is the real basis of human (male-dominated) sexuality.' 86 In order to be a good woman, one must be passive. Being active means to be malignant, and her actions are only functional to create damage to another character.

These fairy-tale mothers are mythological female figures. They define for us the female character and delineate its existential possibilities. When she is good, she is soon dead. In fact, when she is good, she is so passive in life that death must be only more of the same. Here we discover the cardinal principle of sexist ontology - the only good woman is a dead woman. When she is bad she lives, or when she lives she is bad. She has one real function, motherhood. In that function, because it is active, she is characterized by overwhelming malice, devouring greed, uncontainable avarice. She is ruthless, brutal, ambitious, a danger to children and other living things. Whether called mother, queen, stepmother, or wicked witch, she is the wicked witch, the content of nightmare, the source of terror. ${ }^{87}$

In the Snow-White type, we can assume that the hatred for the stepdaughter is generated when there is a particular kind of conflictuality: the triangle of desire between the two women (the wicked stepmother and the Snow-White girl) and the man (the king and SnowWhite's father) as object of desire. This would explain the wish for killing of the rival for the possession of the father that moves the agency of the evil queen. However, as Soman Chainani explains in his essay Sadeian Tragedy: The Politics of content revisions in Angela Carter's The Snow Child, ${ }^{88}$ this still does not represent a reasonable choice for aiming at Snow White's death, and the reason for the queen's hatred against Snow White must be found outside the text. As Sandra Gilbert and Susan Gubar claim, 'the relationship between a stepmother and stepdaughter is doomed because "female bonding is extraordinarily difficult in patriarchy: women most inevitably turn against women because the voice of the looking glass sets them against each other.' 89 Consequently, we can read

\footnotetext{
86 lbid., p. 38.

87 lbid., p. 41.

${ }^{88}$ Chainani, Soman, Sadeian Tragedy: The Politics of content revisions in Angela Carter's The Snow Child. Marvels \& Tales, Vol. 17, No. 2 (2003), pp. 212-235.

${ }^{89}$ Glibert, Sandra, and, Susan Gubar, The Madwoman in the Attic: The Woman Writer and the Ninetheenth Century Literary Imagination. New Haven: Yale UP, 1979.
} 
the voice of the looking glass as the attempt of the male cultural system to repeat a stereotypical assumption, which is: women cannot create relationships of alliance or complicity with other women. Plus, as the object of desire is the man, there is an idealization of the masculine subjectivity that looks at the female desire as functional to the male ego. The only choice for them is to fight against each other. This premise is necessary to understand some aspects of Carter's tale, as the story perfectly epitomizes the male imagery, or male gaze, on relationships between women and the same time it objectifies the female body in order to accomplish the masculine erotic fantasy.

The original story of Snow White begins with a beautiful queen sewing at a window and wishing for motherhood. Later, she dies and her husband marries another woman, who will become Snow White's rival. This is because the only role assigned to the good queen is to mother a child who will become the protagonist of the tale, and then to die.

[...] she pricked her finger with the needle, and three drops of blood fell on the snow. The red looked so beautiful on the white snow that she thought to herself, "If only I had a child as white as snow, as red as blood, and as black as the wood of the window frame!" Soon thereafter she gave birth to a little daughter who was as white as snow, as red as blood, and her hair as black as ebony. That's why the child was called Little Snow White. ${ }^{90}$

In 'The Snow Child,' there is an immediate subversion of the desiring subject, as it is the man, the Count, the one who wishes for a child who suddenly appears to take shape in front of him and his wife, the Countess. Carter's rewriting is faithful to Steven Swann Jones's definition of sequence in the Snow-White archetype: origin, jealousy, expulsion, adoption, renewed jealousy, death. ${ }^{91}$

Midwinter--invincible, immaculate. The Count and his wife go riding, he on a grey mare and she on a black one, she wrapped in the glittering pelts of black foxes; and she wore high, black, shining boots with scarlet heels, and spurs. Fresh snow fell on snow already fallen; when it ceased, the whole world was white. 'I wish I had a girl as white as snow,' says the Count. They ride on. They come to a hole in the snow; this hole is filled with blood. He says: 'I wish I had a girl as red as blood.' So they ride on again; here is a raven, perched on a bare bough. 'I wish I had a girl as black as that bird's

\footnotetext{
90 Grimm, Jacob and Wilhelm, The Original Folk and Fairy Tales of the Brothers Grimm, edited by Jack Zipes, Princeton UP, Princeton and Oxford, 2014, p. 170.

91 Jones, Steven Swann, The New Comparative Method: Structural and Symbolic Analyses of the Allomotifs of "Snow White", Helsinki: Academia Scientiarum Fennica, 1990, p. 22.
} 
feather.' As soon as he completed her description, there she stood, beside the road, white skin, red mouth, black hair and stark naked; she was the child of his desire and the Countess hated her. ${ }^{92}$

As can be seen, the style is clean and simple, there are no elaborated descriptions, nor an attempt to give psychological characterization. While the other stories in The Bloody Chamber push into the subjectivity of the female, concealed role of the tradition, here the tradition is re-enacted and destabilized. This style of writing, actually, represents the most explicit critique to the traditional models of folktales and to the conservative creation of gender roles. The length is the one of a classical fairy-tale, the introduction of the setting and the characters is immediate as the presentation of a traditional folktale would be. Even the colors are evoking a symbolic meaning: the Count, riding a grey horse, is the arbiter of the challenge between the women, while the Countess, riding a black horse, embodies an antithesis to the white field covered with snow, which is the cartographic womb that generates the Snow Child. The Countess is black and the maiden is white, evil and good in opposition. Even the fox furs that the woman is wearing are an archetypical representation of the femme fatale from Sacher Masoch and de Sade's works; as Chainani explains, 'she is positioned in the role of the sadist before the masochist is even born.'93 The Count spouts the three ritualistic desires for the creation of the perfect child, corresponding to his imagination of a little girl and, as there is no explanation for the Countess' hatred, we can perfectly assume that the repulsion against the child is due to her envy for her. The general idea, then, while reading this tale is that the evil one is the Countess, and that the Count seems protecting his child against the Countess' jealousy; this is probably the reason why the moment in which the girl dies and the Count rapes her dead body leaves us astonished.

Gollancz published Angela Carter's The Bloody Chamber and The Sadeian Woman in the same year, 1979.94 This let us assume that Carter's study of the Marquis de Sade's novels can be read as a commentary introduction to the reading of The Bloody Chamber, as if Carter is attempting to tell the reader: I am giving you examples of female passivity in literature, now you can read my tales and reflect on the role of my female characters. In particular, her interpretation of the dichotomy between Justine and Juliette in de Sade's

${ }_{92}$ Carter, Angela, The Bloody Chamber and other stories, quoted above, p. 193.

${ }^{93}$ Chainani, Soman, Sadeian Tragedy: The Politics of content revisions in Angela Carter's The Snow Child. quoted above, p.224.

${ }_{94}$ Carter, Angela, The Sadeian Woman and the Ideology of Pornography, 1978, Pantheon Books, London. 
Justine, or The Misfortunes of Virtue, followed by L'Histoire de Juliette, ou les Prospérités $d u$ vice. While Justine suffers any kind of injustice, is raped, tortured and accused of crimes she did not commit, and though she is still anchored to her Christian values, her sister Juliette takes advantage of sex, as a means to socially rise. As a matter of fact, in the end she appears to be rewarded by Fortune, becoming an important aristocrat woman, while Justine brutally deceases when she struck by a lightning that shots her to death. As Carter explains, 'if Justine is a pawn because she is a woman, Juliette transforms herself from pawn to queen in a single move and henceforward goes wherever she pleases on the chess board. ${ }^{95}$

What about the Countess and the Snow Child, then? Chainani provides an interesting interpretation of the count's desire that is functional to my discourse on the female-female hatred. Unlike the mother in the classical tale, the Count does not die after the Snow-White child is born, this means that he still has to accomplish his fictional mission. Second, pay attention to the utterances 'I wish I had a girl as white as snow/ as red as blood/ as black as that raven's feather. ${ }^{.96}$ Here, the simple past word "had" can be read in two ways, either the desire for the outcome of these three conditions or the realization of his sexual fantasies. This would mean that we should read the verb "to have" as "to sexually possess"; this would also explain the Countess' hatred, as she perceives the rivalry with the child of desire from the very beginning, from the moment in which her husband starts to wish for, not a daughter, but rather a silent concubine ${ }^{97}$ This is also the reason why the Countess would not feel any sense of motherhood for the child, as she is not the representation of a daughter in potentiality. The Countess is completely outside the male gaze of the Count, his ritual of fetishized embodiment. She is, then, the involuntary stepmother of the Snow Child, which brings her to wonder how to get rid of her. And while Justine and Juliette can coexist inside the universe of the novel, both representing a critique to the moral imposed to women (Justine) and a strategy of mockery to that very moral (Juliette), in Carter's tale this dichotomy is rather a conflictual tension, a fight for survival enacted by the Countess that wishes to annihilate the other woman. The Count's intervention inside the Countess' plot of revenge enacts the wish for death.

\footnotetext{
95 lbid., pp.79-80.

96 Carter, Angela, The Bloody Chamber and other stories, quoted above, p. 193.

${ }^{97}$ Chainani, Soman, Sadeian Tragedy: The Politics of content revisions in Angela Carter's The Snow Child., quoted above, p. 225.
} 
The Count lifted her up and sat her in front of him on his saddle but the Countess had only one thought: how shall I be rid of her? The Countess dropped her glove in the snow and told the girl to get down to look for it; she meant to gallop off and leave her there but the Count said: 'I'll buy you new gloves.' At that, the furs sprang off the Countess's shoulders and twined round the naked girl. Then the Countess threw her diamond brooch through the ice of a frozen pond: 'Dive in and fetch it for me,' she said; she thought the girl would drown. But the Count said: 'Is she a fish, to swim in such cold weather?' Then her boots leapt off the Countess's feet and on to the girl's legs. Now the Countess was bare as a bone and the girl furred and booted; the Count felt sorry for his wife. ${ }^{98}$

Notice the change of intentions from the first request of the Countess and the second. While at first she wants to leave the girl there while she picks up her glove, as soon as her husband intervenes she wishes for her death, asking the girl to look for the fur she voluntarily threw in the frozen pond. The husband arbitrates again, making her observe the absurdity of her asking, and in the meantime the Countess is seen as losing her power by losing her clothes, that are given to the child. And while at first it was the girl the one naked, now it is she. The Count's interference seems to break the relationship of power between Juliette (the Countess) and Justine (the girl); on the contrary, the Countess appears now as the woman lacking power. In the end, it is the Count the one who decides who is the one to win the challenge. As in the Snow-White type there is a three-episode ritualized action, here again the third request by the Countess is satisfied. As in the SnowWhite time, a natural element represents the defeat of the maiden; while in the Grimms version it was a poisoned apple, here we have a stinging rose: 'They came to a bush of roses, all in flower. 'Pick me one,' said the Countess to the girl. 'I can't deny you that,' said the Count. So the girl picks a rose; pricks her finger on the thorn; bleeds; screams; falls. ${ }^{99}$ Here, however, instead of a posthumous contemplation of the corpse of the maiden, waiting for a savior prince who comes to kiss her to break the spell, there is no hope for a mainstream ending, here Carter is exhibiting the Countess' triumph. Indeed, the Countess is again wearing her furs and her boots. The Count, for his part, has no intention to leave his primary objective for the creation of the child unsatisfied. He 'got off his horse, unfastened his breeches and thrust his virile member into the dead girl. The Countess reined in her stamping mare and watched him narrowly; he was soon finished. Then the girl began to melt. Soon there was nothing left of her but a feather a bird might have dropped; a bloodstain, like the trace of a fox's kill on the snow; and the rose she had pulled

\footnotetext{
${ }^{98}$ Carter, Angela, The Bloody Chamber and other stories, quoted above, p. 193.
}

99 Ibid. 
off the bush.' ${ }^{100}$ This escalation of the events is functional to present the Count's sexual imagery on women: one allied, malignant and powerful; the other, subservient, loyal, soundless, which perfectly corresponds to the dichotomy presented by Dworkin in her Woman Hating. The ending scene presents a situation of re-establishment of power for the Countess, and the attempt for the Count to obtain again his wife's trust.

Then the girl began to melt. Soon there was nothing left of her but a feather a bird might have dropped; a bloodstain, like the trace of a fox's kill on the snow; and the rose she had pulled off the bush. Now the Countess had all her clothes on again. With her long hand, she stroked her furs. The Count picked up the rose, bowed and handed it to his wife; when she touched it, she dropped it. 'It bites!' she said. ${ }^{101}$

The Count picks up the same rose that killed the Snow Child and gives her, as a symbol of his love. Rather, as the most common allegorical symbol of romantic love in literature. As Chainani shows,

the Count effectively asks his wife to renew her position as his Juliette, as his sexual partner that trades intercourse for class benefits. But in hastily offering it to the Countess and in her acceptance of the gesture, neither of them recognize that the rose not only still carries the stigma of a murder weapon, but its symbolic power has been replaced with the allegorical, metonymic power of the martyred child. The countess drops the rose in shock: "It bites!" she exclaims. ${ }^{102}$

What I find interesting while looking at folktales and conflicts between women is the discourse concerning kinship and family. As Dworkin says, the nuclear structure is the first space where dynamics of patriarchal power are expressed, and women are only functional to revalidate the law of the father and the law of the husband. ${ }^{103}$ In this literary genre, that produces stereotyped models of behavior, I see the wicked woman as the product of a common belief according to which there is no chance for a female coexistence. There is a war amid the same sex, and as a genre that produces positive characters as opposite to negative ones, the evil queen must die.

\footnotetext{
100 lbid.

101 lbid.

102 Chainani, Soman, Sadeian Tragedy: The Politics of content revisions in Angela Carter's The Snow Child., quoted above, p. 228.

103 Dworkin, Andrea, Woman Hating. New York: Penguin Books, 1974, p. 40. 'The nuclear family, as we find it delineated in fairy tales, is a paradigm of male being-in-the-world, female evil, and female victimization. It is a crystallization of sexist culture - the nuclear structure of that culture.'
} 
In Giambattista Basile's Sole, Luna e Talia (Sun, Moon and Talia), ${ }^{104}$ probably the first European version of the Perraultian La Belle au Bois Dormant (The Sleeping Beauty), a king discovers a beautiful maiden sleeping an enchanted sleep in her palace into the woods, and his desire for her is so strong that he has a sexual intercourse with her while she is asleep. From this rape, that will be romanticized in later versions of the tale as the awakening, immaculate kiss of the savior prince, will be born two children, Sole and Luna, who will feed by themselves while sucking their mother's breasts and who will awake her from her eternal sleep while sucking her thumb, where there was stuck the flax bone that once stung her and brought her in her status of semi-death. When the king finds her awaken, surrounded by her children, he immediately decides to bring her at his palace as his new queen. There is only one little obstacle to their perfect, romantic happy ending: the king is already married to another woman, who burns in rage and envy when she faces the newly arrived bride and her kids. Then she plans a revenge, and from here Basile presents her as an absolutely evil character, while defining her as a 'Medea's heart,'105 which basically means that the woman is a cruel, outrageous and bloody witch. In the Perraultian version, the type of the envious wife is substituted with the envious mother of the Prince and her malice is reinforced by her monstrous origins: she is said, in fact, coming from a family of ogres.

The Queen said to her son several times, in the hope of drawing him out, that one should enjoy oneself in life, but he never dared to entrust her with his secret; although he loved her, he was afraid of her, because she came from a family of ogres, and the King had married her only because of her great wealth. It was even whispered at court that she herself had ogreish tendencies, and that when she saw small children going by she found it almost impossible to prevent herself from jumping on them, which is why the Prince would never say anything. But when the King died, which happened after another two years, and the Prince was in command, he made his marriage public, and went in a grand procession to fetch the Queen his wife from her castle. 106

\footnotetext{
104 Basile, Giambattista, Lo cunto de li cunti, a cura di Michele Rak, VI ed., Milano, Garzanti, 2007, quoted above, p. 422.

105 Ibid., p. IV 'Another technique for engaging polemically with convention is found in the intertextual references woven through the tales, which generally serve to bring the themes, characters, and language of the "illustrious" traditions of classical antiquity or the Renaissance down to the level of everyday-(albeit fairy-tale) - reality and frequently to laughable parody. For example, in "The Myrtle" a prince attacks a group of envious courtesans who have tried to end his beloved fairy's life: "with the heart of Nero and the cruelty of Medea, [you] made an omelet of that pretty little head and minced up these lovely limbs like meat for sausage.' Nero and Medea, emblems of ferocious cruelty, here give added force and solemnity to the prince's imprecations - at least until the courtesans' evil actions are likened to those of an overzealous cook.' 106 Perrault, Charles, Contes de ma mere l'Oye. The Complete Fairy Tales, translated by Christopher Betts, Oxford University Press Inc., New York, 2009, quoted above, p. 93.
} 
In the version by Giambattista Basile, instead, the necessity for substitution of the evil queen is given by her infertility, which justifies both the king's sexual extramarital relationships and the queen's wish for death of the children. Actually, as soon as the former Sleeping Beauty and her children are brought to the castle, she immediately plans to make her burn as a witch on the stake and to have her children butchered, cooked and served to the king, but the court's cook replaces the kids with two lambs. In Sole, Luna $e$ Talia, the dialogue between husband and wife during the king's "cannibalistic" mealtime acquires a very significant value.

\begin{abstract}
While the king was eating with great gusto, too, and exclaiming, 'Oh, on the life of Lanfusa, this dish is so good! Oh, on the soul of my grandpa, this other one is so tasty!' she kept on saying, 'Eat up, for you're eating what is yours.' The king paid no attention to this refrain two or three times, but finally, when he heard the music keeping up, he answered, 'I know that what I'm eating is mine, since you didn't bring a thing with you to this house!' and he got up angrily and went out to the nearby countryside to unleash his anger. ${ }^{107}$
\end{abstract}

While she is trying to tell him that he is devouring his own children, he answers that she didn't 'bring a thing with [her] to [that] house!'108, which essentially is an accusation for not having been able to become a mother, so he is basically blaming her for being sterile.

Talia, on the contrary, is embodying the perfect paradigm of the passive woman suggested by Dworkin. She was raped for the king's pleasure while under the sleeping spell, she mothered two twins without even emotionally participating in the moment of birth for she was in a coma, though this suggests that Talia is fertile and can bring a breed to the king, so she is the perfect, positive example of what a good wife should be. And when the king decided that the moment had arrived for her to be presented to the court, she only obeyed to her rapist love and followed him to castle. In fact, as soon as the evil queen faces her, insulting Talia because she has compromised her equilibrium and her societal wealth, Talia explains her version: '[...] she began to apologize, saying that it wasn't her fault and that the king had taken possession of her territory when she was under a sleeping spell. But the queen, who had no intention of listening to excuses, had a huge fire lit right there in the courtyard of the palace and then ordered that Talia be thrown onto

\footnotetext{
107 Basile, Giambattista, Lo cunto de li cunti, a cura di Michele Rak, VI ed., Milano, Garzanti, 2007, quoted above, p. 424.

108 Ibid.: '[...] 'I know that what I'm eating is mine, since you didn't bring a thing with you to this house!' and he got up angrily and went out to the nearby countryside to unleash his anger.'
} 
it.» 109 Of course, we are used to the triumph of the positive model, ad we can imagine there will be a happy ending. But, in order to make that possible, one of the women must die, and only by facing her literary destiny the wicked queen will lead the good maiden to live happily ever after; I would call it a necessary sacrifice. Necessary to what? To reaffirm the production of conservative models of behavior and to give a moral value to the actions of the female character, which will be shared by the community. The death of the queen shows how her position is not equalitarian to the one of the king and, rather, the king can decide her death or life. She is just something more than an ordinary wife, and can be replaced at any time. Marina Warner defines wives as 'passage hosts' in the house of men. ${ }^{110}$ It is not so difficult to imagine how this notion was deeply related with the public sphere and with the microcosm of marriage. Think about the fact that only in 1833, with the Dower Act, in England, for the first time a wife could ask for a life interest, after the death of her husband, to one-third of the lands owned by the husband at any time during the marriage. Before then, she was considered legally irrelevant in front of the law. The queen is defending, with immoral means, her privileged condition, she has no belongings but her marriage with the king to sanction her advantages, and Talia represents a crisis for her status in this regard.

Each version I took in exam of the Sleeping Beauty type ends with the evil queen dying and the princess living. Talia is immediately presented as the one who will triumph, as she accomplished her natural scope, which is to be a mother, while the wicked, infertile woman, who attempted to her life, will pay for her fault. As soon as the king discovers the plot of his former wife, he sentences her to death:

O renegade Turk, what kind of a ferocious thing did you do? Just wait; you're going to end up as compost in a broccoli plot, and I won't be sending this face of a tyrant to the Colosseum for her penance!' And as he was saying this he ordered that she be thrown into the same fire lit for Talia, together with the secretary who had been an instrument in the bitter game and a weaver of the wicked plot. ${ }^{111}$

Both the evil woman and the good one are products of the heteronormative imagery, and this is still the case as regards the conflict between women. As I will explain, an alliance

\footnotetext{
109 lbid.

110 Warner, Marina, From the Beast to the Blonde. From Fairy Tales to their Tellers, 1994, Vintage, New York, pp. 227-228.

111 lbid., p. 425.
} 
between women who help other women to escape from gender violence is considered as possible only when the woman who helps is no more considerable as being part of dynamics of desire that may affect them. Concisely, the helper can either be a sacred, mystical woman, as in the case of the fairy godmother's type or an old, wise woman, who can no more be a mother and thus is no more functional to the hetero-relational system of patriarchy. On the contrary, she can now be useful by helping spontaneously the young maiden in distress.

Another tale from Basile's collection is The Little Slave Girl (La schiavottella), which seems to be a variation of the motif of the Sleeping Beauty with elements from the archetype of the persecuted maiden. As the prologo shows,

Lisa is born from a rose petal and then dies because of a fairy's curse. Her mother puts her in a room and gives her brother instructions not to open it. But his jealous wife wants to see what is in there, finds Lisa alive, and, after dressing her as a slave, makes her suffer a thousand torments. She is finally recognized by her uncle, who drives his wife away and arranges the richest of marriages for his niece. ${ }^{112}$

Notice here a detail: the curiosity to open the bloody chamber is a feeling moved by the jealousy of the wife of Lisa's brother, and when she discovers that there is a young girl hidden in the room she uses her as a slave, making her experience pain. The woman in the bloody chamber is her enemy, and she must pay for her innocence and passivity. Then, she decides to humiliate her beauty while adopting the girl as a slave.

\footnotetext{
When she saw this beautiful creature the jealous woman immediately said, 'Good boy! For the life of me! "Key on the belt and Martin inside!" That's the reason for all this diligence about not opening the room, so that no one would see the Mohammed that he was worshiping in the caskets!' Saying this she grabbed the girl by the hair and pulled her out, and as she did so the comb fell to the ground and the girl came to her senses, screaming, [...] as full of poison as a serpent, she immediately cut off Lisa's hair, gave her a juicy beating, put her in a ragged dress, and every day unloaded lumps on her head, eggplants on her eyes, brands on her face, and gave her a mouth that looked like she had eaten raw pigeons. ${ }^{113}$
}

In 1986, the American lesbian feminist, psychiatrist and professor emerita of the University of Minnesota, Janice Raymond, wrote her essay A Passion for Friends: Toward a

\footnotetext{
112 Ibid., p. 180.

113 Ibid., pp.181-182.
} 
Philosophy of Female Affection, where she explores how the reproduction of female reciprocal hatred has become a cultural pattern, reproduced through the discourse and become a general assumption; in other words, gyn/affection, which corresponds to Raymond's definition for the creation of relationships between women, has always encountered an obstacle, it has always been polluted by this conjecture. She opens her essay showing how Jonathan Swift's postulation 'I never knew a tolerable woman to be fond of her own sex' has been reproducing similar views until nowadays, and when Raymond interviews women she notices a tendency to consider female friendship as a temporary status, not as something relevant for their lives, but rather as something belonging to a wish for extending the duration of a pre-womanhood, as if friendship and adulthood weren't compatible, couldn't coexist. 'A study chronicling women's attitudes toward female friendship revealed the following. From a secretary: "To attach too much importance to friendship with women is adolescent"; from a computer programmer: "It will be viewed as 'latent' lesbianism." It would be easy to ignore these voices by saying that women internalize men's attitudes about them and about their relationships with other women. ${ }^{114}$

Women, thus, as Raymond explains, have internalized through culture and through the male discourse all the stereotypes about gynosociality and folktales represent the perfect field for the creation of social examples. As Raymond explains,

By blaring the hetero-relational message that "women are each other's worst enemies," men have ensured that many women will be each others' worst enemies. The obstacles to female friendship get good press. The message functions as a constant noise pollution in women's lives and is heard in many different places. Constant noise about women not loving women is supplemented by the historical silence about women always loving women. Women-hating-women take their sustenance from the silence that surrounds women-loving-women. It is this double message that strangles the growth of Gyn/affection. Women need to be aware of the contexts in which this double message arises as well as the mechanics of how it functions to stonewall the evolution of female friendship. ${ }^{115}$

\footnotetext{
114 Raymond, Janice G., A passion for friends: toward a philosophy of female affection. Boston / London / Munich: Beacon Press / the Women's Press / Frauenoffensive. Reprinted by Spinifex Press, Melbourne (2001), p. 103.

115 lbid.
} 


\subsection{Runaway girls: tales of renegade daughters, incestuous men and chopped hands}

What about women loving women, then? As I said, in the universe of folktales this occurs only in situations where there is no advantage for the helping woman to provoke damages to another woman; there is no object of desire to be shared. Therefore, the old lady is always ready to provide strategies to the girl in order to avoid violence. There is a cyclical structure in this kind of tales taking about persecuted maidens who escape from the nuclear family. As a matter of fact, the persecuted maiden is the perfect field of representation of the cyclical path of the girl. She resists by running out from family, which has become for her a dangerous space. In folktales belonging to the tradition of Donkeyskin (in Italy we may find the story of L'Orsa by Giambattista Basile, Maria di Legno, by Italo Calvino, and Doralice, by Giovanni Francesco Straparola), there is a change of the initial status that brings the young girl to find new places of safeness, as her family is no longer a safe place. This change of status may be given by two main consequential factors: the death of the mother of the female protagonist, who makes the husband swear he will never marry anyone less beautiful than her, and the incestuous desire of the king for his daughter, as she represents the perfect resemblance with her mother, so that nobody could be compared to her. Being as beautiful as her mother was becomes a fault, which must be atoned while escaping. The strategy of resistance is at first enacted by the daughter, advancing impossible requests to the king-father, like clothes made with magic textures, like clouds and rays of sun. And later, when she recognizes there is no chance for her to avoid marriage, she disguises and runs away. Here, she finds the help of the old, wise woman who tells her to run away. In the Perraultian version, the old woman is her grandmother: 'She said, on seeing her: 'My dear, I know why you're so sad, and why you're here, But now you're with me, have no fear. Nothing will do you harm, provided that you will let yourself be guided by my advice. Your father, it is true, Has said he wants to marry you.'116 In other versions, like the Neapolitan L'Orsa, the old lady reveals to be a sorceress, who helps the young woman to acquire animal appearances, by giving her the chance to become a She-Bear at any time she will want. There is, also, a tradition which includes another way of escaping, where the old lady suggests entering inside a wardrobe (like in

\footnotetext{
116 Perrault, Charles, Contes de ma mere l'Oye. The Complete Fairy Tales, translated by Christopher Betts, Oxford University Press Inc., New York, 2009, p. 59.
} 
Doralice, from Giovanni Francesco Straparola) or a dress made of wooden. ${ }^{117}$ In the German version of the Girl Without Hands' tradition, Das Mädchen ohne Hände, by Grimm Brothers, the theme of incest has been substituted with the girl being given from the father as a gift to the devil, that has made her father become rich. This is because, as Sharon Rose Wilson ${ }^{118}$ explains, the Grimms sort of 'cleaned up' traditional folktales from all those elements which would have been considered as immoral and obscene for a young audience, including incest. ${ }^{119}$ As a matter of fact, we can assume that the first source for both the story of the Donkeyskin tradition and the Girl Without Maiden is commonly shared, and it can be found in the story of the dramatic religious representation of Saint Uliva, transcribed by Alessandro d'Antona. ${ }^{120}$ Here, Saint Olive from Palermo experiences all kinds of violence and brutality, but it all starts because her father is in love with her. As an act of protest, she cuts off her hands and sends them to the king as a wedding gift, and when he sees this act he sentences her to be thrown in the sea. This beginning is also shared by Basile's version of the story, La Penta Mano-Mozza (lit. Penta whose hands were chopped off). Here, it is Penta's brother who wishes her as a wife, and she refuses by mutilating herself and sending her brother her hands as a gift. ${ }^{121}$

However, the runaway maiden's cyclical path seems to represent a cultural representation of the model of the structure of kinship suggested by Levi Strauss in his essay The Elementary Structure of Kinship, and commented later by Gayle Rubin with her essay The Traffic in Women. ${ }^{122}$ As Levi-Strauss claims, marriage represents the main process for the construction of a generation. A woman who goes from a tribe to another represents the point of conjunction between these two tribes, and by giving birth to children she biologically would connect the tribes. Marriage is, basically, a gift transaction, However, she remains the passive object of exchange of a male quasi-mystical process of union, in which she has no role. Marriage, in other words, would give a concrete example to what Rubin defines the sex/gender system, as "a "sex/gender system" is the set of

\footnotetext{
117 Disguise and escape will be two aspects I will deal with in the third chapter of my essay, concerning with women wearing male clothes.

118 Wilson, Sharon Rose, Margaret Atwood's Fairy Tale Sexual Politics, University Press of Mississippi, 1993.

119 Ibid., p. 140.

120 Vesselovskij- Sade, La fanciulla perseguitata, 1970, Milano, Bompiani.

121 Basile, Giambattista, Lo cunto de li cunti, a cura di Michele Rak, VI ed., Milano, Garzanti, 2007, quoted above, p. 214.

122 Rubin, Gayle, The Traffic in Women: Notes on the 'Political Economy' of Sex, Ismael Books, United, 1975.
} 
arrangements by which a society transforms biological sexuality into products of human activity, and in which these transformed sexual needs are satisfied.'123 The girl who does not want to respect the sex/gender system and become the object of male fantasies reacts by leaving her home; she is now acting eccentrically from her gender role. However, this eccentricity cannot represent a new eternal condition, as a woman who is not pertinent with the male system could not represent a positive model, then her eccentricity must be re-absorbed from that very model. It happens, then, that she meets another man during her runaway path, a king in Grimms' version, who marries her and makes her pregnant. Only after that she has become a woman, by becoming a wife and a mother, and only after she has concluded her eccentric experience of runaway, there is the chance of a reconciliation between her and her incestuous father/brother, who has, in the meantime, apologized for his perverse desire. We see this happening in Basile's Penta. The king of Dry Rock, who is Penta's brother, is confessing his guilt in front of the king of Green Earth, Penta's husband. See the symbolism between Dry Rock, negative example of masculinity, associated with the sterility of an incestuous union, and Green Earth, immediately evoking prosperity, fertility, parenthood, and thus a positive example of masculinity. As LeviStrauss explains, in the world of tribal marriage

The prohibition on the sexual use of a daughter or a sister compels them to be given in marriage to another man, and at the same time it establishes a right to the daughter or sister of this other man.... The woman whom one does not take is, for that very reason, offered up [...]

The prohibition of incest is less a rule prohibiting marriage with the mother, sister, or daughter, than a rule obliging the mother, sister, or daughter to be given to others. It is the supreme rule of the gift. ${ }^{124}$

In other words, before being an ethical paradox, incest is not functional to the economy of two men that must create bonds of kinship with other members belonging to other tribes, legitimated by the exchange of women.

After Penta has heard all her brother's confession, hidden behind the same room, she appears for the final agnition:

Having heard the whole conversation from behind the door, Penta now came out. And, like a little dog that has been lost for many days and then finds her master and barks, licks, wags her tail, and

\footnotetext{
123 Ibid., p. 159.

124 Levi-Strauss, The Elementary Structures of Kinship, (1947 original ed.), p.51; p. 148.
} 
gives him a thousand other signs of her happiness, so she ran first to her brother and then to her husband, first pulled by the affection for the one and then by the blood ties to the other, and she embraced first this one and then that one with such jubilation that it's impossible to imagine: let's just say that they put on a three-part concert of truncated words and interrupted sighs. ${ }^{125}$

Notice how Basile is here giving a moral relevance to blood ties, which even in front of incestuous violence cannot be rejected. And so we can notice what has happened: the passive exchange of the bride from a tribe to another. Penta left her house because otherwise she would have encountered her brother's rape, but her flee couldn't run any longer, and after that she marries the man she loves, it seems as a physiological process to come to terms with the man of her previous family, her previous "owner", her brother/father. It has occurred the same thing that happened with the tribes described by Levi-Strauss: the gift has been blessed with the rejection of the incestuous desire and with the forgiveness of the magnanimous woman. The escape of the maiden, then, becomes only partially an act of resistance, as in the end the woman must always come to terms with the male rules.

125 Basile, Giambattista, Lo cunto de li cunti, a cura di Michele Rak, VI ed., Milano, Garzanti, 2007, quoted above, p. 223. 


\section{Chapter Three}

\section{Body of evidence: women in male disguise and interferences in the homosocial sphere}

La nostra condizione di omosessuali, tuttavia, la nostra ambiguità sessuale, il tipo di equilibrio raggiunto in noi tra connotati soggettivi e connotati del rimosso,

è tendenzialmente ermafrodito, è espressione di transessualità; mentre negli etero l'assunzione da parte del «soggetto» dei connotati dell' «oggetto» omosessuale rimosso porta a una doppia ruolizzazione, all'essere più maschio da parte del maschio, ruolizzazione normalissima che la lotta

femminista e omosessuale finirà col fare esplodere, al fine di liberare la transessualità loro e la nostra che essi reprimono. Se la dialettica tra i sessi e tra le tendenze sessuali si svolge in superficie, essa coinvolge contemporaneamente un gran numero di strati sottostanti ignoti. II movimento delle donne e il movimento gay apprestano quel terremoto che provocherà il crollo dell'intera struttura patriarcale.

[Mario Mieli, Elementi di critica omosessuale, 1977] $]^{126}$

\subsection{The Shift of Sex}

In folktales, as we have already seen, desire is always subordinated to ethics. There is no way for a character, man or woman, to imagine a happy ending that could diverge from the moral law. The oral origin itself of folktales, in fact, cannot simply be limited to the role of a general entertainment, but rather they were used to create social models of behavior. The young girl deviating from the path that brings her to the house of the grandmother meets the wolf that will eat her, all those characters who make damages to someone will logically receive a payback. There is, I would say, a system of values that can be easily compared to the Greek notion of kalòs kaì agathòs, beautiful and kind. We understand, then, how the heteronormative scheme can find a fertile field in fairy tales. In this chapter, what I want to

\footnotetext{
126 Our condition of being homosexuals, however, our sexual ambiguity, our kind of equilibrium reached inside us between subjective and removed connotations, is basically hermaphrodite, it is an expression of transsexuality. While among heterosexuals the adoption by the "subject» of the homosexual «object»'s connotations brings to a double rolization, it brings the male to act more manly, and this is a very common rolization that the feminist and queer movement will break down, in order to free their and ours transsexuality that is still repressed. If the dialectics between sexes and sexual orientations is happening on an aboveground level, it includes at the same time a great amount of underground and unknown levels. The female gay movements are bringing the earthquake that will bring the entire patriarchal structure to collapse. (my translation).
} 
focus on is the role of crossdressing in folktales as related to female characters. How does it impact on female identity? What are the limits of this disguise? Can a woman experience freedom once she is wearing male clothes? Can desire find its way when a subject renounces to the identity she or he was comfortable with before wearing a new one? The tales I have decided to use as case studies in this chapter clearly answer to these questions. In The Three Crowns by Giambattista Basile, as in Costanza and Costanzo from The Facetious Nights by Giovanni Francesco Strapaola, to become a man means to deliberately abandon any chance to be part of a marital union, and at the same time it represents for women a chance to cover roles they could never cover in any other way but being a man.

In her recently published essay, Figlie del padre (Father's daughters), ${ }^{127}$ professor Maria Serena Sapegno explores the many declinations of the father-daughter relationship in literature. While talking about Greek mythology, she mentions the episode of Athena's birth as the perfect embodiment of the father's desire. After the union with Metis, goddess of Prudence, Zeus is concerned about the prophecy that a son more powerful than him could be born and could annihilate him. Thus, he transforms Metis into a fly and he swallows her. But the goddess has already conceived Athena and she has given her an armor to defend herself once she will be born. When Hephaestus opens Zeus's head to help Athena to come out, she represents the perfect realization of a father's desire. As Sapegno explains, not only Athena has no mother, as her mother is erased and her education must be considered only in relation with her father, but Athena also represents the perfect realization of a male desire of giving birth: she was born from her father's head, without any kind of contamination with his guts, like a mother would. This brings us to associate her immediately to Wisdom. Plus, she is already an adult woman, this means she has no need to be raised, jumping that long phase of dependency of a child from their mother's body. She is a warrior woman and, as Sapegno says, her a-sexed nature corresponds to an absence of any kind of needs and frailties. She is rather an attribute of her father, and reproduces her father's characteristics at their ultimate level. By doing so, she always accomplishes her daughter's duties and her father's will. Plus, she does not even represent a threat, as she is a woman and Zeus cannot feel menaced by a daughter since the prophecy talked about a son. She is, basically, a mirror of her father, but as a

127 Sapegno, Maria Serena, Figlie del padre. Passione e autorità nela letteratura occidentale, Milano, Feltrinelli, 2018. 
woman she cannot aim to substitute him. ${ }^{128}$ These underlying forces that occur between Zeus and her daughter Athena are the same introduced by the motif of the daughter wearing male clothes to obey the father's will. As we will see, in most cases, to become a male in disguise is a necessity for escaping but at the same time it is a father's desire and a temporary situation. In fact, this desire is a comfort zone for the father, as he knows that his daughter will always be a daughter, and that her masculinity is only a temporary camouflage.

In the Aarne-Thompson index this kind of tales is classified with number 514, the Shift of Sex: 'The sister becomes a soldier in place of her brother. Marries the daughter of the king [K1837, K1322]. She is driven away and rescued by her companions. The change of sex in the ogress' house [D11]. Marriage with the princess [L161].'129 Inside this very archetype, it is quite conventional to find the court's physician motif, which usually sees the woman in male disguise being accepted at the king's court in order to become a counselor for the king. Let us not forget that the condition of disguise must be functional to the heteronormative system, thus there must happen something that brings the woman to reveal her identity and leave her male camouflage. For example, the court's physician archetype sees the male woman to reject the queen's sexual interest as in a heteronormative system a homoerotic interest cannot be considered as an acceptable alternative. This literary expedient is very common in medieval literature, and is also known as the narrative expedient of the Potiphar's wife. In the account of Joseph from the book of Genesis, while Joseph is working as a household slave for captain Potiphar, he receives the woman's attentions, and when he refuses her, she feels so humiliated by the refusal of a slave that she accuses Joseph of having attempted to seduce her. In the Genesis, Joseph is only a slave and his word is inferior to the one of Potiphar's wife, while in the Shift of Sex's motif there is still a chance for the woman to save herself from accusations, by revealing her identity and making the accusing woman appear as the negative example of womanhood to be punished with refusal from her husband or being sentenced to death. There is, so, a chance that is given to women adopting a male identity, to go back and take back their previous identity as a weapon to save themselves from danger. But, again, is there any limit to cross-dressing? ${ }^{130}$

\footnotetext{
${ }^{128}$ Sapegno, Maria Serena, Figlie del padre. Passione e autorità nela letteratura occidentale, quoted above, p. 21.

129 Aarne, Antti, The Types of the Folktale: A Classification and Bibliography. The Finnish Academy of Science and Letters, Helsinki, 1961, p. 181.

${ }^{130}$ Caraffi, Patrizia, Figure femminili del sapere, 2003, Roma, Carocci Editore.
} 


\subsection{Costanza and Costanzo and The Three Crowns}

The two folktales that I am going to introduce have many elements in common, and we can assume they belong to the same literary archetype. We must not forget that the Italian tradition has the merit of representing the first attempt to transcribe the oral tradition of folktales, tracing a fil rouge of transmissions and local re-adaptations that goes on from Boccaccio, to Straparola, to Basile, to Perrault, to the Grimm brothers. Giovanni Francesco Straparola's The Facetious Nights, ${ }^{131}$ first published in Venice in 1553, is the first European collection to include fourteen fairy tales among seventy-four novellas. It is likely that, as Straparola moved from Bergamo to Venice, he received the cosmopolitan influence of the city. Historians are not sure whether Giambattista Basile read him, but since several tales from Straparola are retold in Basile's Pentamerone, we can easily assume he did. From his novellas, we can notice his elevated education, his knowledge of Latin and various Italian dialects. His Nights were a great editorial success, republished twenty-five times from 1553 to 1613 and translated into French in 1560 and into German in 1791. I said he received the influence of the city as, being $16^{\text {th }}$ century's Venice one of the most relevant harbors for trades over Italy, Europe and the Oriental world, we can assume he would have contact with foreign cultures and oral traditions. ${ }^{132}$ However, there are clear proofs that his tales spread throughout Europe through print and by word of mouth. The Facetious Nights have a narrative structure that seems clearly inspired by Giovanni Boccaccio's Decameron, due to its structure of seventy-five novellas narrated during thirteen nights by the various characters belonging to the frame story.

In Costanza and Costanzo (Day Fourth, Novella 1) ${ }^{133}$ the cross-dressing is a personal choice of the protagonist, as she refuses her marriage with marquis Brunello after her father suggests this possibility. The embracement of the male identity represents for Costanza an opportunity to escape from the law of marriage, a strategy of resistance. She considers the man she is suggested to marry as not worthy of her lineage, and thus by marrying him she would "dirt" her kindred. Straparola already anticipates Costanza's tendency to become a virago when he describes Costanza's education, characterized by an interest for the arts but also for the training with the sword and other arms.

\footnotetext{
${ }^{131}$ Straparola, Giovanni Francesco, The Facetious Nights, trans. W.G.Waters 1894. Scanned original color illustrated editions.

132 Zipes, Jack, Why Fairy Tales Stick, Taylor \& Francis, 2006, p. 61.

${ }^{133}$ Straparola, Giovanni Francesco, The Facetious Nights, p. 167.
} 
The damsel, who was very prudent and conscious that she was sprung from high lineage, listened attentively to her father's words, and, with out wasting any time over the matter, answered him as follows: 'Sacred majesty, there is no need that I should spend many words in replying to your honorable proposal, but simply that I should speak as the question between us demands. And first I desire to testify to you my gratitude, the warmest I can express [...]. Next - speaking with all submission and reverence - I do not purpose to let myself fall to be low the race of my ancestors, who from all time have been famous and illustrious, nor do I wish to debase the crown you wear by taking for a husband one who is our inferior. You, my beloved father, have begotten four daughters, of whom you have married three in the most honorable fashion to three mighty kings, giving with them great store of gold and wide domains, but you wish to dispose of me, who have ever been obedient to you and observant of your precepts, in an ignoble alliance. Wherefore I tell you, to end my speech, that I will never take a husband unless I can be mated, like my three sisters, to a king of a rank that is my due.' ${ }^{134}$

We notice, then, that Costanza's refusal is not completely determined by a personal interest of not wanting to marry a marquis, but rather because of a respect for her father, that she would never dishonor by marrying someone inferior to him. The happy ending will be possible for Costanza only if she marries someone peer to her sisters' husbands, a king. Until then, Costanza decides to embrace independence, to become a man in disguise. This cross-dressing, if looked from this perspective, represents a sort of chastity vow for her, until the moment she meets a right husband.

In The three crowns by Giambattista Basile, as will be seen later, there is another simultaneity into embracing masculinity and the act of suspension of femininity.

Shortly after this, Costanza, shedding many tears the while, took leave of the king and queen, and, having mounted a gallant horse, set forth from Thebes alone, and determined to follow whatever road fortune might lay open to her feet. While she was thus journeying at hazard she deemed it wise to change her name, so in lieu of Costanza she called herself Costanzo, and donned a man's attire. ${ }^{135}$

When Costanza arrives after a journey to a city, the king who sees her from the window of the palace immediately feels attraction for her, even though she is now a young man.

The king, when he perceived the fair and graceful youth down below, had him called and brought into his presence, and as soon as Costanzo stood before him he demanded from what country he

\footnotetext{
${ }^{134}$ Straparola, Giovanni Francesco, The Facetious Nights, trans. W.G. Waters 1894, quoted above, p. 170.
} 135 Ibid. 
had come, and by what name he was called. The youth, with a smiling face, gave answer that he had journeyed from Thebes, driven thence by envious and deceitful fortune, and that Costanzo was his name. He declared, moreover, that he desired greatly to attach himself to the service of some gentleman of worth, pledging himself to serve any such lord with all the faith and affection that good service merited. The king, who mean time was mightily pleased with the appearance of the youth, said to him: 'Seeing that you bear the name of this my city, it is my pleasure that you tarry here in my court with no other duty laid upon you than to attend to my per son.' 136

The overlapping of desire is very common in this kind of archetype, and no doubt William Shakespeare took inspiration from this motif of the court's physician for his Twelfth Night. Just as Olivia and the Duke Orsino fall in love with Cesario/Viola, here both the king and the queen feel attraction for Costanzo. Like in the case of Olivia's attraction for Viola, here the desire of the queen is rejected from the beginning by Costanzo, and the interest of the queen will quickly become hatred against Costanzo (the implementation of the Potiphar's wife scheme, as we have seen before).

Wherefore the queen, being thus consumed with passion for Costanzo, yearned for nothing else than that she might some day find occasion to foregather with him alone. And before long it came to pass that chance gave her the opportunity of conversing with him, so she straightway inquired of him whether it would be agreeable to him to enter into her service, making it known to him likewise that by serving her he would gain, over and above the guerdon which she would give him, the approbation or even the reverence and respect of all the court. ${ }^{137}$

Each time that in this kind of archetype a lesbian desire is represented, it is always minimized as an infatuation of the woman for the male in disguise. In Twelfth Night, when Olivia reveals her love for Viola, it is Viola herself who explains to the Countess that she is mistaken, as there is no chance for $16^{\text {th }}$ century's Elizabethan society to accept a female homoerotic interest for another woman. Thus, the homoerotic desire is justified as a misunderstanding due to the male crossdressing for the woman and to the gentle appearance of the disguised character for the man. ${ }^{138}$ Costanzo, then, reveals to be Costanza, and makes the evil queen be punished by the king, who sentences her to death, by making possible the union of Costanza with the king.

\footnotetext{
136 Ibid., p. 171.

137 lbid., p. 172.

${ }^{138}$ Charles, Casey, Gender Trouble in "Twelfth Night". Theatre Journal. Vol. 49, No. 2 (May, 1997), pp. 121 141.
} 
In The Three Crowns ${ }^{139}$ by Giambattista Basile (Sixth Entertainment of the Fourth Day) there is the breaking of an oath from the female protagonist as expedient for her renunciation to her femininity. The protagonist, Marchetta, is accepted as a servant in an ogress's house, and the ogress promises her a good marriage only if she respects the prohibition of entering the secret room in the house. As in the case of the Bluebeard's archetype, here curiosity wins again.

Seeing her, the ogress answered, 'I could kick myself; you were one up on me! You did a master's job, and you saved yourself a nice bake inside this belly. But since you've been capable of doing so much and have given me pleasure, I intend to treat you even better than a daughter. And so here are the keys to my chambers, and may you be mistress and ruler of them. Only one thing will I withhold from you: you must not under any circumstance open the last room, which this key opens, for it would be like mustard under my nose. Take care to serve me well, and-lucky you!-I promise, on my three crowns, that I will arrange a very rich marriage for you.' Marchetta kissed her hand in thanks for so much grace and promised to serve her better than a slave. ${ }^{140}$

Having lost the chance for a good marriage, the only possibility that remains for Marchetta is to embrace masculinity as an alternative to find fortune. She is no more a woman, yet she has the chance to interact with the homosocial sphere. Nevertheless, acting like a man does not mean to be a man, but rather a mid-man, since her desires cannot be accomplished. She cannot express her interest for the king who appears attracted by her, nor accept the advances of the queen. However, even though the ogress is disappointed by Marchetta's disobedience, she tells her she will be her protection, by giving her a magic ring that Marchetta will always have to wear and the ogress will come to help her if she is in danger. Suddenly Marchetta finds a job as a court counselor for the king, and as in the case of Costanza, here again both the king and queen feel attraction for her/him: 'The king was pleased with Marchetta's quickness and good manners and took her on as a page. He brought her to his palace, and as soon as the queen saw her she felt all her longings blown up by a bomb of graces. ${ }^{141}$ Again, in order to make possible the accomplishment of a successful conclusion and a return to the original femininity, the evil queen who cannot accept Marchetta's refusal and that represents the Dworkinian "active woman" has to be punished with death so that the marriage between Marchetta and the king can be possible.

\footnotetext{
139 Basile, Giambattista, Lo cunto de li cunti, a cura di Michele Rak, VI ed., Milano, Garzanti, 2007, quoted above, p. 337.

140 lbid., p. 341.

141 Ibid., p. 342.
} 


\title{
3.3 The body of evidence: cross-dressing and battlefields
}

An interesting example of cross-dressing and resistance in contemporary literature is given by Maxine Hong Kingston's autobiography The Woman Warrior. Memoirs of a girlhood among ghosts, ${ }^{142}$ published in 1976, which explores the connection between empowerment, self-discovery through disguise and the limits of desire. It is interesting to look at the development of the novel if compared to the tales we have seen or to the tale of Fantaghiro the Beautiful, collected by Italo Calvino in his Italian Folktales. The title of Kingston's novel derives from the Chinese mythology of Fa Mu Lan, a virago who fought for the Chinese Emperor to save her father's honor disguised as a man, and this legendary character will become a leitmotif in the book, as Mu Lan represents the idea of femininity that Maxine aims to, which collides with her Chinese education.

The first chapter is called 'No Name Woman;' it is, in fact, the untold story of dishonor and oblivion of her suicidal aunt that brings Maxine to start her narration.

\begin{abstract}
"You must not tell anyone," my mother said, "what I am about to tell you. In China your father had a sister who killed herself. She jumped into the family well. We say that your father has all brothers because it is as if she had never been born. [...] I remember looking at your aunt one day when she and I were dressing; I had not noticed before that she had such a protruding melon of a stomach. But I did not think 'She's pregnant,' until she began to look like other pregnant women, her shirt pulling and the white tops of her black pants showing. She could not have been pregnant, you see, because her husband had been gone for years. No one said anything. We did not discuss it. In early summer she was ready to have the child, long after the time when it could have been possible."143
\end{abstract}

It is quite explicative how the narration becomes, for Maxine, an instrument of atonement for that forgotten woman without name belonging to her family, who only survives through her mother's memory and narrating voice. Maxine tries to reach that blurred No Name Woman by representing her story. The act of narration from Maxine's mother's voice brings that woman to existence, while her family itself had decided to remove her story as it happens with traumas: 'We say that your father has all brothers because it is as if she had never been born.' ${ }^{144}$ The reason why Brave Orchid, Maxine's mother, tells her the story of her aunt is to avoid that her daughter could do the same mistakes her aunt did.

\footnotetext{
142 Kingston, Maxine Hong, The Woman Warrior: Memoirs of a Girlhood Among Ghosts, Random House, 1989, New York.

143 Ibid., p. 3.

144 lbid.
} 
Thus, we can consider the story of No Name Woman as a black fairy tale told to Maxine to understand what happens to a fallen woman who does not respect the role given to her by society and family values. It is not by chance that this moment anticipates Maxine's menstruation, as if her process of growth is simultaneous to the acceptance of her role as a subdued woman. 'Don't let your father know that I told you. He denies her. Now that you have started to menstruate, what happened to her could happen to you. Don't humiliate us. You wouldn't like to be forgotten as if you had never been born. The villagers are watchful. ${ }^{145}$

Now, more than the story of abjection and neglecting, what I think is the most interesting aspect of the story of No Name Woman is what Maxine does with her imagination. She creates a story for this ghost woman, she makes her live through invention, and the silence itself becomes for her a strategy of resistance to explore. Hong Kingston evokes the silence, and gives her aunt a mythology of possibilities. She wonders what reasons could have induced No Name to go with another man. She refuses the idea of her aunt as a wild woman with no moral values traced by her mother and her family, and she thinks about her as a sort of heroine, who decided for herself, and was brought to suicide because of Chinese social and moral values. In the last section of the first chapter, Maxine imagines the last moments of her aunt's life, and she assumes the reasons why the woman, after having given birth to her child in a pigsty, decided to kill herself together with her baby. The reason is that her aunt probably did not want a life of privations and disgrace for her daughter, and Maxine imagines that the baby was a girl, too, as if subordination were a stigma inherited with the female sex, and only the act of self-killing could be the key for escaping submission.

Full of milk, the little ghost slept. When it awoke, she hardened her breasts against the milk that crying loosens. Toward the morning she picked up the baby and walked to the well. Carrying the baby to the well shows loving. Otherwise abandon it. Turn its face into the mud. Mothers who love their children take them along. It was probably a girl; there is some hope of forgiveness for boys. ${ }^{146}$

The chapter closes with the image of Maxine's aunt as a ghost that persecutes her.

My aunt haunts me -her ghost drawn to me because now, after fifty years of neglect, I alone devote pages of paper to her, though not origamied into houses and clothes. I do not think she always

\footnotetext{
145 lbid., p. 5.

146 lbid., p. 19.
} 
means me well. I am telling on her, and she was a spite suicide, drowning herself in the drinking water. The Chinese are always very frightened on the drowned one, whose weeping ghost, wet hair hanging and skin bloated, waits silently by the water to pull down a substitute. ${ }^{147}$

This passage has a symbolic relevance. It links to the title of Kingston's autobiography, 'memoirs of a girlhood among ghosts'. As Kingston explains in her book, Chinese people use the term "Ho Chi Kuei" to refer both to ghosts and to Chinese immigrants. An almost correct translation in English for "Ho Chi Kuei" could be "wandering ghost", "homeless spirit", "rootless soul", that is exactly what Maxine is, a shadow in the middle of two worlds and cultures, she is too Chinese to become American, and too American to be considered as a Chinese. She is, to sum up, a hybrid creature.

Another theme deals with her education and achievements during her childhood, explained in chapter 2, called "White Tigers". Here, we see in action the process of absorbing her mother's stories, and how these stories are constantly reminding Maxine to not be too American and be faithful to her family's spirit. An explicatory moment of Maxine's difficulties to understand how to behave to honor her family is when she comes back home and tells her mother she got an A, and suddenly her mother tells her the story of a girl who saved her village, as if she wants to scale back her daughter's skills. The author, then, in her own way, re-elaborates these stories told to her, she interiorizes them as life-lessons, although in certain cases she does not understand their sense in depth. The moral and ethics of those stories struggle to fit in Maxine's American life.

My American life has been such a disappointment. "I got straight in A's, Mama." "Let me tell you a true story about a girl who saved her village." I could not figure out what was my village. And it was important that I do something big and fine, or else my parents would sell me when we made our way back to China. In China there were solutions for what to do with little girls who ate up food and threw tantrums. You can't eat straight A's." 148

Maxine herself, after her mother tells her the story of the little savior, feels that her A is not a great thing to achieve. However, here comes the point that is functional to our discourse on cross-dressing as resistance.

The first section of the second chapter represents Hong Kingston's fantasy of living the life of Fa Mu Lan, the legendary Chinese heroine who disguised as a man to save the

\footnotetext{
147 Ibid., p. 20.

148 lbid., p. 48.
} 
honor of her family and guided an army for the Chinese Empire. The story of Fa Mu Lan is narrated in first person: Maxine identifies herself with the legendary warrior. She imagines herself walking on a mountain where she starts the training to become a warrior, her parents tattoo their name and home address on her back before she leaves for the war, so that her body can be brought home if she dies on the battlefield. While her life goes on, Maxine seems not to care about the fact that her parents already have combined a marriage with a 12-year-old boy; she lives in an alienated world of tales and action.

My first opponent turned out to be a giant, so much bigger than the toy general I used to peep at. During the charge, I singled out the leader, who grew as he ran toward me [...] First I cut off his leg with one sword swipe, as Chen Luan-feng had chopped the leg off the thunder god. When the giant stumped toward me, I cut off his head. Instantly he reverted to his true self, a snake, and slithered away hissing. ${ }^{149}$

This action of sublimation of her true self with Mu Lan's identity can represent her childhood attempt to look for a connection with her Chinese identity, that she feels so distant from her American education. However, I also see in Maxine's endeavor to live $\mathrm{Mu}$ Lan's life a way to escape from a world made of inherited traditions, combined marriages and social impositions. The crossdressing as a man, according to the legend, is the only chance for Fa Mu Lan to be an active character, albeit she must refuse her female identity, even if temporally. She looks for a compromise, she must save her father's honor who was no more able to fight for the Emperor, and she chooses to become her father's son. $\mathrm{Mu}$ Lan disappears in the image of a disguised masculinity that legitimizes her as a warrior. Maxine, at the same time, disappears in the simulacrum of a woman warrior in man's camouflage. What I think is the most interesting aspect of Hong Kingston's work is her attempt to give voice to Chinese women of previous generations. Her women's stories, including her own, are nothing but an attempt of revenge of that very female world against a millenary patriarchal system, that in China has exercised its deathly and violent power of oppression. It is the same system that celebrates the sons and denigrates the daughters; the same system that the author-child does not understand and that she categorically refuses. 'Oh, come on now. Everyone takes the girls when he can. The families are glad to be rid of them. 'Girls are maggots in the rice.' 'It is more profitable to raise geese than

149 lbid., p. 40. 
daughters. ${ }^{150}$ We can also read in this way the identification of Maxine with Mu Lan as a process of empowerment that materializes only when she dresses up as a male warrior. Nevertheless, that warrior is a subversion of the patriarchal scheme. It is the chance, for a daughter, to prove her skills in a male world that pushes daughters to the borders.

Speaking about the subject of the woman warrior, what I found related to my research about strategies of female resistance were two aspects; one is the way Maxine explores her Chinese background to find female examples of agency to evoke a counterhistory of forgotten women. The other aspect is related to the connection between the female masculinity represented by Maxine/Fa Mu Lan and the cross-dressing of the characters I found in the folktales that we encounter in Giambattista Basile's and Italo Calvino's collections.

In addition, I will show you two folktales related to his topic where the female protagonist must wear as male warrior in order to preserve either the kingdom or the father's honor. These two tales are La foresta di aglio (The Garlic Patch), from Basile's Lo Cunto de li Cunti and Fantaghirò, persona bella (named Fantaghirò the Beautiful in the English translation by George Martin). ${ }^{151}$ Even though Belluccia, protagonist of The Garlic Patch, belongs to the Neapolitan tradition while Fantaghirò to the Tuscan one, there are many elements in common in the structure of these two folktales, which are present also in the German tradition. ${ }^{152}$ In each one of them, for example, there are three proofs that the women dressed like men must accomplish in order to confirm to suspicious observers that they truly are men. In The Garlic Patch a man, Ambruoso di Barra, father of seven daughters, is asked from another nobleman, his friend, to send one of his sons to his house to be a company for his son, Narduccio, who is sick. Ambruoso feels ashamed because he only has daughters and, in order to preserve his honor, he asks her daughters to wear as men in order to satisfy his friend's request: 'Ambruoso went to visit him, and was asked by Biasillo how many children he had. Ashamed to tell him how he had grafted so many little farts, he said, 'I have four sons and three daughters.' 'If that's the case,' replied Biasillo, 'send one of those sons of yours to keep my son company, and you'll be doing me a big favor.' ${ }^{153}$ As we can see from Ambruoso's words, birthing only daughters

\footnotetext{
150 lbid., p. 46.

${ }^{151}$ Calvino, Italo, Italian Folktales, A Harvest Book. A Helen and Kurt Wolff Book, Harcourt, Inc. San Diego, New York, London, 1980.

152 Ibid., p. 952.

${ }^{153}$ Basile, Giambattista, Lo cunto de li cunti, a cura di Michele Rak, VI ed., Milano, Garzanti, 2007, quoted above, p. 336
} 
not only was a shame. The narrator compares the women to 'little farts,' underlining their lack of reputation because of their sex. Belluccia, who is Ambruoso's minor daughter, is the only one of the seven sisters to put her love for her father before of her sense of honor, so that she accepts his will.

When the last little nest shitter, Belluccia, saw that at each of her sisters' answers her father heaved a sigh, she answered, 'If disguising myself as a man is not enough to serve you, l'll become an animal, I'll shrink down to nothing to make you happy!' 'Oh, bless you!' said Ambruoso. You're giving me your life in exchange for the blood that I gave you! Now, come on, let's waste no time; we need to strike while the iron is hot!154

Consequently, Belluccia is brought to Biasillo's house disguised as a boy to entertain Narduccio with her presence, and the young man is suddenly struck by Belluccia's beauty, even when disguised, that he immediately thinks that Belluccia must be a lady. Hence, with the help of his mother's wisdom, he prepares proofs for Belluccia to unmask her identity, but she always is able to pass them. These proofs are supposed to verify that if she were a lady, she could never be able to win. In the first one, she is asked to tame the wildest horse of the stable, because, according to Narduccio's mother, 'if she's a woman you'll see her spin the thin thread of fear, since women don't have much courage, and then we'll check which way those weights fall.' ${ }^{155}$ During the second proof, Belluccia has a musket brought to her and she is asked to load and shoot it, and she wins again. Narduccio's mother tries to convince him that the proofs show that Belluccia is a boy, because 'you must realize that a woman could never do that!'156

The discovery of Belluccia's female sex is due to an accident, as Narduccio goes to Ambruoso's house, where Belluccia lives, with no advice, and even though Belluccia rapidly wears her man's clothes, she forgets her earrings on, and that is the proof for Narduccio that he was right. Here, more than anywhere else is clear how gender is validated through the performance of it, since only by passing the tests can Belluccia confirm her masculinity to her judges. Her skills in acting like a male save her, and only an error of distraction, her earrings, cheat on her performance.

\footnotetext{
154 lbid., p. 337.

155 Ibid., p. 251.

156 lbid., p. 338.
} 
In Fantaghirò the Beautiful, from Italo Calvino's Italian Folktales, the girl must become a man because the king, her father, is too old to fight a war against the king of the neighbor realm. Since the king has no male sons to send at war but only three daughters, Fantaghirò seems to be the only one that is able to perform as a man. At the beginning of the tale, all the king's daughters want to fight as men for their father, but they must pass a test before.

"If you'll allow me," said the oldest girl, "I'll be your general myself. I command your household. Do you think I couldn't command your soldiers?" "Don't be silly! That's no task for a woman!" said the king. "Do let me try," begged Assuntina. "Very well. We shall try," said the king. "But understand that if, along the way, you get to talking about women's work, you march straight back home." Assuntina agreed to that condition, and the king ordered his trusted squire, Tonino, to mount his horse and ride with the princess to war, but to bring her straight home to the palace the first time she mentioned women's work. The princess, dressed regally in silk, mounted her horse sidesaddle and rode with the squire off to war. The army marched behind them. They had already gone a good long way when they came to a cane field and started through it. The princess exclaimed, "What magnificent canes! If we had them at home, we could make any number of distaffs for our spinning!" "Halt, princess!" cried Tonino. "I am under orders to take you back to the palace. You brought up

women's work." They wheeled their horses around and the whole army about-faced and followed them back. ${ }^{157}$

After the second sister fails, Fantaghirò is the only one who does not talk about women's work and here again her gender performance gives her the chance to be recognized as a man.

"Is there any harm in letting me try, Papa? I promise not to disgrace you. Let me try." It was agreed that Fanta-Ghiro would go to war. She dressed as a warrior, with helmet, armor, sword, and two pistols, and galloped off with Tonino at her side and the army behind them. They passed the cane field without comment and soon reached the border. ${ }^{158}$

Even in Calvino's tale, as in Basile's The Garlic Patch, the rival king falls in love with Fantaghirò at first sight, and here, too, he tries to challenge her real masculinity with three proofs, with the help of his wise mother, the Queen.

${ }^{157}$ Calvino, Italo, Italian Folktales, quoted above, pp. 249-250.

158 Ibid., p. 250. 
Realizing that her son was head over hills in love, the queen said, "Invite him to dinner. If the general holds the bread against his chest when he cuts it, then the general is a girl. But if he holds it in the air and cuts it, he is a man for sure and you have fallen in love for nothing." At dinner, the results of this test were no better. Fanta-Ghiro cut her bread like a man, discussing politics. ${ }^{159}$

In both the stories of The Garlic Patch and Fantaghirò, during the proofs, there is a symbol (e.g. the earrings), a gesture (e.g. cutting the bread in a man's manner), an action (e.g. taming a horse) that give a public identification of the maidens as 'real men'. Each one of these details is connected with a performative process that dichotomizes the masculine and the feminine being. But, while in Fantaghirò her man's disguise can perhaps represent an act of agency as a member of the royal family, in The Garlic Patch Belluccia is dressing like a boy only to satisfy her father's desires. Her sex and her will remain subordinated to the archetypical idea of respect for the image of the father. She is not an active character, except for the moments in which she must confirm her gender. Fantaghirò, on the other hand, must satisfy in any case her father's desires to bring peace between two realms in war, and she makes the king fall in love with her, as well. However, both the folktale and the historical context are two worlds colonized by a heteronormative and male-controlled system, where the cross-dressing can only represent a temporary ambiguity of identity, not an eternal condition. The woman that is acting outside the norm must be re-absorbed by that same norm, there is no chance for her to abandon the previous identity and follow the Law of Desire; there is a duty to respect, be a woman functional to a capitalist concept of society.

The only action given to these women is to decide how to use the disguise, and when to reveal their true identity. When the Italian historian and writer Maria Rosa Cutrufelli wrote in her book, L'Unità d'Italia: guerra contadina e nascita del sottosviluppo del Sud, about the clans of Italian brigands in Italy during the late-eighteenth century, she mentioned as well the experience of women who joined the bandits and used to wear like men. When she describes the photographs of female bandits of those times, she says:

"...they represented an explicit insult to the moral of that time; they usually used to wear the most practical male outfit, with their legs opened (in the middle of 1800's!), carrying guns and other weapons with the greatest dexterity." 160

\footnotetext{
159 lbid., p. 251.

160 Cutrufelli, Maria Rosa, L'unità d'Italia: guerra contadina e nascita del sottosviluppo del Sud, Bertani, Verona, 1974. My translation.
} 
The Italian female brigands were outsiders, they had refused the role assigned to them from society and they had joined the brigands to live the life they wanted, where they were considered as peers. But another interesting aspect from Cutrufelli, which brings me to my discourse on folktales, is the act of manipulation of their sexuality. Usually, when the brigandas were caught by the Italian army and were menaced of being shot if they did not surrender, they used to show their breasts or their belly, as if they said: we are women, don't shoot us! Many of them were spared their lives just because of their revindication of femininity. This confirms that yes, they used to live at the borders of 19th century society, where they were not considered as conventional or acceptable ladies, but at the same time their body became again the instrument of reconnection with a female identity that could give them the chance to save their lives. They used their identitarian ambiguity for their own personal gain. They re-entered in a patriarchal scheme of social acceptability because of their naked bodies that said: we are women. Their naked bodies meant, for the soldiers who could shoot them, that those men in disguise were ladies, that they could be wives, mothers and daughters, and those women used their nudity as a strategy of empowerment, the only one they could exercise at that time, by avoiding death by shooting as the other male bandits. ${ }^{161}$

Cutrufelli, who is an historian but also a novel writer, wrote, in 1990, her first novel, called La briganta, based on her previous historical research. It is a first-person memoir of a woman who became a brigand in 1863. Margherita, the main character, joined the band and became an outlaw, and the novel shows how the story of a woman brigand might represent not only the ambiguity of the historical identity during the Italian unification, but also the struggle for a woman to find a meaning to her female self and a place in History. In the two folktales I analyzed, both Belluccia and Fantaghiro are exposed to the risk of being seen naked. Both Narduccio from The Garlic Patch and the king fallen in love from Fantaghiro suggest them to have a bath in the pond; so, the girls invent excuses not to join the bath, since they could not hide the truth in their nudity in that way, they know that they would fail the proof if they show their naked body. Only the body matters, as the heterosexual confrontation of genitality is the only one accepted by the dominating

161 Michelacci, Lara, Ricostruire l'identità, reinventare il passato: La briganta di Maria Rosa Cutrufelli. Poetiche. Rivista di letteratura, pp. 217-234 
moral; ${ }^{162}$ thus, by showing her naked body, the cross-dressed woman would reveal herself as an available and conventional object of male desire. And here, again, they both exceed the gender system in order to accomplish their mission, but just as the female bandits they eventually re-enter patriarchal roles, by marrying the men who tested their sexual identity and making the happy ending possible. But, again, isn't marriage itself an expression of male control? Girls pass from an owner, their father-king, to another, their husband, (see Chapter Two) who had observed them during the whole story, and finally obtain their prize: those men in disguise. This is the reason why the male camouflage cannot completely represent a path for freedom for the female characters of these tales. Even in the case of Kingston's Mu Lan, the legendary heroine goes to war because she must preserve her father's honor; it is Maxine, with her own narration, who gives to Mu Lan a different, picaresque and independent mythology, that is divergent from the traditional one.

\subsection{Homoerotic desire and original hermaphrodism}

As I have already shown in the previous chapters, the universe of folktale is based on conformist roles and models that should be an example of behavior for the community. In such a context, the reason why a homoerotic desire would not be a contemplable choice whatsoever is easily comprehensible. Fantaghirò, Belluccia, Marchetta, Viola, Costanza: they are all drags, and they are all performing a part in their play, and as the drag that was theorized by Judith Butler in Gender Trouble, they are all breaking the notion of Norm. The desire shown by the king and the queen, who react to the presence of the male in disguise, goes beyond the biological sex of the protagonist. According to what is expressed by Mario Mieli in his provocative 1977's essay Towards a Communist Homosexuality (Elementi di critica omosessuale), which is still a milestone in the field of gender studies, there is an 'original polymorphism' that is present in each individual and that develops since childhood. Society considers this polymorphism as a perverse phase of infantile sexual development that should be abandoned during the individual's access to adulthood. Bisexuality was considered by psychoanalysis as a behavioral indicator of the fetal phase in which, according to some scientific and common beliefs, there is the coexistence between male and feminine genitalia. This is the psychoanalytic justification to

162 Mieli, Mario, Elementi di critica omosessuale, Milano, Feltrinelli, 2018, p. 17. 
human inner bisexuality. ${ }^{163}$ According to Gilbert Dreyfus, 'although genetic sex is determined by the composition of the fertilizing spermatozoon, so that the father alone is responsible for the genetic sex of his offspring, the embryo undergoes in its early development a phase of apparently undifferentiated sexuality. ${ }^{\prime 164}$ In these folktales, we can notice how the king/young man (it depends on the version of the tale) feels immediately an attraction for the man in disguise, who is identifying himself as a man, and this is nothing but homoerotic desire from the king for the person he has in front. Nevertheless, there is only a way to eliminate the impasse of homosexuality: removal. Mieli believes that 'the hatred generated towards us within heterosexual society is caused by the repression of the homoerotic component of desire in those individuals who are apparently heterosexual. The general repression of homosexuality, in other words, determines the rejection by society of the manifest expressions of the gay desire.'165 Only through a process of suppression and removal of the homoerotic desire can the heteronormative union be considered as such. Otherwise, the king's desire is associated with foolishness, as we can see from the judgement of the king's mother, who thinks her son is getting mad as he has fallen in love with what seems to be a man (see section 3.3).

But what about the repression of desire for the male in disguise, then? How can it be accomplished in such a heteronormative space? I will quote Mieli's considerations on the transsexual desire that, even though related to the non-binary condition of the transsexual, can make us figure out the self-perception of the disguised woman, who feels a "monster", a hybrid that cannot fix into the binary society:

At the present time, these manifest transsexuals are still subject to the contradiction between the sexes and the repression of Eros, which is the repression of the universal trans-sexual (or polymorphous and hermaphrodite) disposition common to all human individuals. Persecuted by a society that cannot accept any confusion between the sexes, they frequently tend to reduce their effective trans-sexuality to an apparent monosexuality, seeking to identify with the opposite 'normal' gender to their genital definition. ${ }^{166}$

According to Casey Charles and his essay Gender Trouble in Twelfth Night, there was also a social reason for the choice of character with a non-binary sexual identity, and the reason was to create a debate. In the Shakespearian play Twelfth Night, when Viola,

\footnotetext{
163 Mieli, Mario, Elementi di critica omosessuale, quoted above, p. 19.

164 lbid.

165 lbid., p. 22.

166 lbid., p. 27.
} 
dressed as Cesario, reflects on her condition, she defines herself as a 'poor monster,' and later she will blame transvestism itself as 'a wickedness, / Wherein the pregnant enemy does much' (2.2.26-27). As Charles says,

\begin{abstract}
Viola's androgynous performance as a woman playing a man, like the position of the young men playing women's parts on the Elizabethan stage in general, upsets the restriction of erotic attraction to heterosexual binarism in part because that dualism is collapsed in a single subject. As Viola is a man, her "state is desperate for her master's love," but as Viola is a woman, Olivia's sighs for her must prove "thriftless," under the social condemnation of same-sex love (2.3.35-38). She not only upsets essentialist constructs of gender hierarchy by successfully performing the part of a man as a woman, but in her hermaphroditic capacity as man and woman, I will argue, she also collapses the polarities upon which heterosexuality is based by becoming an object of desire whose ambiguity renders the distinction between homo- and hetero-erotic attraction difficult to decipher. The theatrical convention of cross-dressing and the androgyny it comes to symbolize thus challenge the regulatory parameters of erotic attraction through the vehicle of performance, a performance that shows gender to be a part playable by any sex. ${ }^{167}$
\end{abstract}

Is there a solution thus, a way of escape for homoerotic desire in folktales? There is not, of course. The only way to achieve happiness is by re-entering the Norm. Once the maiden has experience a camouflaged masculinity, she must now be a good girl and return to her previous condition. What should be possible as a strategy is what Mario Mieli defines as the necessity of a return to an original and deep hermaphrodism, or original bisexuality. 'Trans-sexuality' he says, 'seems to me the best word for expressing, at one and the same time, both the plurality of the erotic tendencies and the original and deep hermaphrodism of every individual.' ${ }^{168}$

\footnotetext{
${ }^{167}$ Charles, Casey, Gender Trouble in "Twelfth Night", quoted above, pp. 127-128.

168 Mieli, Mario, Elementi di critica omosessuale, quoted above, p. 26,
} 


\section{Final considerations}

In the first chapter I tried to find the connection between the vice of curiosity and female subjectivity by exploring each tale connected with the Bluebeard archetype that represents, in this way, a different declination of curiosity. The heroine from the Perraultian 'La Barbe Bleue' is the one who inspired Angela Carter for The Bloody Chamber. Her passivity from the original tale is retaken by Carter to become a starting point from where she moves in order to make the protagonist realize that she is, indeed, a subject, and of course transgression of the rules is part of this process. If Anton Chekhov said that when an author puts a gun hanging on the wall in a story that gun must shot sooner or later, ${ }^{169}$ at the same time the secret of the bloody chamber is there to be unveiled. Additionally, the female protagonist is there to break the oath with her husband and become a subject, she saves herself from violence by acquiring knowledge of her husband's deadly habits. We gradually become active subjects understanding the reasons of her disobedience.

In chapter two, I focused on a female-female interaction, and how this depiction is distorted and influenced by the male-controlled necessity of creating a mystified thesis and antithesis of women in popular culture. As we have seen, the central issue of the tension between women is the man to whom they must be devoted. I have also focused on the persecuted maiden archetype in folktale, and while referring mostly to Rubin and LeviStrauss's essays, I have shown that the representation of marriage and of the fatherdaughter relationship are both instruments of power in the hands of men.

In the third and last chapter, desire and repression of desire, in connection with the versatility of the female body and the blurring of identity in folktales has been the main topic. I tried to stress the heteronormative system of values that affects the behaviour of the characters, who end up acting to revalidate the Norm by repulsing abnormality.

When I started thinking about this essay, I was immediately filled with excitement and enthusiasm into revisiting the universe of the folktale using a feminist perspective to deconstruct the pillars of it. In my mind, the utopian project of this study was to give back voice and subjectivity to the subaltern being. The postmodern tradition, mainly represented by Angela Carter's work and her collection The Bloody Chamber, represented the perfect ally in this battlefield in the clash with the past.

169 Selvidge, Lisa, Writing Fiction Workbook, Lulu Enterprises, UK: "If you say in the first chapter that there is a rifle hanging on the wall, in the second or third chapter it absolutely must go off. If it's not going to be fired, it shouldn't be hanging there," p. 78. 
I decided to give this project the title How to escape from the bloody chamber, not only to make a riddle with the title of Carter's tales, but also because I liked the idea of creating a little compendium of selected examples that could give an alternative interpretation to the narrative choice of the traditional fairy tale. Thus, the desire of curiosity for the protagonist of La Barbe Bleue becomes an act of self-liberation, of unaware resistance against gender violence, and while Charles Perrault looked at "female curiosity" as a trace of the original sin and a risk for women, whose role should be guided by obedience and respect for the patriarchal law, a feminist reading of the story would look at that action as a demonstration of self-preservation. Escaping from the bloody chamber means to have broken an oath, it means to have seen inside the secret of the bloody chamber and have become a non-conventional subject, not pledged to conservative roles, not passive. In curiosity and disobedience, there is freedom. I wanted to present examples of resistance and rebellion, but while getting deeper in my research I found out that, in many cases, this resistance is partial, and always functional to the patriarchal project of the narration: a girl who escapes from her family because she experiences violence cannot escape all her life, she is destined to pass from a man to another, there is no chance for her to live on her own without having a male counterpart to "complete" her. Furthermore, as we have seen in the third chapter on cross-dressing, since folktales produce models of behaviour, they limit the chances for desire to increase spontaneously, as that very desire must always be guided by a moral, by ethical and biological reasons that still today justify a determinist and heterosexual conception of relationships, as Mario Mieli's essay perfectly explains.

The production of common beliefs on human actions and behaviours has its origin in the collective imagery produced by legends, traditions and folktales, and as I have attempted to explain, the conflict between women has been useful to the male tradition as a tool to look at women as a weaker community. I have discovered, now more than ever, that the universe of folktale is brutal, extreme, irrational and merciless. It is a universe in which it is normal that a mother tells her daughters to mutilate their feet so that they can wear the crystal shoe belonging to Cinderella, it is a world where in order to make possible the marriage between the king and his new crush, the king must sentence to death his previous wife. How can we be sure that this fate will not be re-enacted with the second wife? It is a universe where social interaction and male and female roles produce stereotyped visions of the world, which colonize the way we are used to perceive reality. 
After all, folktales are considered still today as a child's first approach with the world of imagination and literature, even though our social and ethical values change and keep on changing. For this reason, I hope that my essay could tell a different version of the story, so that tradition may be looked with a disenchanted gaze.

In conclusion, speaking about those partial strategies of resistance, which do not make a woman completely free, I think they can represent a starting point for the elaboration of new roles, new models, so that the runaway maiden may not be recaptured by the wheels of oppression.

What I have tried to do here represents a partial attempt of investigation of the tradition of folktales. I found it surprising that the Italian tradition of folktales and the European one in general still need a radical comparative analysis of gender roles and the limits of subjectivity. Folktales have a non-specified origin, and in a certain way, they represent an archetypical code of conduct approved and reproduced by the imagery of society, until nowadays. The modern, or I would say, postmodern crisis of conservative models, today, is due to the deconstruction and change of beliefs that should stimulate us 'to see [tradition] with fresh eyes'. ${ }^{170}$ Therefore, an approach to the structure of tradition, together with the support of cultural studies, could help to eviscerate this discourse, and represent the opening for a potential project of research.

\footnotetext{
170 Rich, Adrienne, When We Dead Awaken: Writing as Revision, from Rich, Adrienne (1995). On Lies, Secret, and Silence. W. W. Norton \& Company. pp. 33-108 "Re-vision-the act of looking back, of seeing with fresh eyes, of entering an old text from a new critical direction-is for us more than a chapter in cultural history: it is an act of survival. Until we can understand the assumptions in which we are drenched we cannot know ourselves. And this drive to self-knowledge, for woman, is more than a search for identity: it is part of her refusal of the self-destructiveness of male-dominated society. A radical critique of literature, feminist in its impulse, would take the work first of all as a clue to how we live, how we have been living, how we have been led to imagine ourselves, how our language has trapped as well as liberated us; and how we can begin to see-and therefore live-afresh."
} 


\section{Bibliographical sources}

- Aarne, Antti, The Types of the Folktale: A Classification and Bibliography. The Finnish Academy of Science and Letters, Helsinki, 1961

- Atwood, Margaret, Bluebeard's Egg, Toronto, McClelland \& Stewart, 1986

- Bacchilega, Cristina, An Introduction to the "Innocent Persecuted Heroine" Fairy Tale, Western Folklore, Vol. 52, No. 1, Perspectives on the Innocent Persecuted Heroine in Fairy Tales (Jan., 1993), pp. 1-12

- Bacchilega, Cristina, and Roemer, Danielle M., Angela Carter and the Fairy Tale, Wayne State University Press, 1998

- Bacchilega, Cristina, Postmodern Fairy Tales: Gender and narrative Strategies, Philadelphia, University of Pennsylvania Press, 1997

- Baccolini, Raffaella; Fortunati, Vita; Fabi, M. Giulia; Monticelli, Rita, a cura di, Critiche femministe e teorie letterarie, CLUEB, Bologna, 1997

- Basile, Giambattista, Lo cunto de li cunti, a cura di Michele Rak, VI ed., Milano, Garzanti, 2007

- Benvenuti, Anna, Santi e notai: Ser Baldovino Baldovini e il volgarizzamento della vita di Santa Verdiana da Castelfiorentino, da Studi per Franco Cardini, a cura di Marina Montesano, Firenze, Sismel, Edizioni del Galluzzo, 2010

- Bettelheim, Bruno, The Uses of Enchantment: The Meaning and Importance of Fairy Tales, Knopf, New York, 1976

- Butler, Judith, Bodies that matter: On the discoursive limits of "sex", Routledge, London, 1993

- Butler, Judith, Gender Trouble, Routledge, London, 1990

- Calvino, Italo, Fiabe italiane, 3 voll., Torino, Einaudi, 1956

- Calvino, Italo; Lavagetto, Mario, a cura di, Sulla fiaba, Torino, Einaudi, 1988

- Caraffi, Patrizia, Figure femminili del sapere, 2003, Roma, Carocci Editore

- Carter, Angela, The Bloody Chamber and other stories, from Burning your boats, Penguin Books, London, 1995

- Carter, Angela, The Bloody Chamber and other stories, Gollancz, London, 1979

- Carter, Angela, The First and Second Book of Virago Fairy Tales, 2 voll., Virago Press, London, 1991; 1993 
- Carter, Angela, The Passion of New Eve, Virago Press, London, 1982

- Carter, Angela, The Sadeian Woman and the Ideology of Pornography, Pantheon Books, London, 1978

- Cavarero, Adriana, Nonostante Platone. Figure femminili nella filosofia antica, Ombre Corte, Verona, 2009

- Cavarero, Adriana, Tu che mi guardi, tu che mi racconti. Filosofia della narrazione, , Torino, Einaudi, 1997

- Chainani, Soman, Sadeian Tragedy: The Politics of content revisions in Angela Carter's The Snow Child. Marvels \& Tales, Vol. 17, No. 2 (2003), pp. 212-235

- Charles, Casey, Gender Trouble in "Twelfth Night". Theatre Journal. Vol. 49, No. 2 (May, 1997), pp. 121-141

- Cutrufelli, Maria Rosa, L'unità d'Italia: guerra contadina e nascita del sottosviluppo del Sud, Bertani, Verona, 1974

- Dietzman, Sara Jane, En guize d'omme : female cross dressing and gender reversal in four medieval French texts, PhD Dissertation, University of Virginia, 2005

- Estès, Clarissa Pinkola, Donne che corrono coi lupi. Il mito della donna selvaggia, Milano, Sperling \& Kupfer, 1992

- Gilbert, Sandra, and, Susan Gubar, The Madwoman in the Attic: The Woman Writer and the Ninetheenth Century Literary Imagination. New Haven: Yale UP, 1979

- Greimas, Algirdas Julien, Structural Semantics: An Attempt at a Method. trans. Daniele McDowell, Ronald Schleifer, and Alan Velie. Lincoln, Nebraska: University of Nebraska Press, 1983.

- Grimm, Jacob and Wilhelm, The Original Folk and Fairy Tales of the Brothers Grimm, edited by Jack Zipes, Princeton UP, Princeton and Oxford, 2014

- Gubar, Susan, 'The Blank Page' and the issues of Female Creativity. Writing and Sexual Difference. Ed. Elizabeth Abel. Chicago: University of Chicago P, 1982. 7393

- Haffenden, John, Novelists in Interview, New York, Methuen Press, 1985

- Hannon, Patricia, Fabulous Identities: Women's Fairy Tales in Seventeenth-Century France, Amsterdam, Rodopi, 1994

- Irigaray, Luce, Divine Women, Local Consumption, Sidney, 1986. 
- Kingston, Maxine Hong, The Woman Warrior: Memoirs of a Girlhood Among Ghosts, Random House, New York, 1989

- Lavagetto, Mario, Dovuto a Calvino, Bollati Boringhieri, Torino, 2001

- Michelacci, Lara, Ricostruire l'identità, reinventare il passato: La briganta di Maria Rosa Cutrufelli. in Poetiche. Rivista di letteratura, pp. 217-234

- Mieli, Mario, Elementi di critica omosessuale, Milano, Feltrinelli, I ed. 2018

- Orazi, Veronica, "La fanciulla perseguitata: motivo folclorico a struttura iterativa", in "Anaforá". Forme della ripetizione, a cura di I. Paccagnella et al., Padova, Esedra, pp. 77-97, 2011

- Perrault, Charles, Contes de ma mere l'Oye. The Complete Fairy Tales, translated by Christopher Betts, Oxford University Press Inc., New York, 2009, p. 113

- Propp, Vladimir, Morfologia della fiaba, a cura di Gian Luigi Bravo, Torino, Einaudi, 2000

- Rak, Michele, Logica della fiaba: fate, orchi, gioco, corte, fortuna, viaggio, capriccio, metamorfosi, corpo, Milano, Mondadori, 2005

- Raymond, Janice, A Passion for Friends. Toward a Philosophy of Female Affection, Beacon Press, 1986

- Rich, Adrienne, When We Dead Awaken: Writing as Revision, pp. 33-108, from Rich, Adrienne, On Lies, Secret, and Silence. W. W. Norton \& Company, 1995

- Rubin, Gayle, The Traffic in Women: Notes on the 'Political Economy' of Sex, Ismael Books, United, 1975

- Rubin, Gayle, Thinking Sex: Notes for a Radical Theory of the Politics of Sexuality, in Carole Vance, ed., Pleasure and Danger (Routledge \& Kegan, Paul, 1984. Also reprinted in many other collections, including Abelove, H.; Barale, M. A.; Halperin, D. M.), The Lesbian and Gay Studies Reader (New York: Routledge, 1994)

- Selvidge, Lisa, Writing Fiction Workbook, Lulu Enterprises, UK, 2007, p. 78

- Straparola, Giovanni Francesco, The Facetious Nights, trans. W.G.Waters 1894. Scanned original color illustrated editions

- Tatar, Maria, The Annotated Classic Fairy Tales, W. W. Norton \& Company, New York, 2002

- Tatar, Maria, The Hard Facts of the Grimms' Fairy Tales, Princeton University Press, 1987 
- Thompson, Stith, The Folktale, University of California Press, 1977

- Vesselovskij- Sade, La fanciulla perseguitata, 1970, Milano, Bompiani

- Warner, Marina, From the Beast to the Blonde. From Fairy Tales to their Tellers, Vintage, New York, 1994

- Wilson, Sharon Rose, Margaret Atwood's Fairy Tale Sexual Politics, University Press of Mississippi, 1993

- Zipes, Jack, Why Fairy Tales Stick, Taylor \& Francis, 2006

\section{Webliography}


- https://www.pinterest.com/pin/602989837584288249/ (Walter Crane Illustration; figure 1) [last accessed: 21/08/2018]

- https://www.pinterest.it/pin/539306124109021620/ (Gustave Dorè illustration; figure 2) [last accessed: 21/08/2018]

- $\quad$ https://www.pinterest.it/pin/304204149804363785/ (Dulac illustration; figure 3) [last accessed: 21/08/2018]

- https://www.iep.utm.edu/irigaray/ [last accessed: 10/09/2018] 
My sincere and special thanks go to Professor Gerardo Rodriguez Salas, my supervisor, who has been the perfect partner for this challenge. His previous experience and writings on folktales and Angela Carter and his suggestions about essays to consult have represented a precious support for my work. Thank you for your patience and your constructive criticism.

Thanks to Professor Rita Monticelli for her unforgettable classes of Feminist Theory, which were the ultimate gymnasium for the assimilation and deep comprehension of feminist and queer criticism. But most of all, thank you for having put The Passion of New Eve in your course bibliography.

E ora lasciate che mi esprima nella mia lingua madre affinché possa essere compreso totalmente dalle persone straordinarie che fanno parte ogni giorno della mia vita. Inizio dalle persone che hanno fatto parte del mio percorso in questi ultimi due anni. Iniziare questo master non mi ha soltanto formato come studente universitario e come intellettuale, mi ha anche aiutato a comprendere cose di me che non conoscevo o che molto più probabilmente non volevo conoscere, e a capire che non c'è niente di male nell'essere felici e onesti con sé stessi. Semmai dovesse capitare a qualcuno degli studenti e delle studentesse che verranno dopo di me di leggere la mia tesi per farsi un'idea su come procedere con il proprio lavoro, voglio che sappiate che con questa affermazione sarò totalmente onesto: il GEMMA ti cambia davvero, non si tratta soltanto di corsi da seguire e teorie da assimilare, un contesto come questo ti apre gli occhi, ti fa conoscere persone incredibili che nel bene e nel male finirai per amare. Nelle nostre lunghe conversazioni tra amiche abbiamo raggiunto un grado di consapevolezza individuale e reciproca che non $\mathrm{mi}$ era mai capitato di provare prima con nessun altro. Quindi grazie a te, Anna, grazie Valentina, Angie, Giulia, Rebeca, Chiara, per essere state le migliori compagne di viaggio che si potessero desiderare, voglio utilizzare questo spazio per dirvi che non mi importa di cosa succederà, se finiremo per ignorarci, se la Lega prima o poi mi manderà nei lager per gender traitors o se voi finirete a essere handmaids in casa di qualche sostenitore dell'indipendenza padana, tanto vi troverò e faremo parte della resistenza. Non mi interessa se il legame che abbiamo ora sbiadirà negli anni, quello che mi importa è farvi sapere che il lavoro che ho fatto su me stesso in questi due anni non sarebbe stato 
possibile se non ci foste state voi, e che vi voglio bene dall'angolo più remoto del mio cuore, e che in fondo spero ancora nel nostro caffè letterario transfemminista queer.

Nolite te bastardes carborundorum.

Le altre persone che mi sento in dovere di ringraziare, nell'anno domini 2018, le ho conosciute a Granada, e raramente mi è capitato di assistere a una dinamica così bella come quella a cui ho avuto il privilegio di essere partecipe, la formazione di un legame, spensierato e irruento come il nostro, perciò grazie a Francesca, Chiara, Isabella, Valentino, Matteo, Francesco, Nicola per l'anno meraviglioso che mi avete fatto trascorrere e le nostre avventure siculo-napoletano-apulo-romano-emiliano-romagnoleandaluse. Lunga vita al trash. E alla pizza del Sacromonte.

Grazie alla mia famiglia per avermi trasmesso il senso di responsabilità e di dovere, per esserci stata quando avevo bisogno di qualcuno con cui parlare, per non avermi mai voltato le spalle e aver sempre cercato di comprendermi e rispettarmi. Grazie per essere sempre il riparo a cui poter fare ritorno, e per le audiocassette di De André in macchina mentre in estate andavamo al mare. Grazie a Giovanna, per le liti, per le incomprensioni, per tentare di comprendere il mio punto di vista nonostante tutto, per il bene profondo che mi vuoi, per il bene profondo che ti voglio, che tu ci creda o no, per la distanza che mi impegnerò a colmare con la presenza, per Futura.

Grazie a tutti gli amici e le persone care lontane, con cui anche se non riusciamo più a vederci con l'assiduità di un tempo a causa degli accidenti della vita, so di aver creato dei legami perenni.

Grazie a Giuseppe, per essere il mio amico praticamente da tutta la vita.

Grazie a Silvia per essere sempre la mia lettrice più accanita, oltre che l'unica persona al mondo che per farti sentire di essere speciale ti dice che sei un "opale a taglio cabochon".

Grazie a Manel, per quel giorno che mi hai portato al Luna Park del Tibidabo per festeggiare il mio compleanno, e per tutte le altre innumerevoli ragioni che spero tu conosca. Se ti tagliassero a pezzetti il vento li raccoglierebbe. 